\title{
Revisitando casas-grandes e senzalas: a arquitetura das plantations escravistas americanas no século XIX
}

\section{Rafael de Bivar Marquese ${ }^{2}$}

RESUMO: $\bigcirc$ artigo analisa a planta arquitetônica de grandes unidades rurais escravistas do Vale do Paraíba cafeeiro (Brasil), do cinturão algodoeiro de Matanzas-Cienfuegos-Trinidad (Cuba) e do cinturão algodoeiro do Alabama e do baixo vale do Mississippi nos Estados Unidos, todas construídas na primeira metade do século XIX. O foco incide sobre as relações entre os processos produtivos e a disposição das casas de vivenda senhoriais e das moradias escravas. O objetivo é examinar o peso respectivo que a função e a representação arquitetônicas tiveram na conformação desses espaços.

PALAVRAS-CHAVE: Escravidão. Arquitetura de Plantation. Brasil. Cuba. Estados Unidos.

ABSTRACT: This article analyses the architectural plans of the Vale do Paraíba large slave coffee plantations (Brazil), of the Matanzas-Cienfuegos-Trinidad (Cuba) sugar plantations and of the Alabama and lower Mississipi Valley cotton plantations in the United States, all built in the first half of the $19^{\text {th }}$ Century. The focus is cast on the relationship between the productive processes and the disposition of the master's big houses and slave quarters. The aim is to examine the respective weights that the architectural function and representation featured in the disposition of these spaces.

KEYWORDS: Slavery. Plantation Architecture. Brazil. Cuba. United States.

A tradição da casa-grande e as plantations escravistas do Novo Mundo

surgimento da tradição da casa-grande na Europa ocidental do início da ldade Moderna fez parte do mesmo processo histórico que levou à formação das primeiras plantations escravistas do espaço atlântico. Como

\begin{abstract}
1. O texto, originalmente apresentado como conferência ao II Encontro Escravidão e Liberdade no Brasil Meridional (UFRGS, Porto Alegre, outubro de 2005), faz parte de um projeto coletivo mais amplo financiado pela The Getty Foundation.Agradeço as sugestões e os comentários da equipe do projeto (Dale Tomich, Reinaldo Funes, Carlos Venegas, Charles Burroughs, Maria Cecília Winter), bem como os organizadores do encontro em Porto Alegre. Agradeço ainda os comentários de Ulpiano Bezerra de Meneses, Robert Slenes e Silvia Lara.

2. Docente do Departamento de História da Faculdade de Filosofia, Letras e Ciências Humanas da Universidade de São Paulo. E-mail: marquese @usp.br
\end{abstract}


Reinhard Bentmann e Michael Müller demonstraram há mais de trinta anos, a sistematização do movimento arquitetônico que ficou associado ao nome de Andrea Palladio - notabilizado pela tentativa de trazer para o mundo moderno a linhagem das villas romanas do mundo antigo - foi em grande parte uma resposta das elites mercantis venezianas à crise que se abateu sobre a economia de sua república com os descobrimentos marítimos da passagem do século XV para o XVI. Com efeito, a expansão ultramarina portuguesa e espanhola trouxe enorme impacto negativo para a economia veneziana, até então totalmente estruturada em torno do comércio com o Levante. Após 1530, quando ficou evidente que a crise seria persistente, ocorreu a virada decisiva dos interesses das elites mercantis da "Sereníssima" para a chamada terraferma, a vasta planície que servia de retaguarda para o enclave portuário na laguna do Adriático e que vinha sendo ocupada desde o século XIV. A partir da quarta década do século XVI, como parte de um movimento intelectual e social mais amplo denominado villegiatura, a paisagem da terraferma passou a ser dominada por suntuosas villas, que, ao buscarem as tradições arquitetônicas e literárias clássicas, procuravam neutralizar as graves tensões sociais que marcavam a República de Veneza (BENTMANN; MÜLLER, 1975).

$\bigcirc$ quadro histórico que deu origem às villas romanas, no entanto, era profundamente diferente do Vêneto quinhentista. Antes de tudo, pelo simples fato de se tratar de um universo social regido pelo escravismo. Em seu esforço para recompor o mundo clássico, o palladianismo e a villegiatura tiveram que enfrentar um outro obstáculo ainda maior, pois, antes das escavações arqueológicas setecentistas, não havia exemplares arquitetônicos das villas romanas que pudessem ser diretamente observados pelos coevos (GUARINELLO, 1993). A arquitetura das casas de vivenda rurais que apareceu na terraferma veneziana do século XVI, pretensamente baseada nas villas romanas, foi, portanto, muito mais uma tradição inventada do que uma recuperação integral e intocada de modelos clássicos (ACKERMAN, 1990; HOBSBAWM; RANGER, 1984).

No exato momento em que estava sendo criada essa tradição, um esquadro societário análogo ao romano, composto por senhores e grandes massas de trabalhadores escravizados, ressurgia no espaço atlântico. Fruto do alargamento da base geográfica da economia-mundo européia (WALLERSTEIN, 1974), as unidades produtivas açucareiras fundadas pelos europeus nas Canárias e na Madeira, na segunda metade do século XV, guardavam ainda muitos dos elementos que haviam caracterizado a atividade no Mediterrâneo durante a ldade Média, como uma tecnologia rudimentar, adaptada de outros processos produtivos (como o do vinho e do azeite), e uma mão-de-obra mista, com uso apenas parcial de escravos. O ponto de virada veio com a implantação da indústria açucareira em São Tomé e Hispaniola na primeira metade do século XVI e, sobretudo, com a formação da rede de engenhos na costa nordeste da América portuguesa na segunda metade desse século. Na mesma década em que eram impressos na Itália os Quattro Libri dell'Architettura, de Palladio (1570), Bahia e Pernambuco iniciavam o incrível arranque de sua produção escravista de açúcar, com unidades que, em breve, combinariam "especialização na produção de bens para 
exportação", tecnologia avançada, "mão-de-obra exclusivamente escrava e uma posse de terra consolidada" (MILLER, 1997, p. 17).

advento do escravismo de plantation no espaço atlântico e o do palladianismo e da villegiatura na Itália setentrional, enfim, fizeram parte de uma ação mais ampla de recuperação, reconfiguração e projeção do mundo antigo para a modernidade. Palladianismo e escravismo de plantation, contudo, só iriam se cruzar de forma clara e evidente a partir do final do século XVIII. É verdade que, já na segunda metade do século XVII, parece ter havido uma certa leitura de Palladio para o universo dos engenhos na América portuguesa. Todo o quadro pictórico empregado por Frans Post para tratar da paisagem dos engenhos de açúcar de Pernambuco, por exemplo, baseou-se claramente nos princípios do palladianismo, como a disposição da paisagem construída na forma de teatro, localizando-se a casa-grande e a capela no alto da encosta, as instalações produtivas no plano médio e a várzea ao fundo. Sabendo-se, no entanto, que os documentos visuais não podem ser tomados como registros fiéis e neutros de práticas materiais (MENESES, 1996), é possível aventar a hipótese - a ser confirmada com futuras pesquisas arqueológicas - de que essa leitura de Palladio tenha ocorrido antes no campo das representações visuais do que no da prática construtiva dos engenhos.

Seja como for, antes do final dos setecentos, a tradição da casagrande desenvolveu-se bem mais no Velho do que Novo Mundo. A difusão que o palladianismo então encontrou em diferentes lugares da Europa ocidental, como na Inglaterra hanoveriana e na Lombardia habsburga, deveu-se em grande parte às inscrições políticas do ideal da villa, tal como expresso nos Quattro Libri de Palladio e em outros textos da villegiatura, como os de Alvise Cornaro (Discorsi intorno alla vita sobria, 1583-1595) e Vincenzo Scamozzi (Idea dell'archittetura universale, 1615). Afinal, propagava-se nesses textos a visão da villa como uma "pequena cidade", como um mundo fechado, um lugar onde o gentil-homem poderia ser senhor de si, completamente autônomo no governo de sua família e de seus dependentes (BENTMANN; MÜLLER, 1975). O ideal servia tanto aos whigs ingleses, que o empregaram como forma de afirmação contra a "tirania" Stuart, como aos aristocratas e proprietários rurais da Lombardia, onde o palladianismo funcionou como uma arma política contra a dominação da corte vienense (ACKERMAN, 1990; HARRIS, 2003).

Esse caráter político e ideológico do palladianismo, somado à grande adaptabilidade de seu vocabulário estilístico, foram dois dos fatores que, a partir do final do século XVIII, permitiram sua adoção mais sistemática por senhores de escravos do Novo Mundo. Os casos mais notáveis, nesse ponto, certamente são os senhores virginianos George Washington e Thomas Jefferson, proprietários, respectivamente, das famosas plantations de Mount Vernon e Monticello. Construtores de um Estado nacional recém-independente assentado na escravidão negra, Washington e Jefferson pretendiam expressar em suas plantations os ideais de ordem, liberdade e autonomia que serviam de fundamento para seu projeto político (DALZELL JR., 1993). 
De fato, ao longo da primeira metade do século XIX, houve uma nova onda de apropriação do palladianismo pelos senhores de escravos das Américas, relido agora por meio da corrente neoclássica. Em um contexto de expansão acelerada, e em escala global, da economia mundo-capitalista, tal como a ocorrida entre as décadas de 1820 e 1870, as sociedades escravistas do Novo Mundo passaram por profundas alterações econômicas e políticas. Enquanto antigas áreas escravistas, como o Caribe inglês e francês, entraram em crise, outras regiões verificaram notável crescimento, como foi o caso da colônia espanhola de Cuba, do Império do Brasil e dos estados meridionais da República norte-americana (TOMICH, 2004). Nesse movimento, a arquitetura das plantations e as práticas de administração de suas paisagens foram igualmente modificadas. Novas idéias sobre a gestão agrícola e do trabalho foram combinadas com novas modalidades de construção dos espaços de produção e de moradia, que, não raro, inspiraram-se diretamente na tradição inaugurada por Palladio. Para os propósitos deste artigo, importa ressaltar o surgimento de unidades rurais escravistas com plantas inéditas, que guardavam uma relação direta com os quadros políticos que foram então erigidos em cada uma dessas regiões.

Meu objetivo é analisar a planta arquitetônica de algumas das maiores unidades rurais escravistas do Vale do Paraíba cafeeiro (Brasil), do cinturão açucareiro de Matanzas-Cienfuegos-Trinidad (Cuba), e do cinturão algodoeiro do Alabama e do baixo vale do Mississippi nos Estados Unidos, todas elas construídas na primeira metade do século XIX. Convém dizer que os exemplares aqui examinados, dadas suas dimensões, elaboração arquitetônica e força de trabalho que empregaram, constituíram a exceção, e não a regra em suas respectivas regiões. De todo modo, vale lembrar a advertência de John Vlach sobre o peso que, no sul dos Estados Unidos, tiveram essas grandes plantations, de resto válida para Brasil e Cuba. Em suas palavras,

como um lugar tão pouco representativo como a grande plantation veio dominar a autopercepção do sul é um ponto sobre o qual tem havido considerável discussão. Basta dizer aqui que tanto aqueles fazendeiros que possuíam poucos escravos como aqueles que não tinham nenhum ficavam impressionados pelas pródigas plantations habitadas pela gentry, mirando essa classe e suas construções com uma mistura de admiração e inveja. A deferência com a qual eram tratados os grandes planters em todos os condados se relacionava, sem dúvida, às mensagens que eram visualmente expressas no design de suas propriedades, indicações mais do que claras de uma dominação senhorial que requeria, ao mesmo tempo, a submissão do trabalhador negro e a do visitante branco (VLACH, 1993, p. 8).

Tais exemplares arquitetônicos, em resumo, marcaram profundamente a paisagem escravista do sul dos Estados Unidos, de Cuba e do Brasil. Dado o limite de espaço, meu foco incidirá sobre as relações entre os processos produtivos e a disposição das casas de vivenda senhoriais e das moradias escravas na planta das grandes fazendas e engenhos sulistas, cubanos e brasileiros. Pretendo, com isso, examinar o peso respectivo que a função e a representação arquitetônicas tiveram na conformação desses espaços. 
Cabe ainda uma rápida explicação para a escolha do título do artigo. Gilberto Freyre, em uma das obras mais famosas da literatura mundial sobre a escravidão negra nas Américas, adotou como título justamente esses dois espaços de moradia, empregando-os como uma metáfora capaz de sintetizar o conjunto das relações sociais que pretendia apreender. Além de todos os problemas de Casa-grande \& Senzala - já exaustivamente apontados pelos críticos há mais de meio século -, dois em especial chamam a atenção: primeiro, a anulação do tempo histórico; segundo, o completo olvidamento da dimensão do poder expressa nesses espaços de moradia. Daí a necessidade de revisitar, do ponto de vista da arquitetura e do poder, as relações históricas entre casas-grandes e senzalas na paisagem americana.

Processos produtivos, função e representações arquitetônicas

Há um bom tempo os historiadores da arquitetura no Brasil trabalham com a categoria "programa de necessidades" para entender de que modo os espaços construídos são determinados pelos usos funcionais a que se destinam (COSTA, 1941; LEMOS, 1999). Trata-se, sem dúvida, de uma ferramenta bastante útil para compreender as articulações entre os processos produtivos do algodão, do açúcar e do café e a implantação dos edifícios que compunham as fazendas e engenhos do sul dos Estados Unidos, de Cuba e do Brasil. Útil, porém insuficiente. Noutros termos, essas unidades rurais escravistas foram erigidas articulando de modo estreito as preocupações funcionais com os efeitos simbólicos que pretendiam produzir nos diversos grupos sociais nelas envolvidos - senhores, trabalhadores livres, escravos e comunidade externa à plantation. Para demonstrá-lo, é preciso antes de tudo examinar as demandas criadas pelos processos produtivos desses artigos sobre a implantação das fazendas e engenhos.

Começo pelo caso do algodão. $\bigcirc$ artigo foi cultivado para fins mercantis em todas as Américas desde o século XVI, mas, até meados do XVIII, seu valor comercial para as metrópoles foi diminuto. A razão se encontrava, sobretudo, na reduzida demanda européia. A partir do quarto final dos setecentos, com o advento da industrialização, o consumo do produto aumentou substantivamente, o que estimulou diversas regiões do Novo Mundo - como as terras baixas da Carolina do Sul e da Georgia, as Antilhas francesas e inglesas, as Guianas, o Suriname, Maranhão e Pernambuco - a produzirem o artigo. Até a década de 1790, predominou nas plantações americanas o granjeio das variedades do algodão arbóreo de fibra longa, cujo descaroçamento podia ser facilmente realizado por mecanismos (derivados da churka oriental) compostos de dois rolos pequenos postos em paralelo, que se moviam em direções opostas e eram acionados manualmente ou por pedais; o acondicionamento nos fardos, por sua vez, era feito com o próprio peso dos trabalhadores escravos (VELLOSO, 


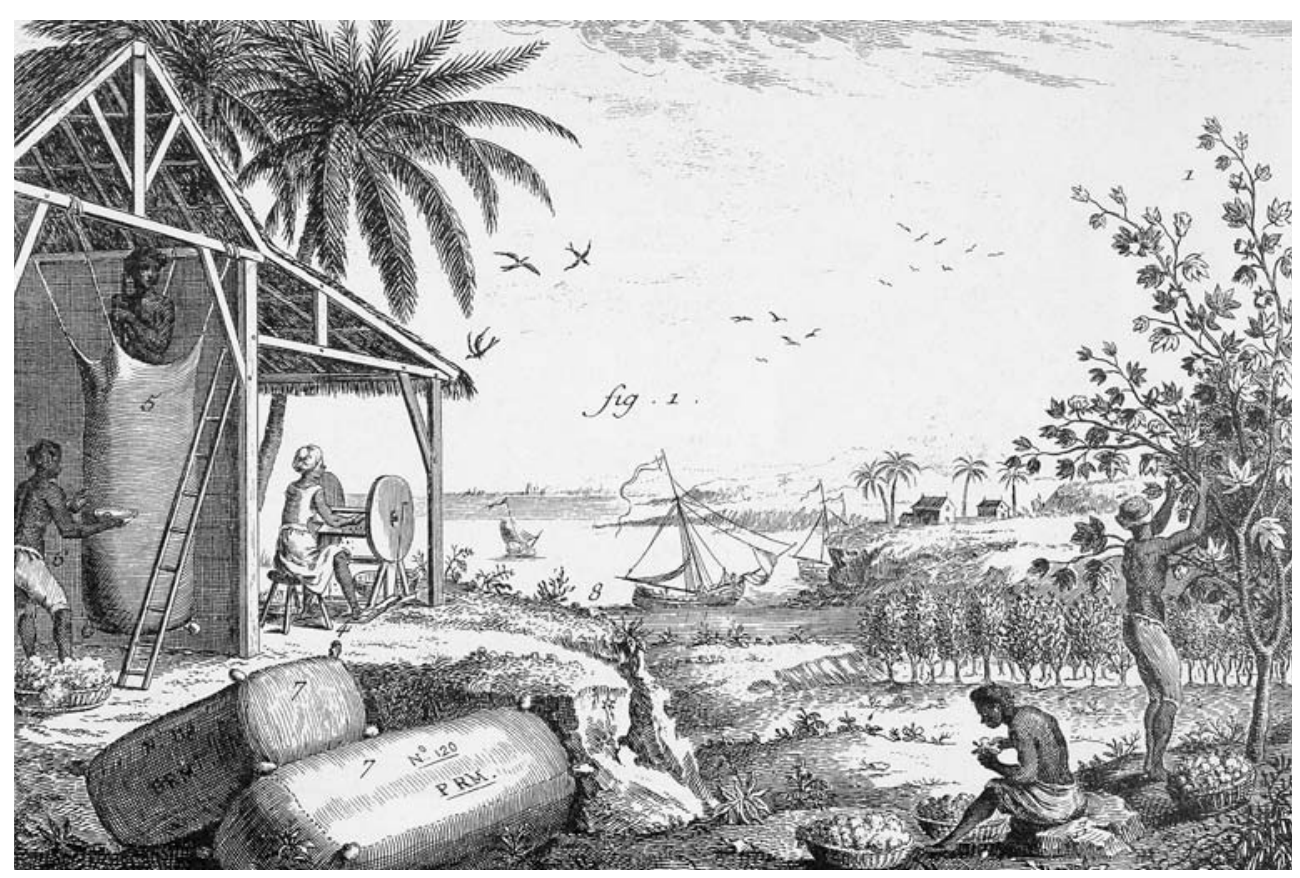

Figura 1 - Representação ideal da produção algodoeira nas Antilhas francesas, década de 1760. Padrão técnico que vigorou em todas as Américas antes da invenção do descaroçador automático de Eli Whitney, em 1793. [ANÔNIMO], Une habitation des Isles de l'Amérique où l'on cultive le coton (DIDEROT, 1969).

1806, p. 5-7) (Figura 1). Até então, o algodão herbáceo de fibra curta não tinha destinação comercial, haja vista as grandes dificuldades para o seu beneficiamento.

Na década de 1780, as maiores regiões produtoras de algodão do Novo Mundo eram Maranhão e Pernambuco (América portuguesa) e São Domingos (Antilhas francesas). Os estados do sul dos Estados Unidos eram, nesse momento, produtores marginais do artigo no mercado mundial. A virada veio na década seguinte, com a revolucionária invenção do descaroçador de Eli Whitney. $\bigcirc$ invento fez parte de um conjunto de esforços sistemáticos para ultrapassar os obstáculos que impediam a conversão do algodão herbáceo de fibra curta em gênero agrícola mercantil. A adoção do novo descaroçador de Whitney na então fronteira escravista do sul - as terras altas da Carolina do Sul e da Geórgia - foi imediata: além de aumentar enormemente a capacidade de beneficiamento do produto, permitindo o plantio do algodão de fibra curta em larga escala, o baixo custo do mecanismo tornou-o disponível a todos os proprietários escravistas das terras altas. A fácil conversão do cultivo do tabaco e do trigo para o do algodão simplificou a transição agrícola para o novo produto (GRAY, 1958, p. 2, 678-686; CHAPLIN, 1993, p. 277-329).

Se a invenção de Whitney superou de forma definitiva o gargalo para o beneficiamento do álgodão de fibra curta, permaneciam as dificuldades para sua colheita. $\bigcirc$ cultivo não apresentava tantos problemas, pois já na década 
de 1790 adotou-se a técnica de plantá-lo em regos, com o uso do arado, e de efetuar a capina com o emprego combinado de arados e enxadas. Por outro lado, as variedades ordinárias de algodão de fibra curta - cultivadas na passagem do século XVIII para o XIX nas terras altas da Carolina do Sul e da Geórgia reduziam em muito a capacidade de colheita por escravo, devido à dificuldade de retirar as cápsulas do vegetal. No Baixo Sul (Alabama, Mississippi, Louisiana), em fins da década de 1800, a criação de variedades híbridas de algodão de fibra curta (valendo-se para tanto de sementes do algodão mexicano) solucionou o problema. Os novos tipos de algodão que passaram a ser cultivados nos estados do sul a partir da década de 1810, mais produtivos e mais fáceis de serem colhidos, tiveram importância considerável no deslanche da economia algodoeira norte-americana, com o notável aumento da produtividade agrícola, tendência que ganhou impulso ainda maior com a ocupação e o cultivo, após 1820, da região da Black Prairie do Alabama e Mississippi, e das terras de aluvião do rio Mississippi (GRAY, 1958, p. 2, 689-690; WHARTENBY, 1977, p. 100-115; WRIGHT, 1978, p. 15-22)

Esse é um ponto fundamental para compreender a arquitetura das plantations algodoeiras no sul dos Estados Unidos. $O$ foco do processo produtivo residia no campo, e não na manufatura. Antes da Guerra Civil, o aumento constante da produção algodoeira norte-americana escorou-se basicamente na ampliação da área de cultivo e no aumento de produtividade da planta e do trabalho escravo nas fainas agrícolas (WHARTENBY, 1977). Após a invenção de Whitney, as únicas inovações ocorridas na etapa de beneficiamento consistiram no melhoramento do mecanismo criado em 1793 e na aplicação de prensas mecânicas para o acondicionamento da fibra nos fardos destinados à exportação. Os edifícios reservados para tanto eram três: 11 o cotton gin, onde ocorria o descaroçamento, em geral um edifício de madeira com dois pavimentos, sendo o superior destinado à alimentação do maquinário com a matéria-prima e o inferior reservado à tração (animal ou à vapor) e à saída da fibra já descaroçada; 2) a prensa, movida por tração animal, com um eixo de madeira capaz de comprimir as fibras em fardos de 180 a 270 quilos; 3) o armazém destinado aos fardos (AIKEN, 1973; VLACH, 1993) (Figura 2). Esses edifícios podiam ser dispostos em qualquer ponto da sede da fazenda. No caso da produção algodoeira, por conseguinte, não houve um programa de necessidades que impusesse de forma rigorosa as demandas do processo produtivo sobre a implantação arquitetônica da unidade rural.

O mesmo não se pode afirmar a respeito do açúcar. Desde o início do século XVII, quando se criaram, em Pernambuco e na Bahia, as linhas gerais do padrão técnico que iria vigorar em todas as plantations americanas até o final do século seguinte, a complexidade do processo de produção impôs um certo programa de necessidades a ser atendido na construção do engenho (GAMA, 1983; WATTS, 1992). Como se sabe, a transformação do sumo da cana em açúcar envolve etapas distintas, porém articuladas. Após o corte, a cana precisa ser moída em menos de 24 horas, sob o risco de inviabilizar a produção. A primeira imposição do processo produtivo sobre a arquitetura dos engenhos, portanto, derivou desse elemento. Houve, desde o século XVII até o 


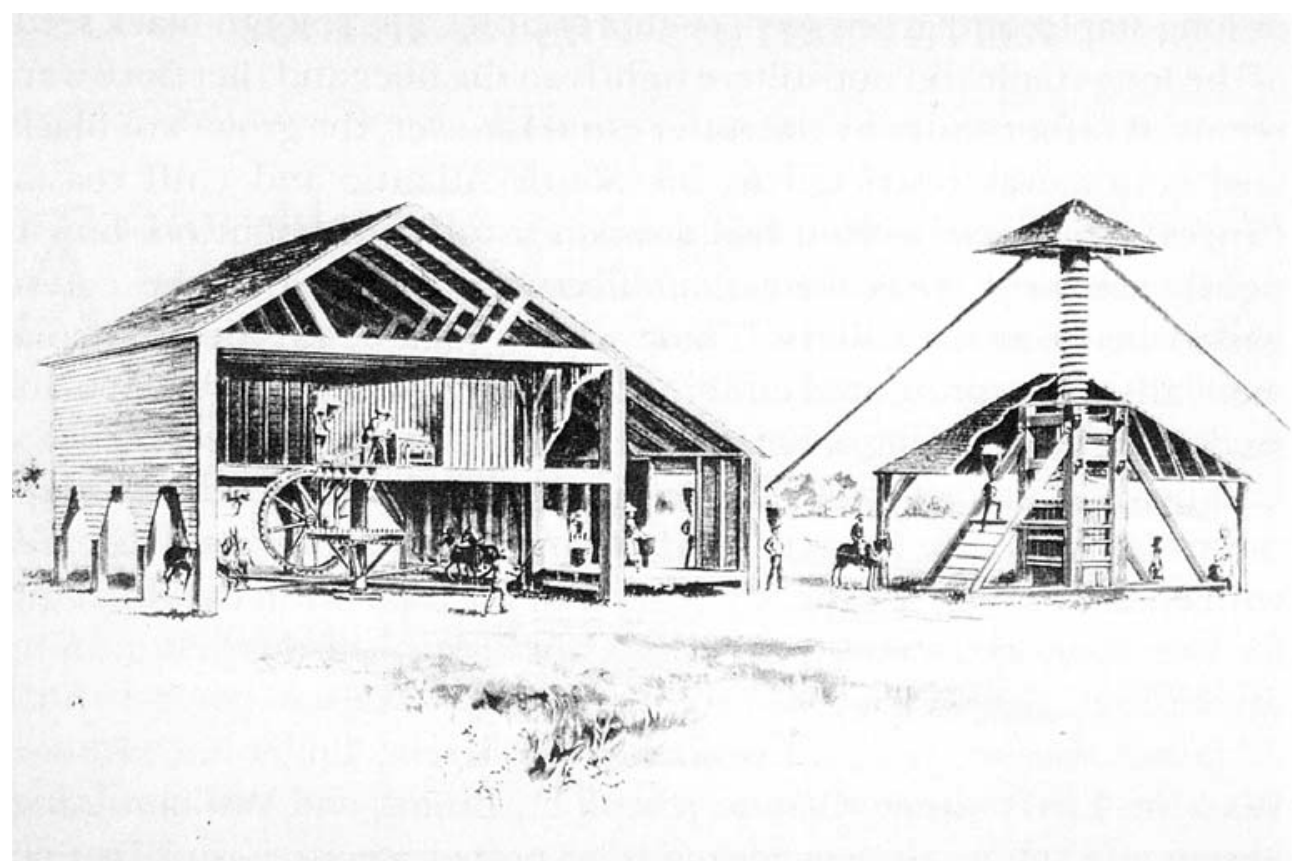

Figura 2 - Cotton Gin e prensa mecânica. Ilustração em TOMPKINS, D. A. History of Mecklenburg County and the City of Charlotte, 1903 (Apud AIKEN, 1973).

presente, uma relação estreita entre os meios de transporte disponíveis e a extensão e distância dos canaviais em relação à fábrica.

Mas não apenas isso. Antes do século XIX, o engenho de açúcar teve o caráter de manufatura orgânica. Conforme indicou a análise de Marx sobre esta base técnica, a proporcionalidade matemática existente entre cada uma das atividades a serem desempenhadas só permitiria a ampliação da escala de produção por meio da multiplicação simétrica de todas as etapas do processo produtivo, com seu respectivo número de trabalhadores (MARX, 1990, v. I, p. 280-28 1). Foi o que ocorreu nas plantations açucareiras dos séculos XVII e XVIII. A quantidade de cana a ser plantada era determinada pela capacidade de produção do engenho, que, por sua vez, obedecia à correlação entre capacidade de esmagamento das moendas, de processamento do caldo no terno das caldeiras e de purificação dos pães de açúcar na casa de purgar. $\bigcirc$ equilíbrio existente entre essas fases significava que, caso fosse adotada uma mudança em uma determinada etapa, todo o processo teria que ser revisto para atender à proporcionalidade que regia o conjunto (CASTRO, 1976).

Em que pesem algumas propostas surgidas em fins do século XVIII, como a de Jacques-François Dutrône para São Domingos (1790), a arquitetura dos engenhos de açúcar do Novo Mundo foi relativamente uniforme durante todo esse período. Moenda e casa das caldeiras faziam parte de uma única edificação ou eram inscritas em construções contíguas. Nos engenhos da América portuguesa e das Antilhas francesas - que produziam açúcar branco e não 
apenas açúcar bruto (como nas Antilhas inglesas) -, a casa de purgar constituía um edifício à parte. Por fim, no caso das moendas movidas à água ou vento, havia uma outra determinação, qual seja, a da proximidade das fontes de energia ${ }^{3}$.

A imposição das necessidades do processo produtivo açucareiro sobre a planta arquitetônica das unidades rurais escravistas acentuou-se ainda mais após 1830, com a revolução tecnológica ocorrida no setor. Nas Américas, isso se deu sobretudo em Cuba e, em menor escala, no Delta do Mississippi. Quebrando com o caráter de manufatura orgânica, o engenho de açúcar adquiriu nessas regiões o estatuto de verdadeira indústria no campo. A moagem, o cozimento e a purificação foram, então, profundamente transformados. As novas moendas horizontais, construídas com ferro fundido e movidas a vapor, ampliaram em muito a capacidade de extração do sumo da cana. Essa inovação era compatível com o padrão técnico manufatureiro anterior, mas em contrapartida exigia a multiplicação do número de ternos de caldeiras abertas e a ampliação substancial nas dimensões da casa de purgar, o que tornava ainda mais complicados os controles técnicos do processo produtivo (Figura 3). A solução para o problema veio com as caldeiras a vácuo, que aumentavam enormemente a produtividade do engenho, garantiam um controle técnico preciso sobre o cozimento, e reduziam em muito a demanda de trabalho e combustível, pois aproveitavam a energia a vapor que era gerada para movimentar a moenda. No que se refere ao preparo final do produto, as centrífugas eliminaram o difícil e prolongado processo de purga necessário para a cristalização do açúcar (FRAGINALS, 1987; SITTERSON, 1973) (Figura 4).

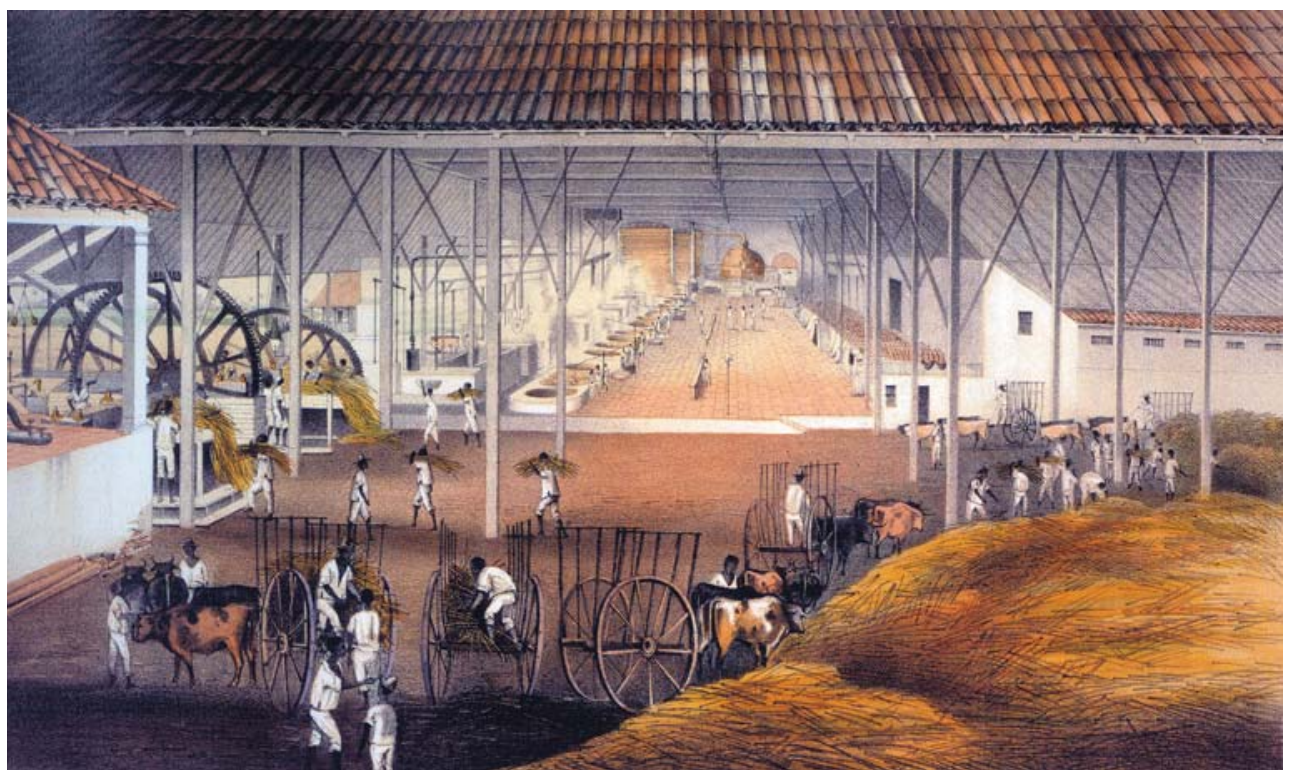

Figura 3 - Eduardo Laplante, Casa das caldeiras do engenho El Progreso (detalhe), litografia (CANTERO; LAPLANTE, 1857).
3. Esse conjunto relativamente uniforme foi registrado à exaustão pela iconografia coeva.Ver, a respeito, MARQUESE, 2002. 
Tudo isso implicou a revisão profunda da planta arquitetônica dos engenhos. Criou-se a necessidade, antes de qualquer coisa, de um enorme alargamento da área de cultivo. Em regiões já densamente ocupadas por uma rede estabelecida de engenhos, como nas colônias inglesas e francesas no Caribe ou no Recôncavo baiano, esse ponto representou considerável obstáculo para a inovação. Em Cuba, pelo contrário, havia amplas reservas de terra virgem no interior do território. A construção, a partir de 1837, da malha ferroviária cubana viabilizou o estabelecimento de engenhos afastados dos portos marítimos. As ferrovias, além de diminuírem os custos de transporte dentro da ilha, permitiram a ampliação da escala de produção das unidades açucareiras, pois, dentro das maiores plantations, a construção de trilhos facilitava e acelerava o transporte de cana para as moendas (GARCÍA; ZANETTI, 1998). A combinação do emprego das moendas horizontais movidas a vapor, das caldeiras de múltiplo efeito a vácuo, das centrífugas e das ferrovias deu origem aos engenhos açucareiros completamente mecanizados de Cuba, que passaram a dominar a paisagem até então desocupada no interior da região centro-ocidental da ilha. As unidades que foram aí erguidas obedeciam em grande parte às demandas funcionais criadas pelo novo padrão técnico da indústria açucareira, adotando um modelo de implantação arquitetônica inédito na história do produto (TOMICH, 2005a) (Figura 5).

Tal como o açúcar, a produção de café requeria certos procedimentos que condicionavam de forma decisiva a construção da fazenda. No entanto, no que se refere à complexidade do beneficiamento, a cafeicultura é bem mais próxima da produção algodoeira do que da fabricação do açúcar, pois se trata de um processo físico, e não químico. O beneficiamento do café consiste apenas na separação da semente dos dois invólucros que a revestem, a polpa e o pergaminho. $\bigcirc$ método que os árabes - primeiros produtores do artigo - haviam

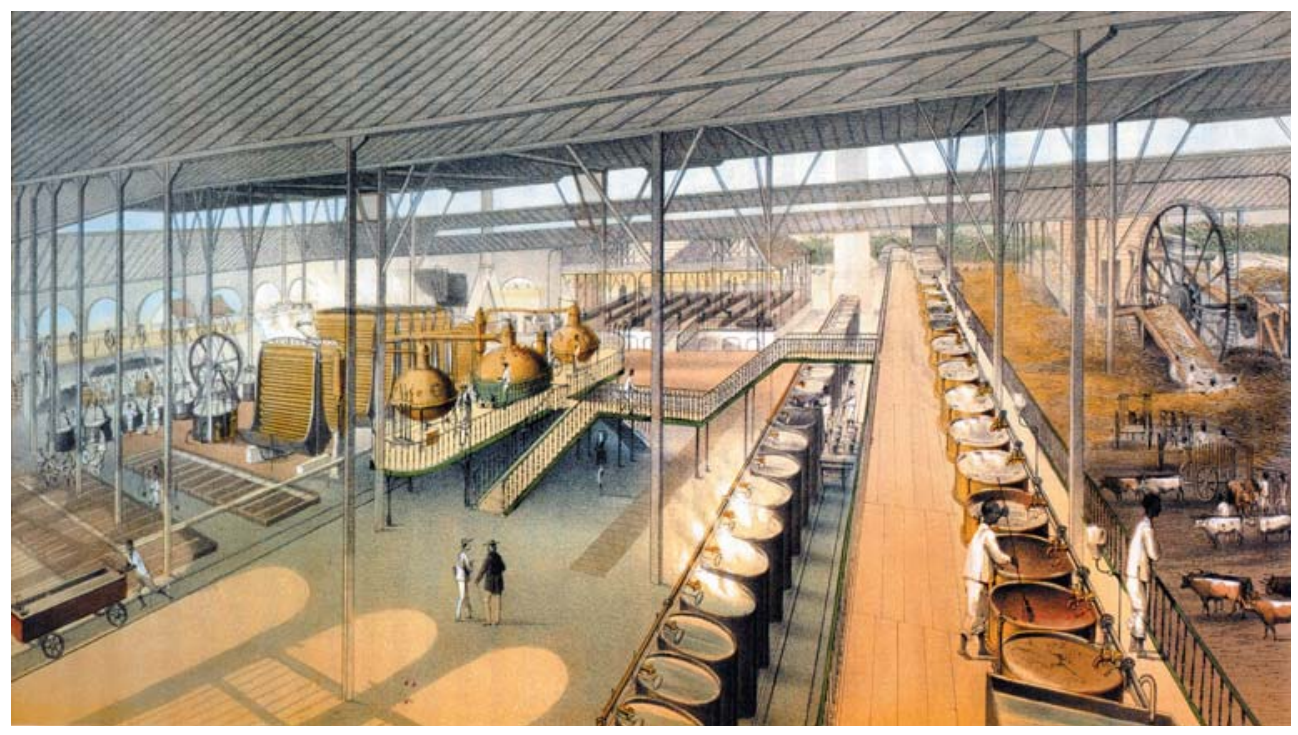

Figura 4 - Eduardo Laplante, Casa das caldeiras do engenho Flor de Cuba, litografia (CANTERO; LAPLANTE, 1857). 


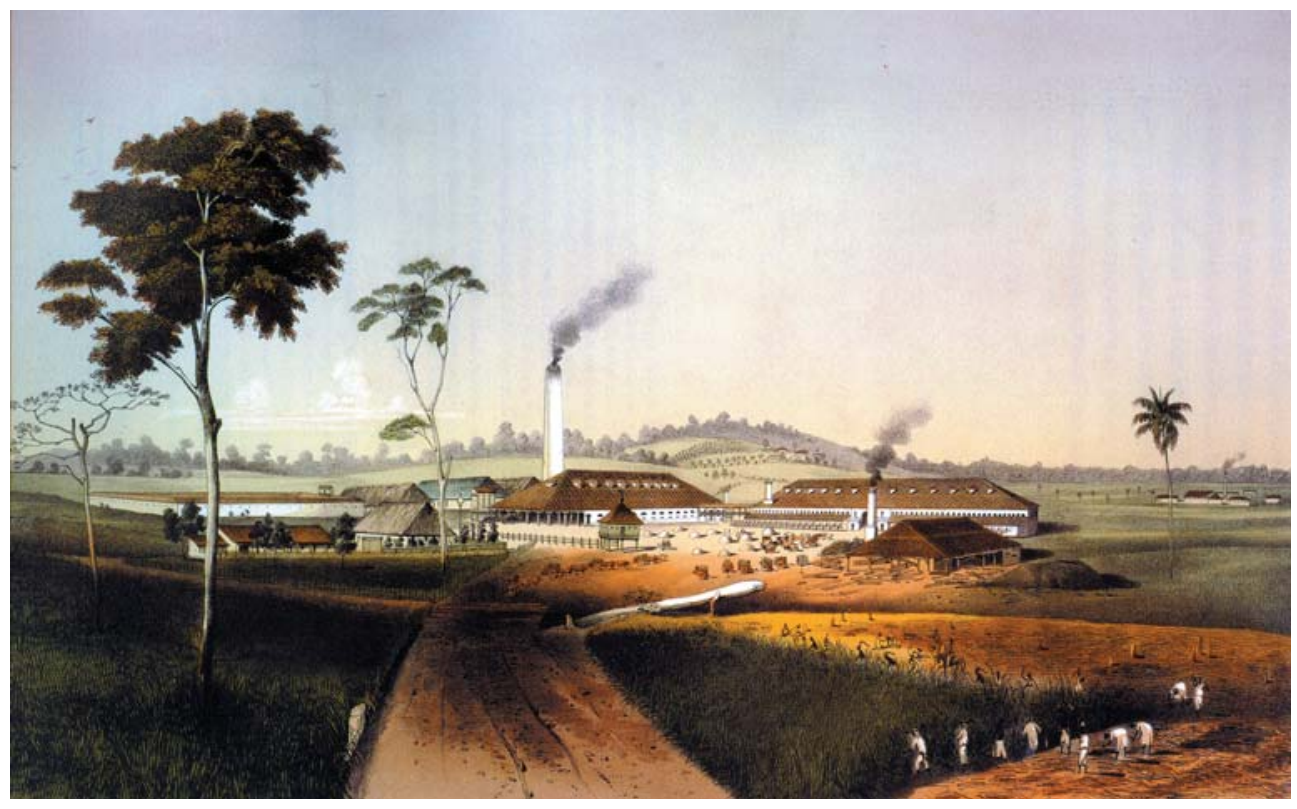

Figura 5 - Eduardo Laplante, Vista do engenho Santa Teresa, 1857, litografia (CANTERO; LAPLANTE, 1857).

adotado para tanto era deixar os frutos maduros secarem por um longo tempo, em panos dispostos no chão e expostos ao sol, até o ponto em que a polpa e o pergaminho fossem facilmente retiráveis em pilões manuais (VELLSO, 1800). Quando, na virada do século XVII para o XVIII, os poderes coloniais europeus passaram a produzir o artigo, foram introduzidas modificações importantes, visando, em especial, ao aumento na escala da produção. Isto ocorreu sobretudo com o sucesso da aclimatação do arbusto na América. Na segunda metade do século XVIII, ocasião em que as Antilhas francesas se tornaram a maior produtora mundial do gênero, criou-se um conjunto de normas técnicas que, em suas linhas gerais, é até hoje seguido por uma parte considerável dos produtores globais.

Esse padrão pode ser observado no trabalho de P. J. Laborie, um grande produtor escravista de café de São Domingos. Laborie foi um daqueles senhores que, no curso da revolução escrava na década de 1790, apoiaram a invasão inglesa da colônia francesa como meio para restabelecer a ordem escravista. Para tanto, redigiu, com base em sua experiência de cafeicultor, o manual The Coffee Planter of Saint Domingo, destinado a guiar os eventuais investidores ingleses no processo de reconstrução da economia escravista da colônia. $\bigcirc$ projeto de Laborie foi derrotado com a vitória das tropas de exescravos, comandadas por Touissaint l'Ouverture, mas seu manual persistiu como a principal referência agronômica sobre o assunto por todo o século XIX.

O tratado foi dividido em quatro capítulos, que abordaram a escolha e preparo dos terrenos para o plantio do café, a construção e distribuição dos edifícios, a cultura e processamento dos grãos e, por último, a administração dos escravos. Para nossos fins, importa salientar de que modo as técnicas 
prescritas por Laborie determinavam a implantação da unidade rural. $\bigcirc$ método por ele recomendado, dada a alta pluviosidade caribenha, era o que por lá se denominava "preparação em casca", conhecido no Vale do Paraíba como "via úmida". Neste método, a polpa dos frutos era imediatamente retirada após a colheita por uma máquina despolpadora acionada por energia hidráulica; envolvidos apenas pelo pergaminho, em seguida os grãos eram lavados durante 24 horas em tanques com água corrente, com o duplo propósito de tirar a goma das sementes e de separar os grãos maduros dos cochos que, ao serem colocados nesses tanques, subiam à superfície - estes grãos, apartados dos maduros, davam posteriormente um café de inferior qualidade. Após a lavagem, os grãos em pergaminho eram levados aos terreiros (ou plataformas de secar, nome que thes era dado nas Antilhas francesas), e, quando completamente secos, procediase à retirada final do pergaminho nos moinhos de descascar (no caso, em um mecanismo que, no Brasil, seria conhecido como carretão ou ripes), encerrandose o processo com a escolha dos grãos e o seu ensacamento (LABORIE, 1798).

Dois pontos se destacavam nessas técnicas: 1) a importância fundamental do abastecimento constante de água para a movimentação dos mecanismos de beneficiamento e lavagem dos grãos; 2) a centralidade dos terreiros. A rigor, pelas pranchas que apresentavam algumas das mais eficientes plantations cafeeiras de São Domingos, nota-se facilmente como o terreiro gerava o conjunto arquitetônico da fazenda (Figura 6).

Após o colapso da produção de São Domingos com a vitória da revolução escrava, Brasil, Cuba e Java herdaram a posição da antiga colônia

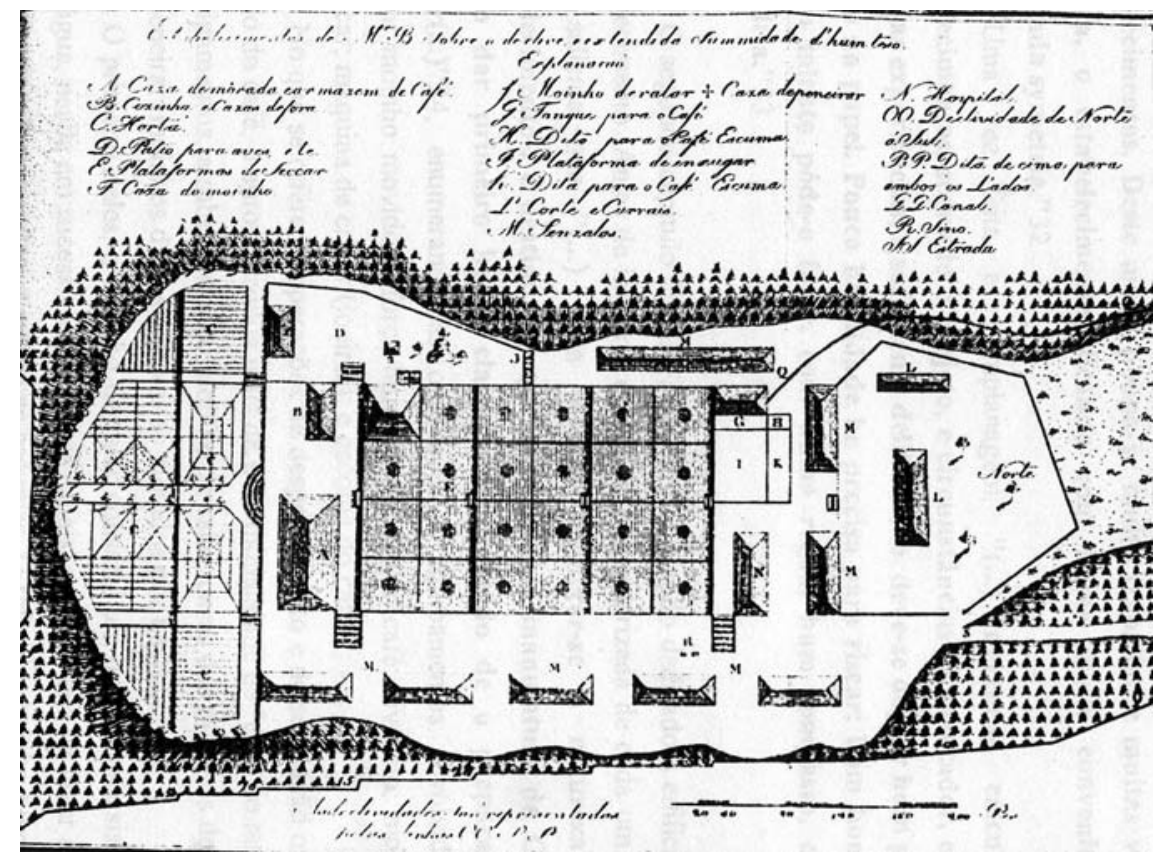

Figura 6 - Planta arquitetônica de uma habitation cafeeira de São Domingos, anterior à Revolução de 1791 (LABORIE, 1798). 
francesa no mercado mundial do artigo. A partir da década de 1830, com o deslanche da cafeicultura escravista no Vale do Paraíba, essa posição coube exclusivamente ao Brasil (VALVERDE, 1985). Por aqui, entretanto, houve algumas alterações no que se refere à base técnica da produção, tanto na esfera agrícola como na manufatura. $\bigcirc$ que nos interessa é a segunda parte. Entre as décadas de 1830 e 1860, o processo de beneficiamento adotado por praticamente todos os cafeicultores do Vale do Paraíba foi o da "via seca", que consistia na secagem dos frutos colhidos em terreiros de chão batido lapós 1850, não raro asfaltados ou ladrilhados) até o ponto em que as polpas estivessem completamente secas. A separação da polpa e do pergaminho ocorria num engenho de pilões - mecanismo que reunia quatro pilões movidos a água num só conjunto (Figura 7) - , tendo, por vezes, ventiladores unidos ao eixo da roda para limpar a poeira originada com a quebra dos revestimentos dos grãos do café; em seguida, o grão iá limpo ia para a casa da escolha, após o que o café estava pronto para ser ensacado e enviado ao mercado (AGUIAR, 1836, p. 15-17).

A despeito dessas alterações, o terreiro - compreendido na documentação coeva como o centro do "quadro da fazenda" - permaneceu como a forma geradora do conjunto arquitetônico cafeeiro (CARRILHO, 1994, p. 120). O principal manual agrícola do Vale do Paraíba oitocentista, a famosa

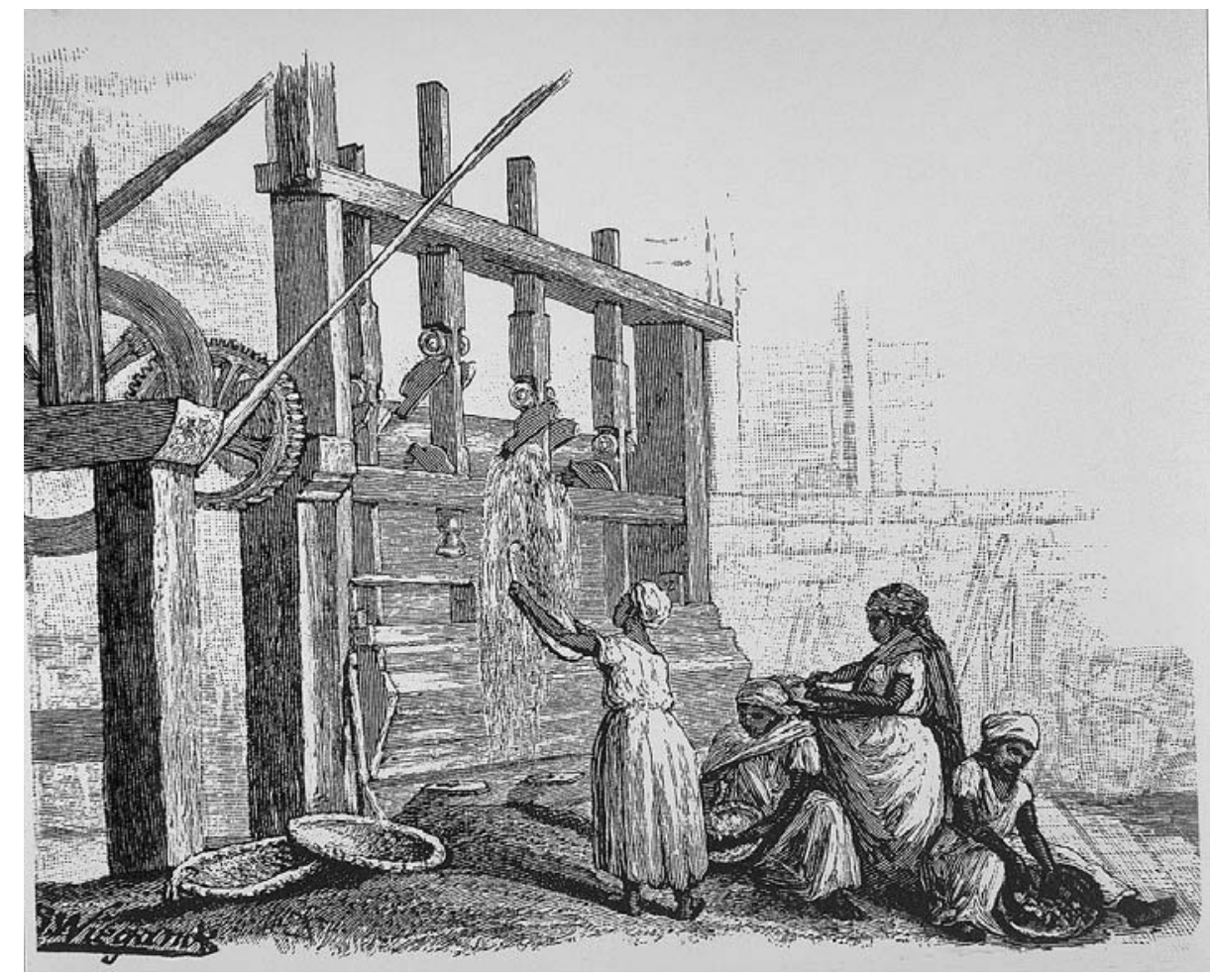

Figura 7 - Bateria de pilões, região de Entre-Rios, RJ. J.B. Wiegandt, 1878, xilogravura (SMITH, 1878). 
Memória, do barão do Paty do Alferes, reconheceu isso de modo muito evidente. Ao fornecer as instruções para a construção de uma fazenda de café, escreveu Lacerda Werneck:

[...] apenas achado o lugar para sentar as máquinas, que, se for possível, devem ficar no quadro da fazenda, tirará ou mandará tirar a planta, com a designação da casa de moradia, de todas as máquinas que forem necessárias, de paióis e armazéns, de cavalariças e senzalas para a moradia dos pretos (WERNECK, 1985, p. 57).

Mesmo com os melhoramentos da segunda metade do século XIX, como o emprego do maquinário Lidgerwood, a construção de terreiros asfaltados e ladrilhados ou a adoção da "via úmida" de beneficiamento, não houve mudança nessas demandas construtivas (Figuras 8 e 9). No caso da cafeicultura brasileira, portanto, a inovação técnica não se traduziu em revisão radical da implantação arquitetônica, tal como ocorreria com a produção açucareira.

Do que foi exposto até o momento, é possível depreender que as exigências de processos produtivos como os do açúcar e o do café criaram um claro programa de necessidades para a construção de engenhos e fazendas, o que em absoluto significa afirmar que responderam sozinhas pela implantação dessas unidades. Outras escolhas estiveram em jogo, mesmo para fazendas e engenhos que seguiam um padrão técnico análogo ou que produziam artigos distintos. Uma rápida comparação entre plantations das regiões examinadas servirá para comprová-lo.

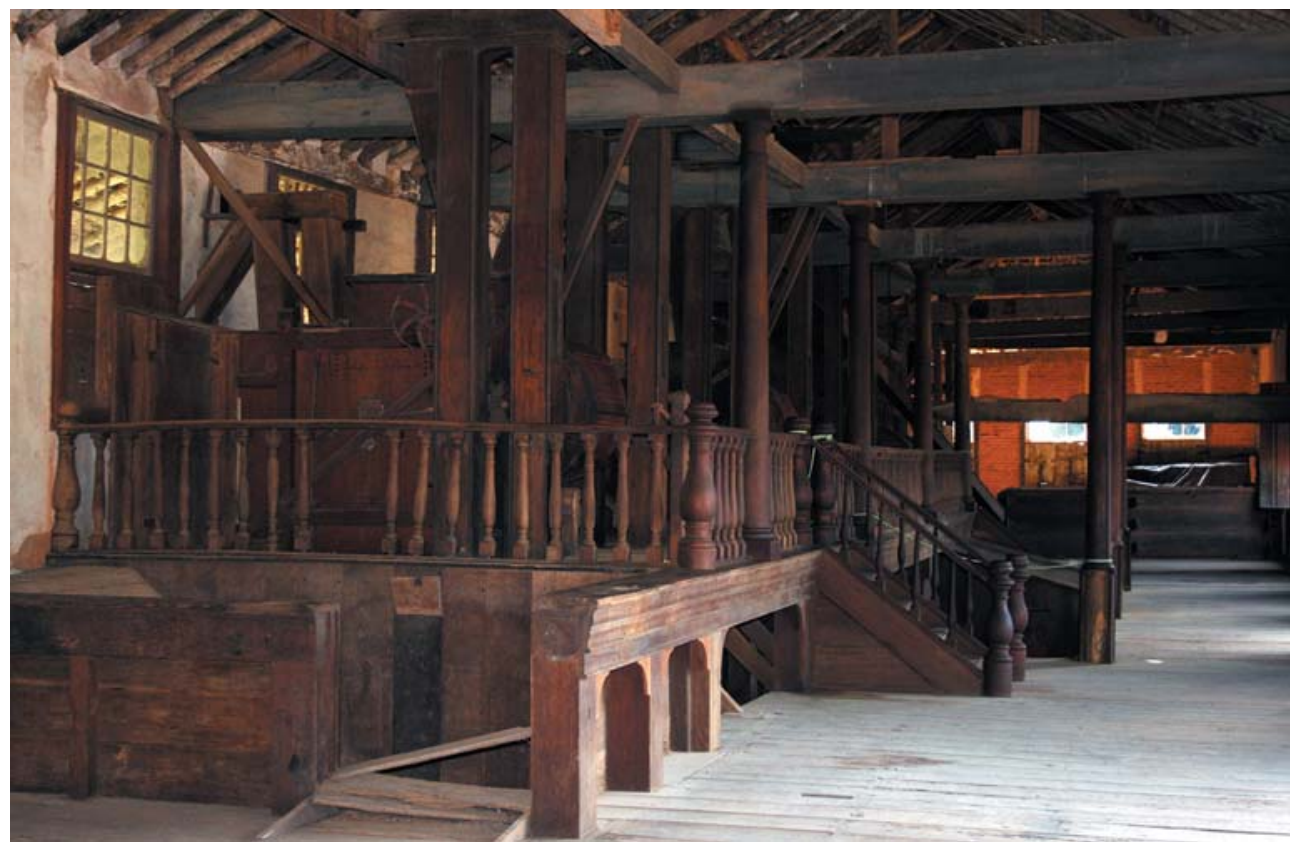

Figura 8 - Maquinário Lidgerwood, fazenda Flores do Paraíso, Rio das Flores, RJ, julho de 2005, fotografia de Maria Cecília Winter. 


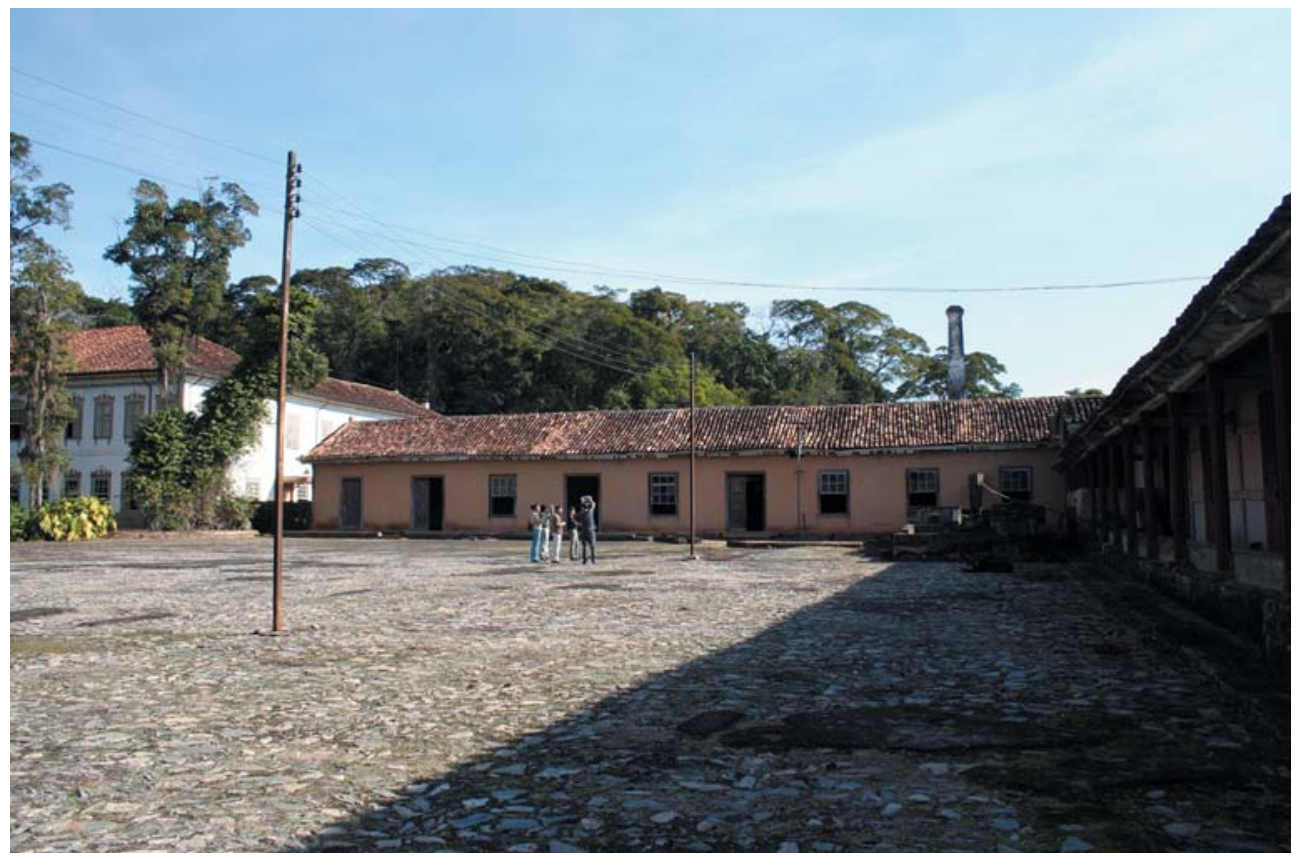

Figura 9 -Terreiro e engenho, fazenda Flores do Paraíso, Rio das Flores, RJ, julho de 2005, fotografia de Maria Cecília Winter.

Tome-se, em primeiro lugar, o exemplo da habitation cafeeira de São Domingos, veiculado por Laborie, e um esquema de implantação da fazenda Boa Vista (Bananal, Vale do Paraíba paulista), feito a partir de um óleo de Georg Grimm. Tanto em um caso como em outro, o terreiro ocupa posição central no conjunto arquitetônico. Todavia, enquanto na habitation de Laborie a casa de vivenda se localiza fora de seu eixo central e as senzalas ocupam apenas uma de suas faces (Figura 6), na fazenda Boa Vista a casa de vivenda - monumental, diga-se de passagem - não só ocupa o eixo central do terreiro como o partido arquitetônico obedece claramente ao modelo em U proposto por Palladio, conjugando-o com duas senzalas em quadra, uma defronte e outra atrás da casa de vivenda (Figuras 10 e 1 1). Um segundo exemplo pode ser buscado na Louisiana e em Cuba. A plantation Uncle Sam e o ingenio Manacas tinham o mesmo padrão técnico, isto é, eram engenhos semimecanizados, que compatibilizavam o emprego de moendas horizontais a vapor com ternos de caldeiras abertas (Figuras 12 e 13). No que se refere à implantação arquitetônica, entretanto, a Uncle Sam era muito mais parecida com as plantations algodoeiras do sul dos Estados Unidos do que com suas equivalentes açucareiras em Cuba.

Para entender essas diferenças, é necessário recorrer a uma chave interpretativa que não se limite à mera explicação funcional. Em outras palavras, atentar para os elementos de representação mobilizados na ordenação dos espaços de produzir e de morar dessas plantations pode ajudar a compreendêlas devidamente. No que se segue, apresento em poucas páginas um esquema geral de interpretação dessas relações em grandes fazendas e engenhos do sul 


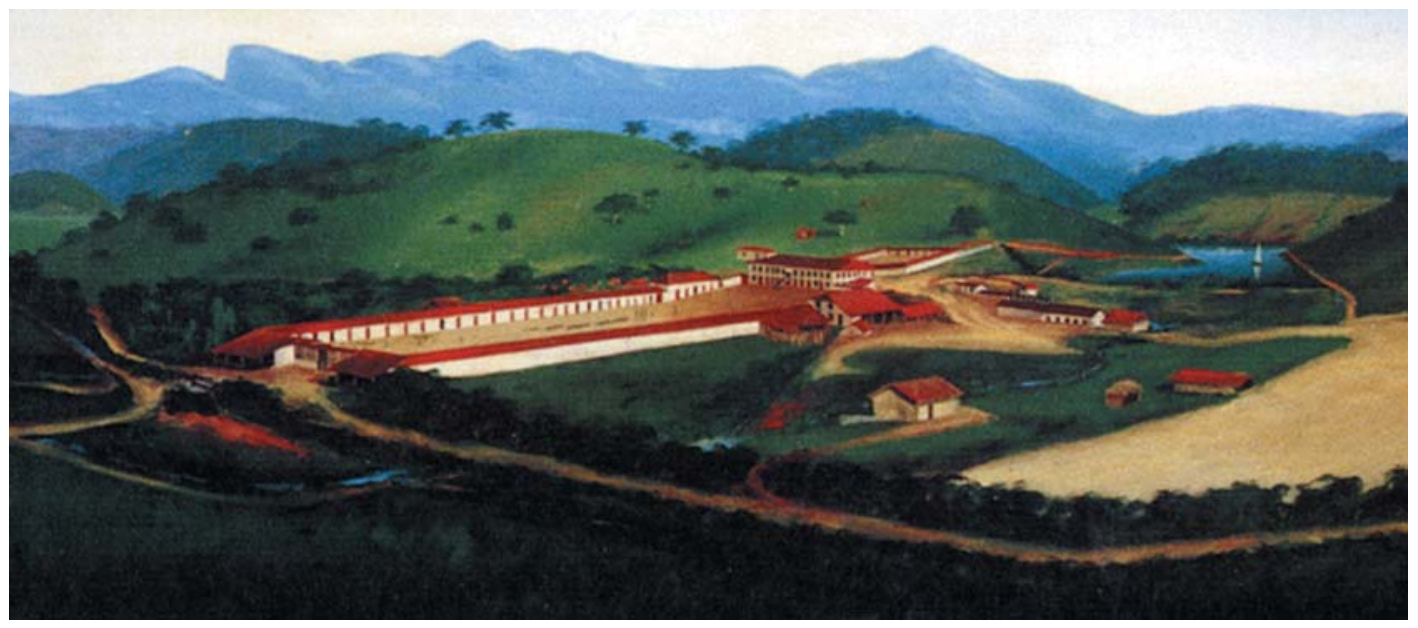

Figura 10 - Georg Grimm [atribuição], Fazenda Boa Vista (detalhe), Bananal, SP, óleo sobre tela, ca. 1880, 74cm x 144cm (SETUBAL, 2004, p. 160).

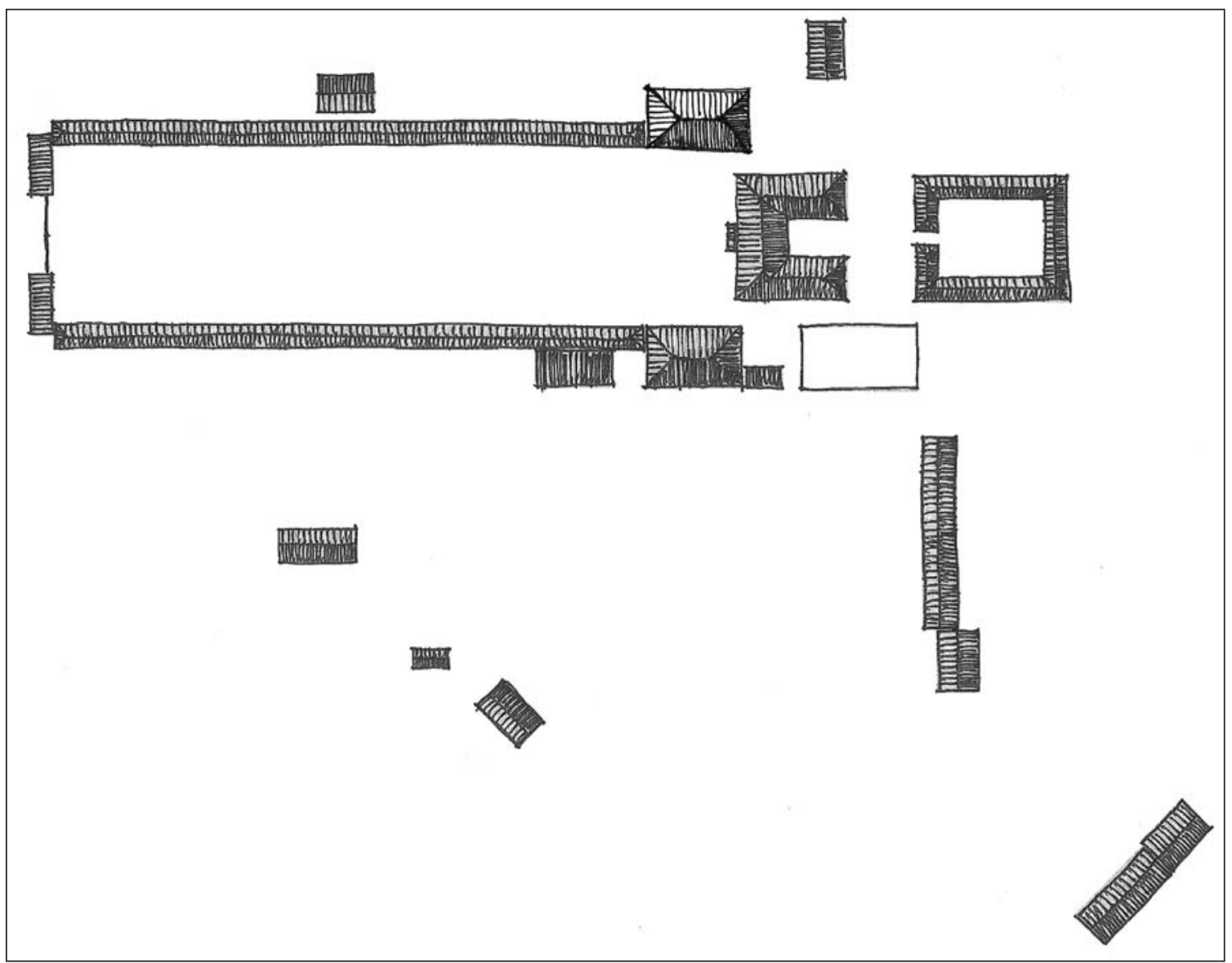

Figura 11 - Osmar Cassiano Gomes Jr., Fazenda Boa Vista, 2005, planta baixa. 


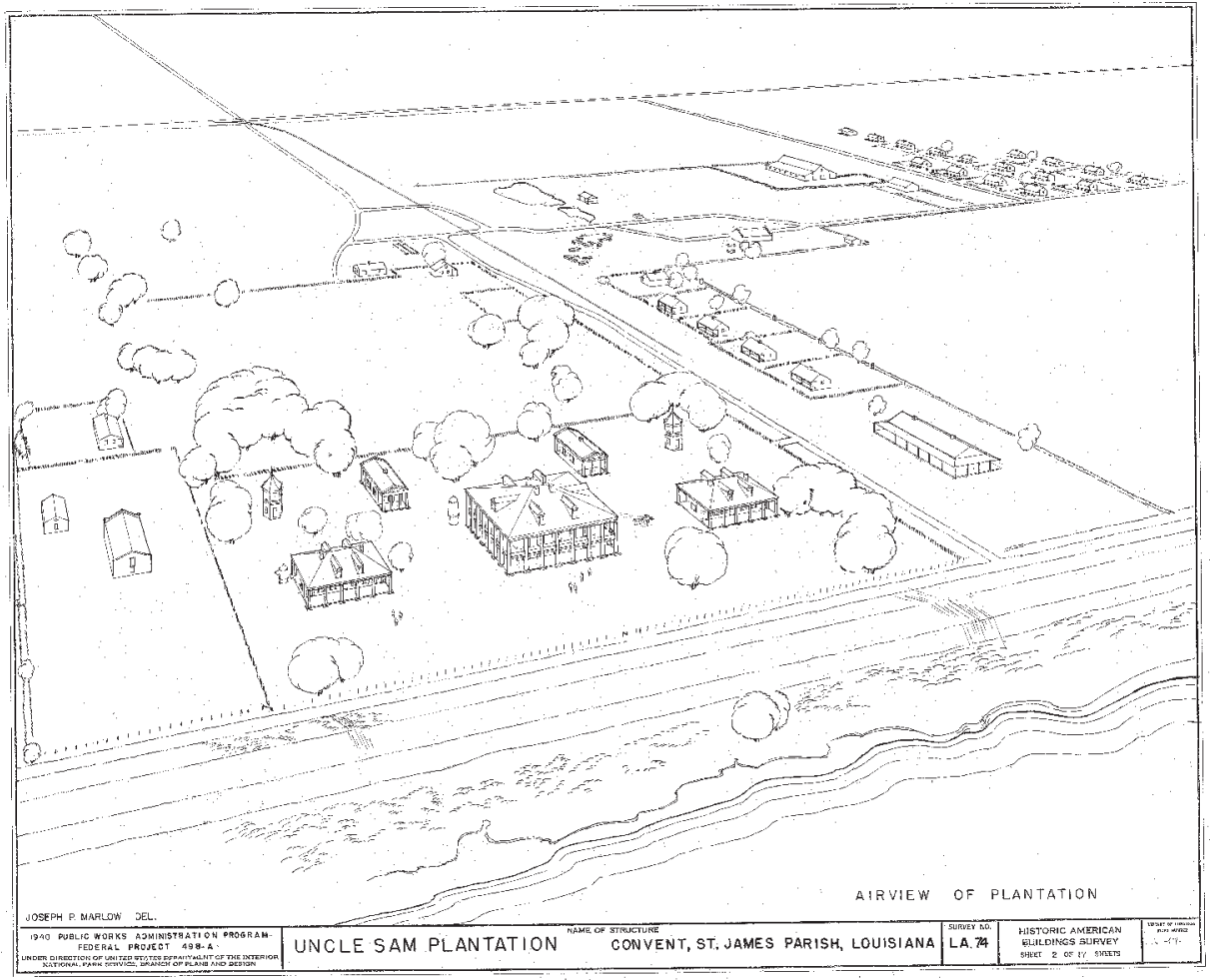

Figura 12 - Vista a vôo de pássaro, plantation Uncle Sam, Lovisiana. Coleção Historic American Buildings Survey da Biblioteca do Congresso, Washington, D.C. (cortesia da Prints and Photographs Division da Biblioteca do Congresso, EUA).

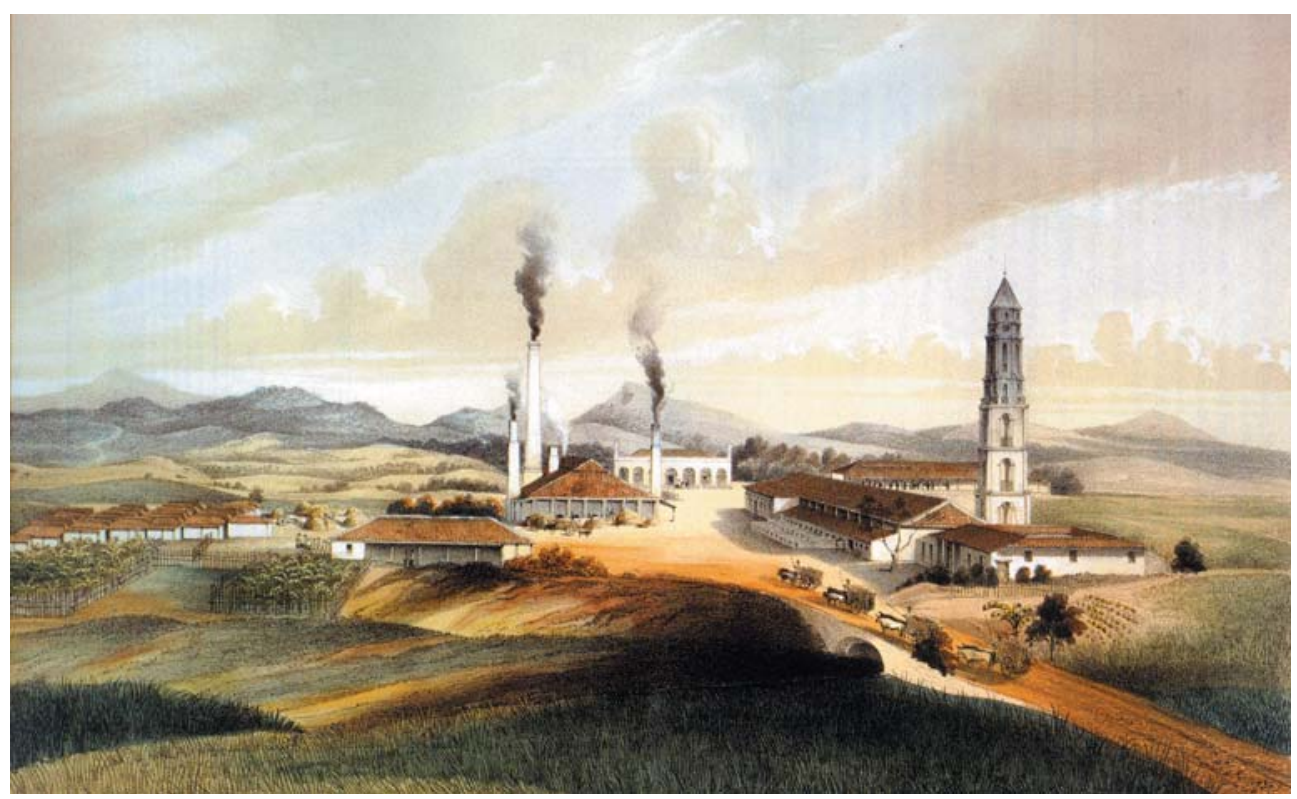

Figura 13 - Eduardo Laplante, Vista do engenho Manacas, litografia (CANTERO; LAPLANTE, 1857). 
dos Estados Unidos, de Cuba e do Brasil, que se apropriaram de elementos particulares da tradição do palladianismo e do vocabulário estilístico do neoclássico, reconfigurando-os conforme os condicionamentos locais, isto é, de acordo com as sociedades escravistas e os quadros políticos a que pertenciam.

O sul dos Estados Unidos e o republicanismo jeffersoniano

Retomemos a penúltima imagem que foi apresentada (Figura 12). Trata-se de um desenho a vôo de pássaro da plantation Uncle Sam, feito nos anos 1940. Localizada no Delta do Mississippi, essa propriedade pertencente a Samuel Faggot foi erguida na segunda metade da década de 1830. Em meados do século, sua unidade açucareira semimecanizada movida a vapor contava com cerca de 165 escravos (VLACH, 1993, p. 191). A casa de vivenda, de inspiração neoclássica, era secundada simetricamente por duas garçonnières, dois escritórios e dois pombais, e localizava-se logo na entrada da propriedade, defronte ao rio Mississippi. As moradias dos escravos estavam dispostas em dois locais distintos. Uma primeira fileira de senzalas, que se iniciava com a enfermaria, encontrava-se à esquerda da casa senhorial, ao passo que um segundo agrupamento de moradias, também enfileiradas, ficava bem ao fundo da sede da plantation. Em posição transversal entre os dois conjuntos de senzalas, assentavam-se as instalações produtivas - moendas, caldeiras, armazéns.

Sua implantação, portanto, separava de forma nítida os espaços de moradia de senhores e escravos. A Uncle Sam tinha uma semelhança muito acentuada com outra plantation açucareira do Delta do Mississippi, a Evergreen, que, até recentemente, mantinha de pé suas senzalas oitocentistas. A casa de vivenda localizava-se na entrada da plantation e se encontrava voltada para o rio, ao passo que a fileira de casebres escravos ficava à sua esquerda, nitidamente separada da casa senhorial (Figuras 14). Enquanto a casa de vivenda atendeu ao revival grego corrente no sul dos Estados Unidos a partir da década de 1820 (Figuras 15 e 16), as senzalas geminadas - cada qual destinada a duas famílias escravas - foram construídas seguindo rigorosamente as prescrições da teoria administrativa coeva (Figura 17), isto é, enfileiradas, sombreadas, uniformes em tamanho e aparência, providas de janelas e varandas, erigidas em madeira, assoalhadas, elevadas a dois pés de altura do chão, com chaminés de pedra e tijolos (MARQUESE, 2004, p. 361-362).

Uncle Sam e Evergreen, além de serem da mesma região, produziam um mesmo artigo. A plantation Thornhill, por sua vez, ficava na Black Prairie algodoeira do estado do Alabama. Construída entre 1833 e 1835, às vésperas da Guerra Civil empregava 156 escravos. Como se pode depreender de uma elevação frontal da casa de vivenda feita um século após sua construção, seu estilo combinava seis colunas jônicas - um aporte oitocentista - com um risco de estilo georgiano, típico da Virgínia setecentista (Figura 18). Ainda que o vocabulário fosse distinto, a implantação arquitetônica era praticamente igual 


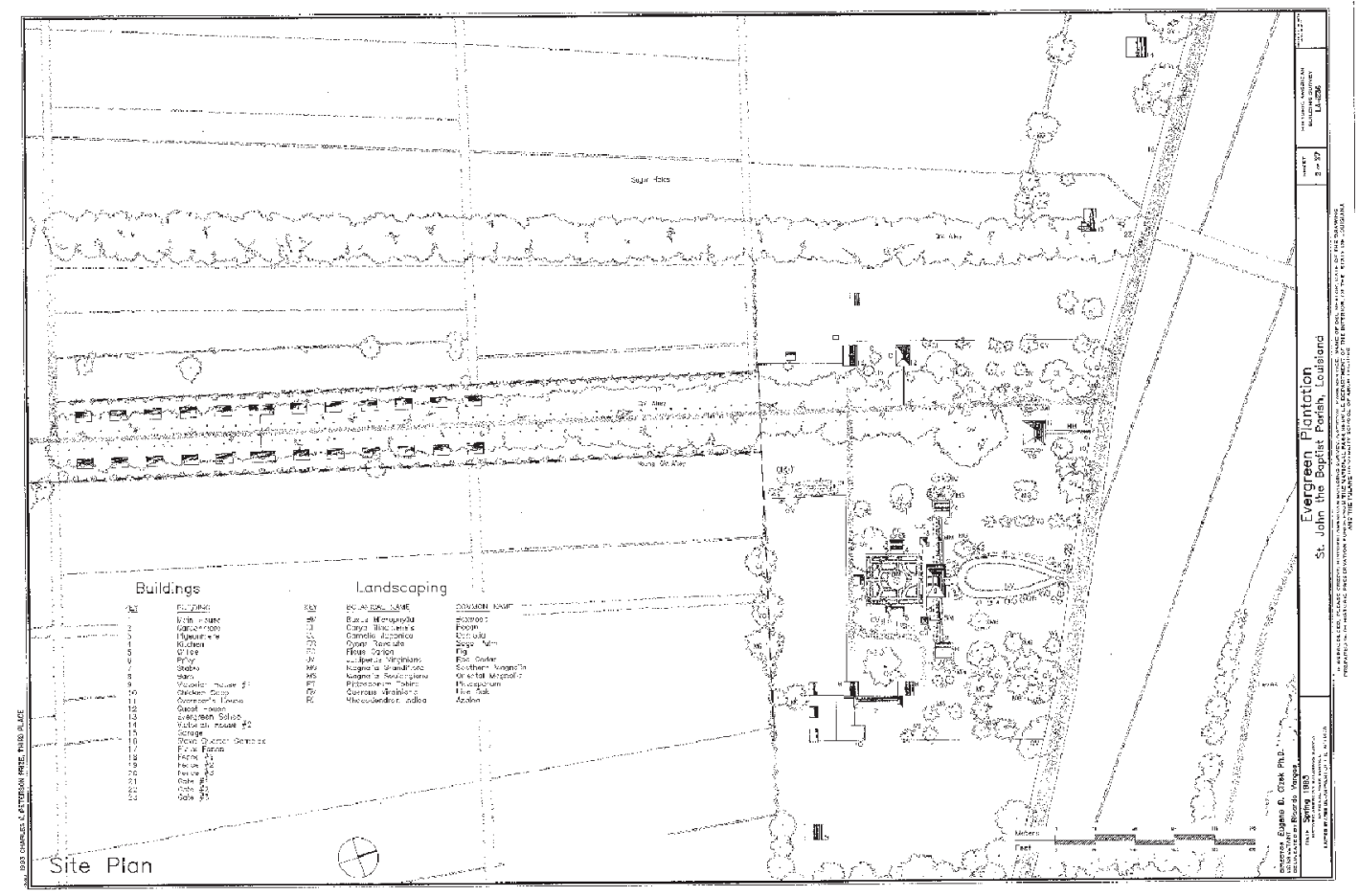

Figura 14 - Esquema de implantação da plantation Evergreen, Lovisiana. Coleção Historic American Buildings Survey da Biblioteca do Congresso, Washington, D.C. (cortesia da Prints and Photographs Division da Biblioteca do Congresso, EUA).

ao que se observava no Delta do Mississippi (Figura 19): casa de vivenda voltada para a entrada da plantation (no caso, na beira da estrada, e não do rio), moradias escravas em linha, na retaguarda e afastadas da casa senhorial, instalações produtivas ao final da alameda das senzalas. Vlach (1993, p. 189190) esclarece que nem todos os cativos de Thornhill residiam nas moradias que aparecem no plano; cerca de dois terços da escravaria vivia em dois agrupamentos de senzalas próximos aos campos de algodão.

último exemplo a ser apontado para o caso norte-americano é, certamente, o mais célebre, e servirá para demonstrar a existência de um padrão comum em todo o sul dos Estados Unidos, de Chesapeake ao Golfo do México. Refiro-me a Monticello, a famosa plantation de Thomas Jefferson, visitada exaustivamente desde o século XIX e transformada em um dos principais lugares da memória da República norte-americana. Seu projeto, elaborado pelo próprio Jefferson, baseou-se em uma leitura direta dos Quattro Libri de Palladio, combinando essa referência com outras matrizes arquitetônicas. De todo modo, a primeira referência foi primordial, sobretudo na consecução do plano em U (Figuras 20 e 21 ). Palladio considerava essas dependências laterais como os "braços" da villa, cuja cabeça e tronco seriam exatamente a casa-grande; por essa razão, aos braços eram reservadas as instalações voltadas para a produção e o serviço da casa de vivenda. Em seu projeto de 1772, Jefferson inspirou-se 


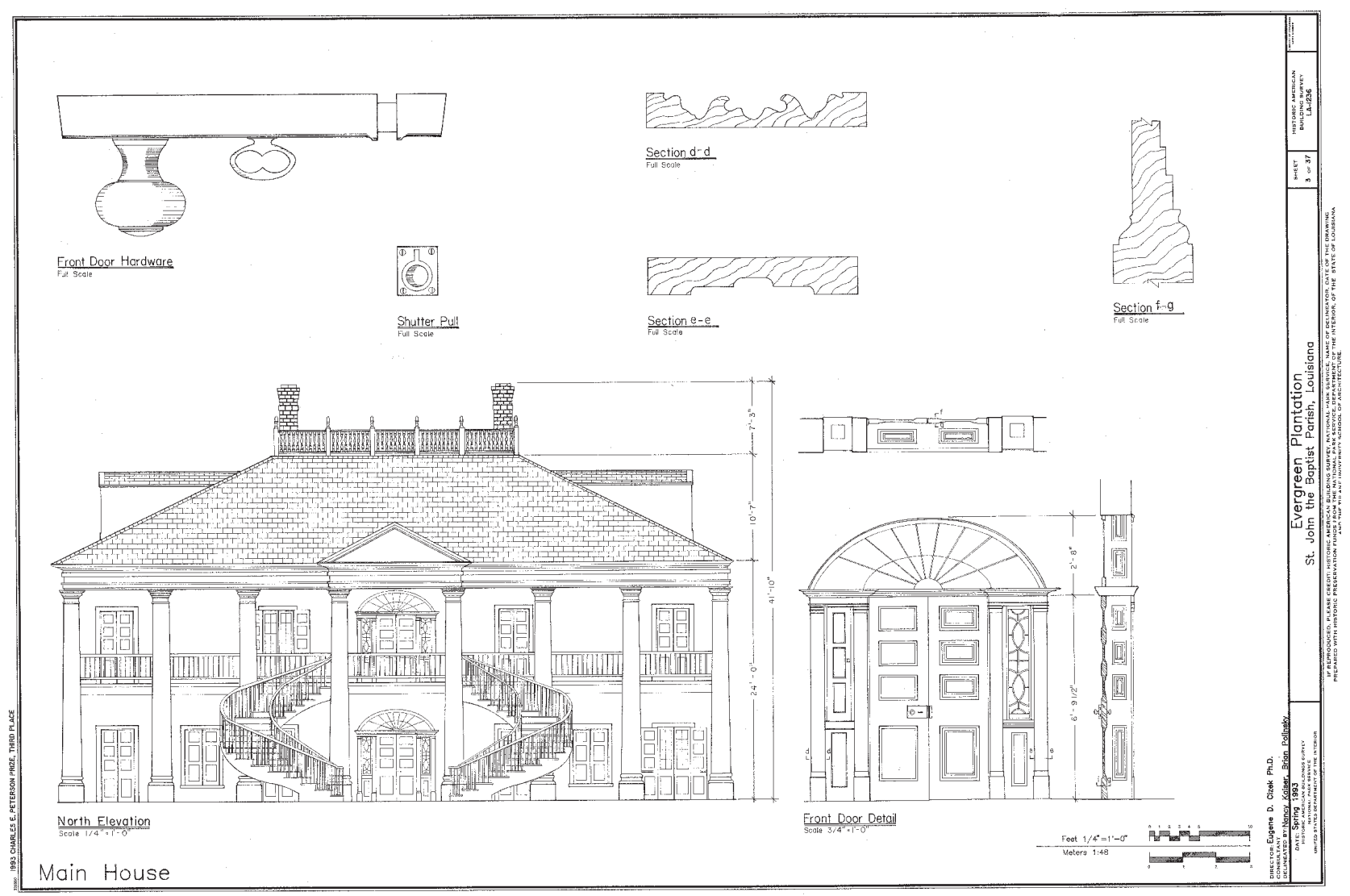

Figura 15 - Vista frontal casa de vivenda da plantation Evergreen, Louisiana. Coleção Historic American Buildings Survey da Biblioteca do Congresso, Washington, D.C. (cortesia da Prints and Photographs Division da Biblioteca do Congresso, EUA).

claramente em Palladio, imprimindo-lhe, no entanto, a brutalidade das relações escravistas de poder. Organizados em dois pavimentos, os braços do Monticello tinham, em sua parte superior, um terraço para desfrute da família e visitantes brancos, e, em sua parte inferior, as dependências de serviço e os alojamentos dos escravos domésticos.

Os brancos literalmente andavam sobre as cabeças dos negros. Subjacente a tal escolha arquitetônica, havia a idéia de apagar do raio de visão senhorial a presença da população escravizada, e é nisso que Monticello se aproximou das demais plantations do sul dos Estados Unidos. Tal como nas outras unidades escravistas examinadas, os trabalhadores rurais que Jefferson mantinha no cativeiro residiam em agrupamentos alinhados de senzalas, afastados da sede (ACKERMAN, 1990, p. 186, 193; DALZELL JR., 1993).

Como explicar esse modelo de implantação? Como se viu, a resposta não se encontra no programa de necessidades da produção do açúcar, do algodão ou de outros gêneros, mas sim no quadro das relações sociais e políticas mais amplas. Dentre as sociedades escravistas do Novo Mundo, o sul dos Estados 


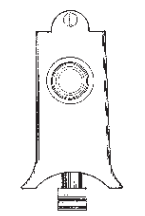

Window Shutter Lock

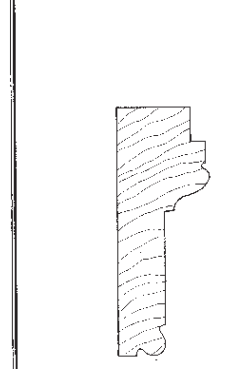

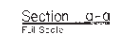

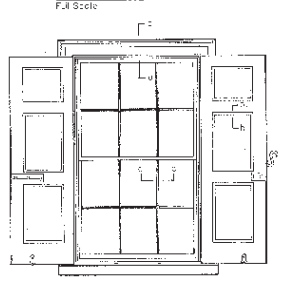

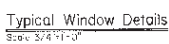

Main House

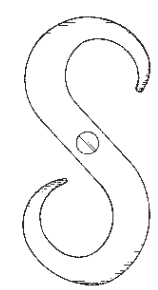

$\frac{\text { Shtuter Caich }}{\text { wis iscli }}$

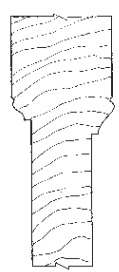

Section b-b
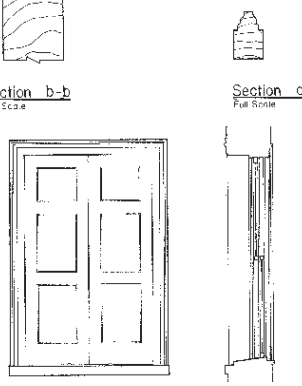

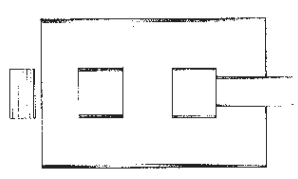

$\frac{\text { Shutter Latch }}{\text { Full sonie }}$
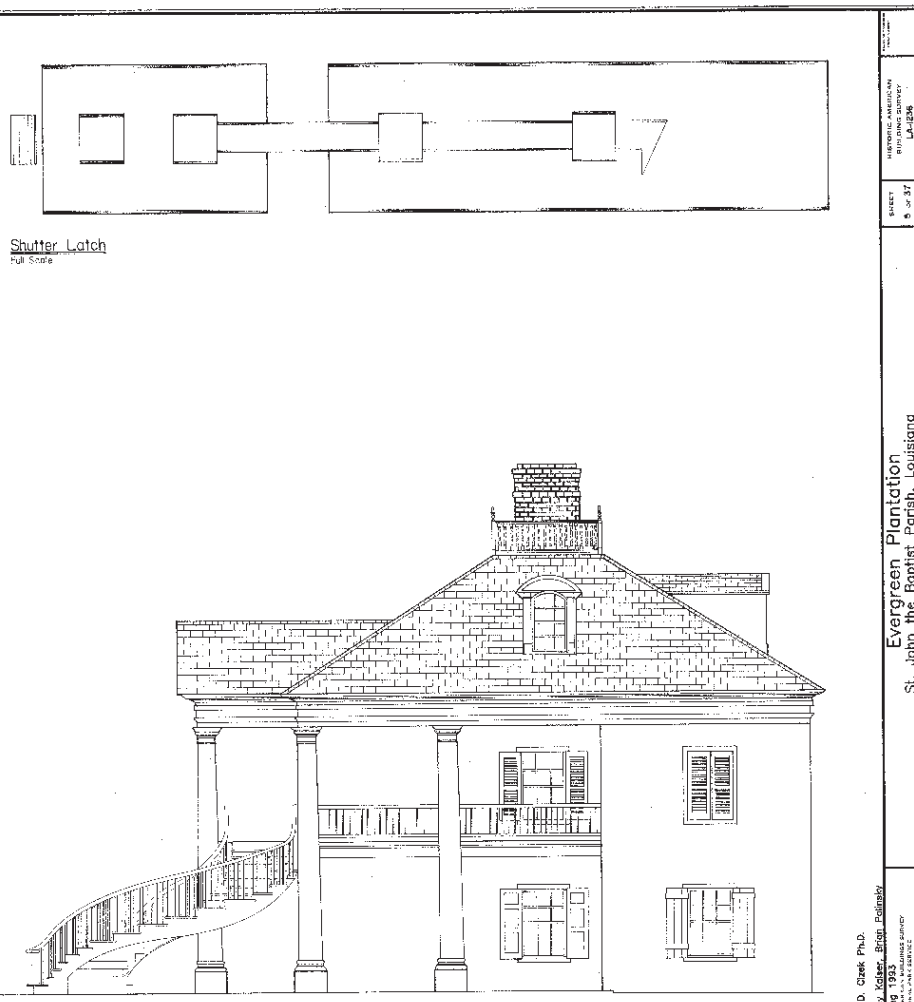

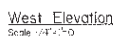

Figura 16 - Vista lateral casa de vivenda da plantation Evergreen, Louisiana. Coleção Historic American Buildings Survey da Biblioteca do Congresso, Washington, D.C. (cortesia da Prints and Photographs Division da Biblioteca do Congresso, EUA).

Unidos se notabilizou pela cisão absoluta entre o universo dos brancos livres e o universo dos negros escravizados, algo que foi sendo paulatinamente construído ao longo do século XVIII, consolidando-se de forma definitiva na primeira década dos oitocentos, quando a pele negra se tornou marca de um estatuto permanentemente subalterno. Isso foi decorrência, em primeiro lugar, da virtual ausência de alforrias no sul la exceção foi o breve período que se seguiu à Guerra de Independência), que levava a uma associação quase imediata entre a cor negra e a condição escrava, e, em segundo lugar, do próprio mecanismo de reprodução de seu sistema escravista. Como se sabe, o crescimento vegetativo da população escrava - presente em Chesapeake desde o início do século XVIII e, em Lowcountry, desde sua segunda metade - possibilitou, na centúria seguinte, a incrível expansão do escravismo norte-americano sem a necessidade do tráfico negreiro transatlântico (GENOVESE, 1974; BERLIN, 1998; MORGAN, 1998).

$\bigcirc$ fato de a escravaria ser crioulizada, de se organizar em núcleos familiares relativamente estáveis e de a população negra livre ser diminuta e 

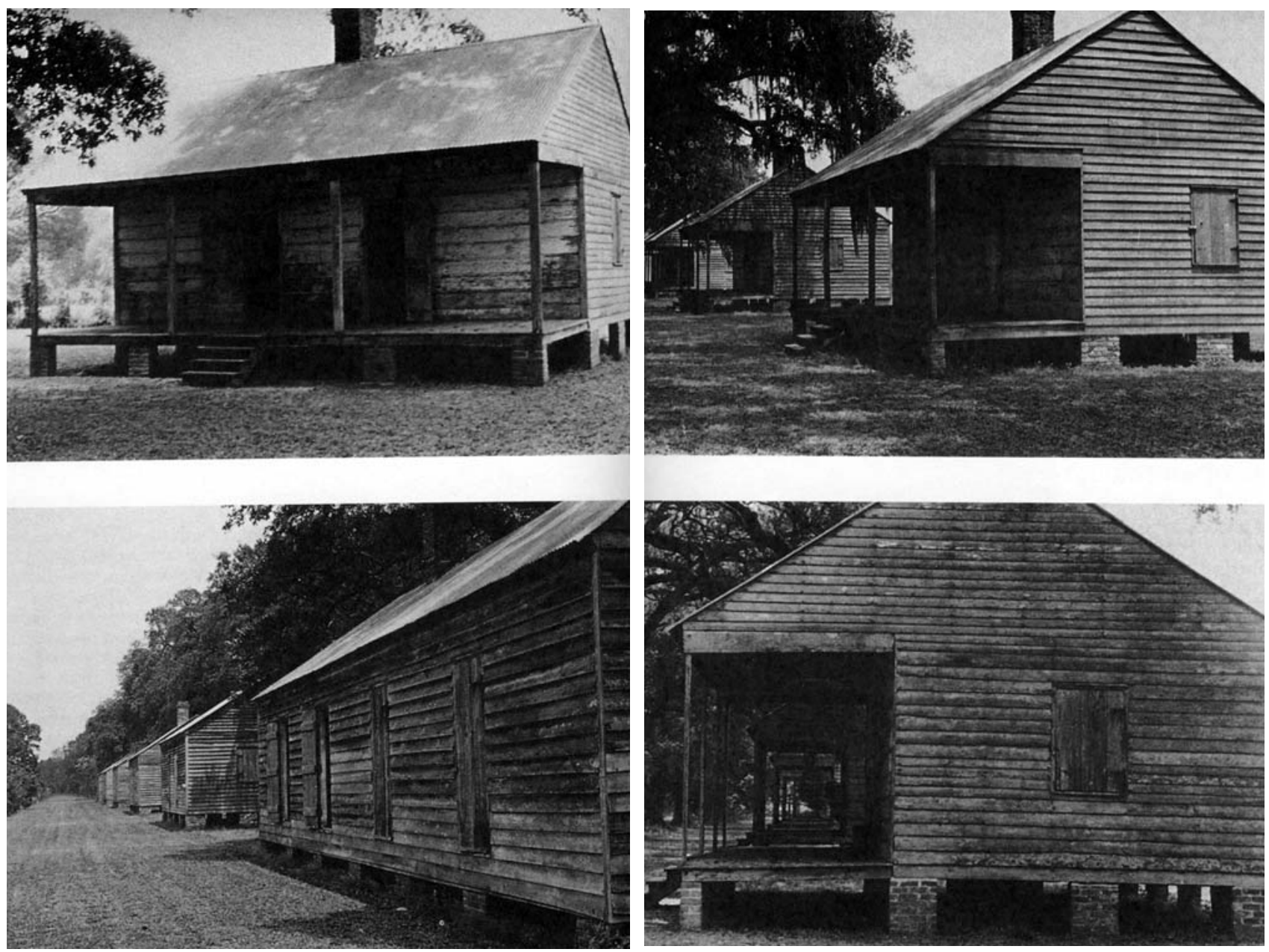

Figura 17 - Senzalas da plantation Evergreen (CARANDINI, 1984, v. 1, p. 200).

estritamente vigiada pelos poderes públicos dispensou a adoção, dentro das plantations, de formas rigorosas de confinamento espacial. Em uma frase, o risco de fugas ou rebeliões não teve qualquer papel na conformação da moradia escrava no sul dos Estados Unidos. Daí as senzalas não terem trancas e não serem vigiadas de perto pelo olhar branco, o que em absoluto significou ausência de controle ou interferência senhorial. Simetria e uniformidade arquitetônicas eram, em si, um terrível ato de expressão do poder dos senhores sobre seus escravos, algo que os últimos percebiam de forma cristalina (VLACH, 1993, p. 162-1651.

Mais importante, no entanto, foi o fato de as casas de vivenda buscarem poucos efeitos de representação diante dos escravos. De acordo com a sugestão de Epperson (1999, p. 168), a escravaria não era a audiência primordial da arquitetura veiculada pelas casas-grandes do sul dos Estados Unidos. Elas, afinal, davam suas costas para as senzalas, voltando-se antes aos 


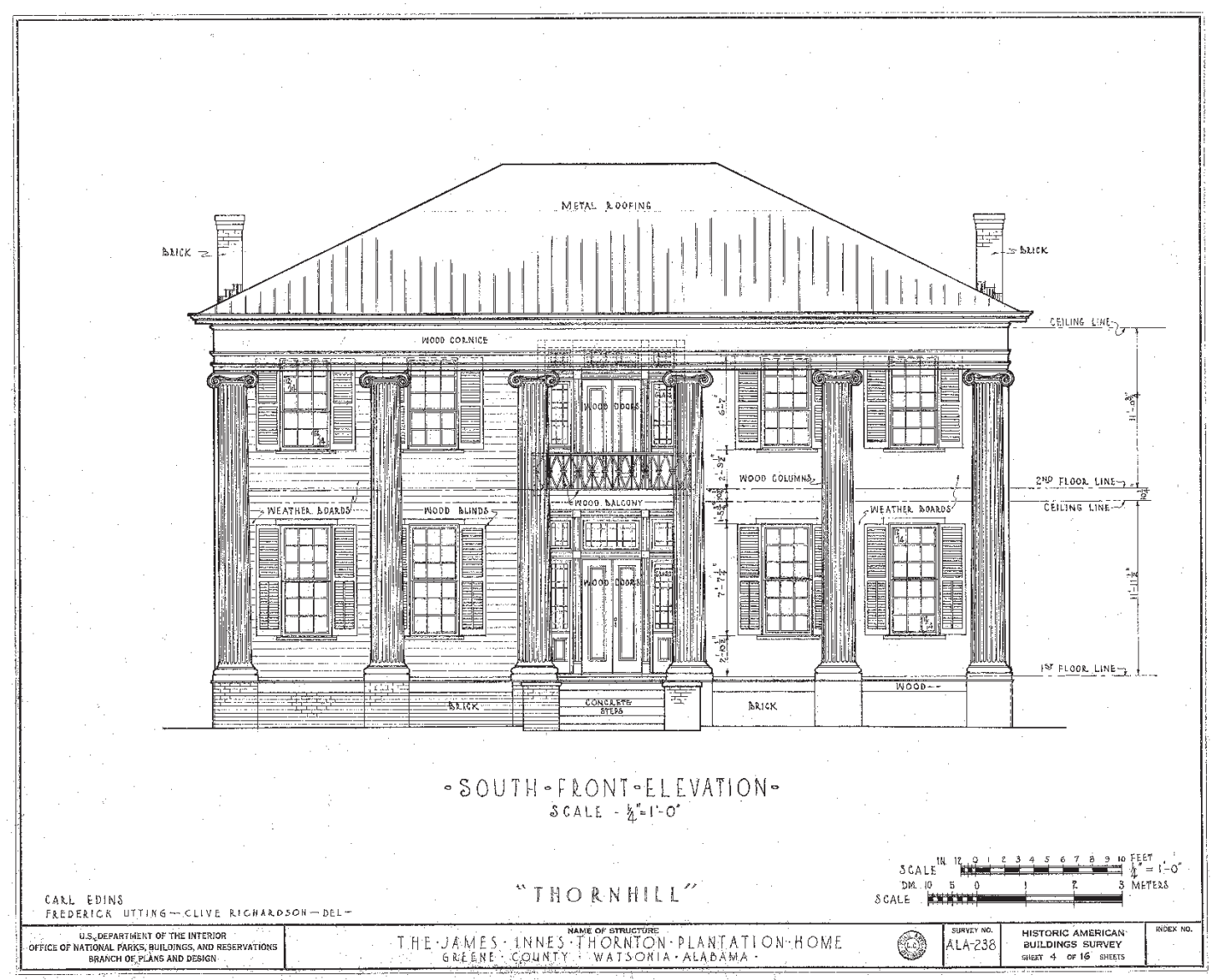

Figura 18 - Carl Edins, Frederick Utting e Clive Richardson. Elevação frontal da plantation Thornhill,. 19341935. Coleção Historic American Buildings Survey da Biblioteca do Congresso, Washington, D.C. (cortesia da Prints and Photographs Division da Biblioteca do Congresso, EUA).

rios e às estradas, isto é, às vias por onde trafegavam aqueles que iriam consumilas visualmente. Noutras palavras, seu público-alvo era a comunidade branca, e, para entender corretamente o ponto, deve-se mirar para o sistema político norte-americano anterior à Guerra Civil.

É hoje assente, na historiografia, que os estados do sul eram regidos por uma verdadeira democracia eleitoral, baseada, no entanto, numa clivagem racial profunda entre brancos - inclusive os pobres - com plenos direitos políticos, e negros, sem direito algum. A rigor, era justamente a presença da escravidão negra que fornecia a base material e ideológica para a igualdade política entre os brancos. A fim exercerem o controle do jogo político, os grandes proprietários tinham que lutar pelos votos e pelo apoio dos pequenos proprietários escravistas ou mesmo dos não-proprietários de escravos (COOPER JR., 2000; PARISH, 1989, p. 124-138). Nesse jogo, o papel das casas-grandes monumentais foi de grande relevância: ao exprimirem o poder, o sucesso empresarial e a capacidade de liderança de seus senhores, acabaram por prestar serviços 


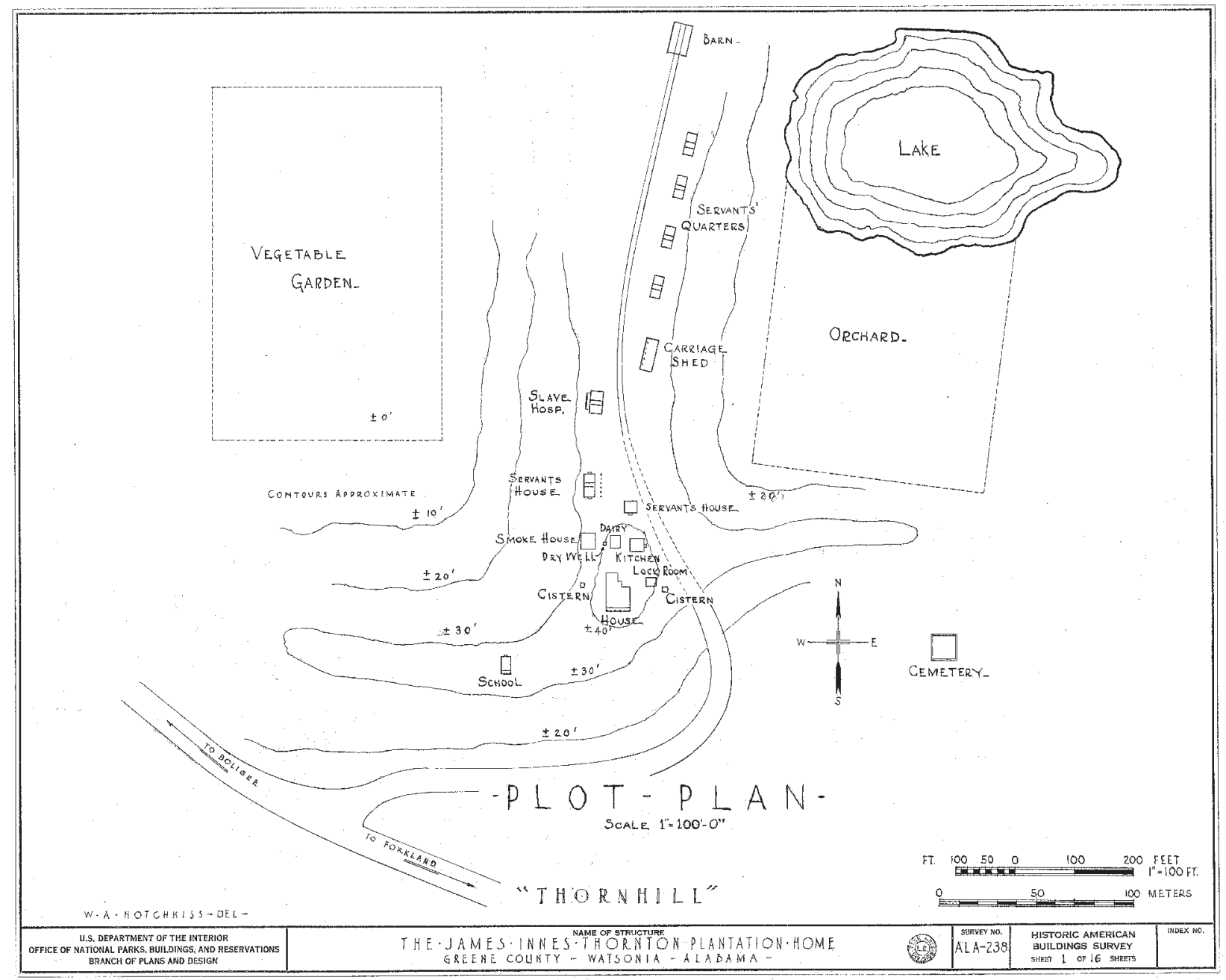

Figura 19 - W. A. Hotchkiss, Implantação de Thornhill, 1934-1935. Coleção Historic American Buildings Survey da Biblioteca do Congresso, Washington, D.C. (cortesia da Prints and Photographs Division da Biblioteca do Congresso, EUA).

importantes ao exercício da hegemonia dos grandes plantadores sobre a sociedade sulista.

círculo se fecha uma vez mais com Monticello. O republicanismo jeffersoniano ofereceu aos senhores de escravos sulistas o núcleo duro de sua ideologia política. Esse ideário bebia diretamente no modelo de ordem e independência veiculado pela tradição dos teóricos ingleses da commomwealth e também do palladianismo, e que, por sua vez, era plenamente compativel com o paternalismo que estava na base do ethos senhorial (MORGAN, 1975; OAKES, 1990; ASHWORTH, 1995). Por todas essas razões, segundo o raciocínio dos proprietários, seus escravos, racialmente inferiores e equivalentes a adolescentes brancos, jamais poderiam ocupar a face mais visível das plantations. 

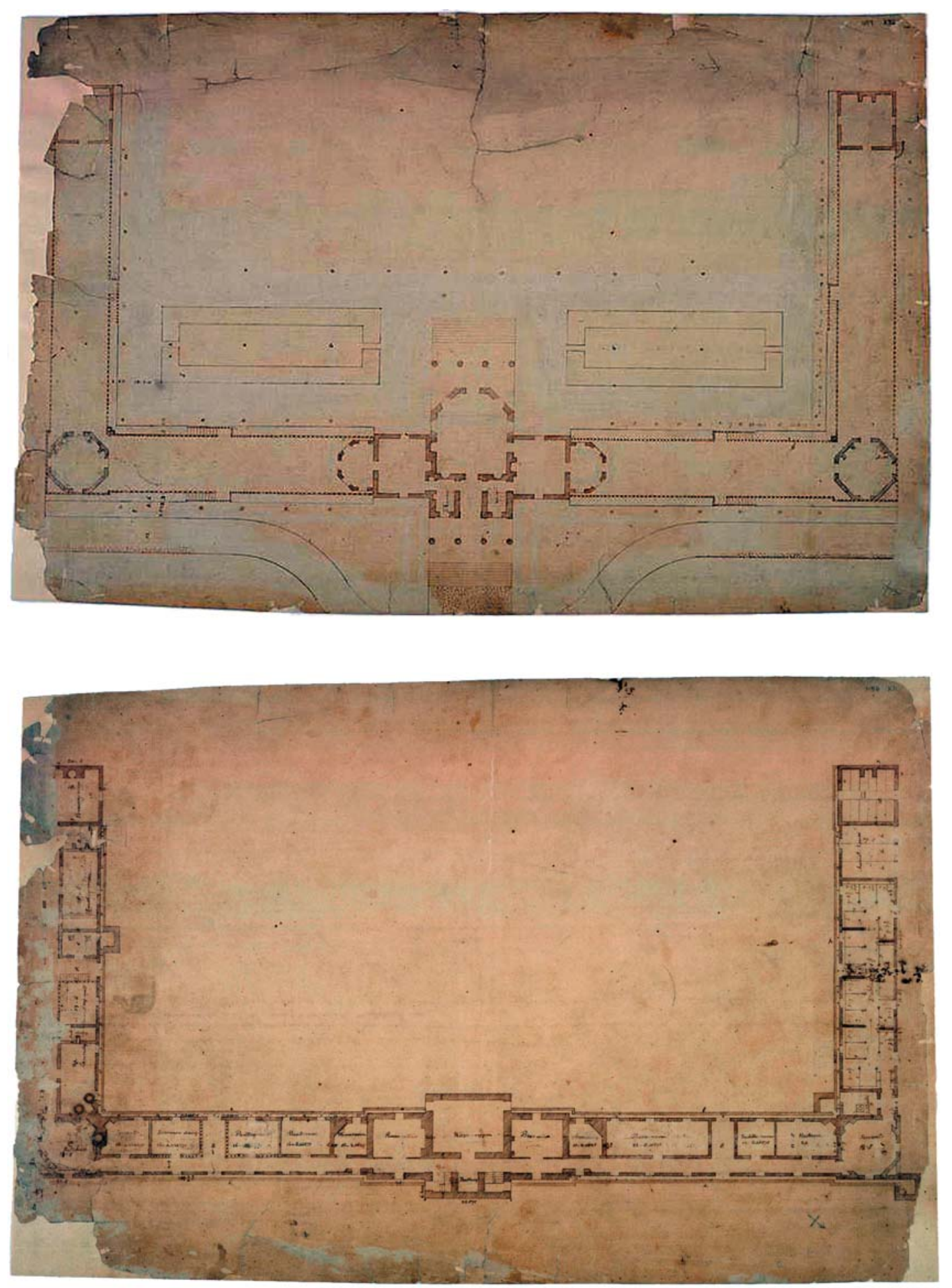

Figura 20 - Projeto de Thomas Jefferson para Monticello, c. 1772. Coolidge Collection, k31, k32 (cortesia da Massachusetts Historical Society, Boston, EUA). 


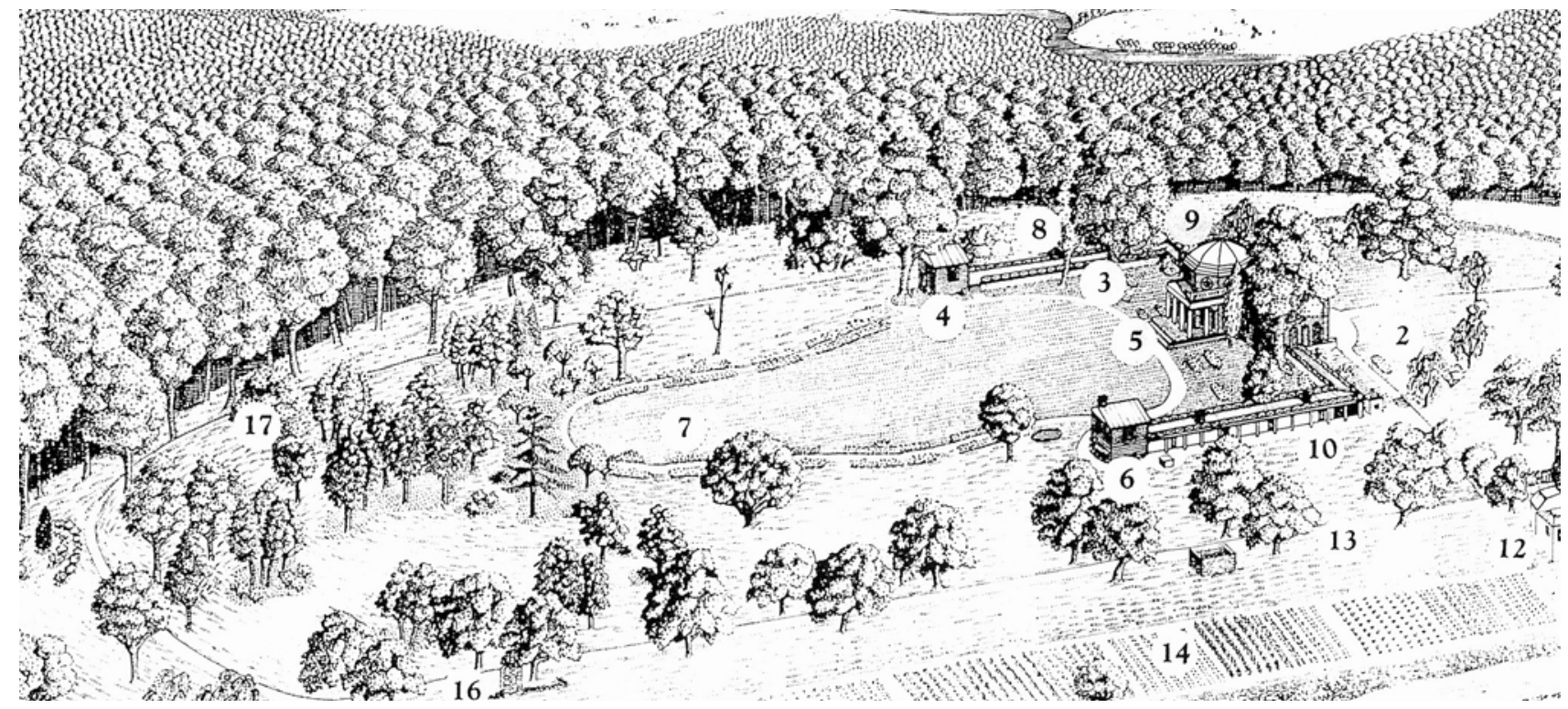

Figura 21 - Vista a vôo de pássaro, plantation Monticello (CARANDINI, 1984, v. 1, p. 190).

Cuba e o estatuto colonial

Os grandes engenhos açucareiros cubanos erigidos após a década de 1830 seguiram um padrão radicalmente distinto de implantação arquitetônica. Bem o demonstram os exemplares apresentados no álbum ilustrado Los Ingenios, editado em Havana em 1857. Já tivemos oportunidade de observar algumas de suas litografias na primeira parte deste artigo (Figuras 3, 4 e 5). 0 livro, publicado sob a patronagem, e com textos explicativos, do proprietário escravista Justo Cantero, nascido em Trinidad e formado em medicina pela Universidade de Harvard, pretendia servir simultaneamente como uma peça de propaganda do setor mais empreendedor da classe senhorial - afinada com o espírito científico e tecnológico do mundo industrial - e como um meio de difundir entre todos os produtores cubanos o avanço técnico que vinha ocorrendo nos grandes engenhos de açúcar da ilha. Seu destaque, contudo, não era o texto de Cantero. A obra continha vinte e oito litogravuras coloridas, de grande beleza, compostas com um notável apuro técnico pelo artista francês Eduardo Laplante, até então empregado na indústria tabaqueira cubana. Dessas litogravuras de Laplante, vinte e seis representavam os grandes engenhos mecanizados e semimecanizados de Cuba, acrescidas por mais seis plantas arquitetônicas de alguns deles (VENEGAS, 1996; TOMICH, 2005b).

Passemos ao exame da implantação de três engenhos desta série. $\bigcirc$ primeiro deles - o Flor de Cuba, pertencente à família Arrieta - foi o que recebeu maior destaque no livro, pois, afora uma vista do conjunto, Laplante inseriu em sua obra a planta arquitetônica e uma representação interna da casa das caldeiras 
(Figura 4). Fundado em 1838, esse engenho localizava-se a doze léguas da baía de Cárdenas. Com uma capacidade produtiva superior a 3 mil toneladas métricas anuais, garantida pela completa mecanização do processo de fabricação, em 1857, o Flor de Cuba empregava uma força de trabalho composta por 409 escravos e 170 collies chineses (CANTERO; LAPLANTE, 1857). Na vista composta por Laplante, dois edifícios chamam a atenção do observador (Figura 22). A despeito de o primeiro plano ser ocupado por um açude e pelas oficinas de carpintaria, o olhar é logo atraído para o edifício localizado ao fim da estrada de acesso, tanto mais destacado pela presença de três altas chaminés. Trata-se da casa das caldeiras movidas a vapor, que abrigava não apenas o maquinário a vácuo mas igualmente o jogo das centrífugas e as moendas horizontais interligadas por esteiras móveis. O outro edifício em questão é o enorme barracão que alojava os trabalhadores do engenho, localizado ao fundo na imagem. Medindo 144 por 128 metros, foi um dos maiores construídos em Cuba (FRAGINALS, 1987). A casa de vivenda senhorial de dois pavimentos, em posição perpendicular entre a casa das caldeiras e a casa de purgar, praticamente desaparece diante dessas grandes construções.

Ainda que suas dimensões fossem menores, o ingenio Unión, pertencente a Lamberto Fernández e localizado na jurisdição de Cienfuegos, tinha uma planta semelhante ao Flor de Cuba. Como se pode ver em sua litografia (Figura 23), o centro do conjunto é ocupado pelo eixo composto por casa das caldeiras - totalmente mecanizada, algo que se depreende visualmente pela presença de uma única chaminé - e casa de purgar. Entre esses dois edifícios,

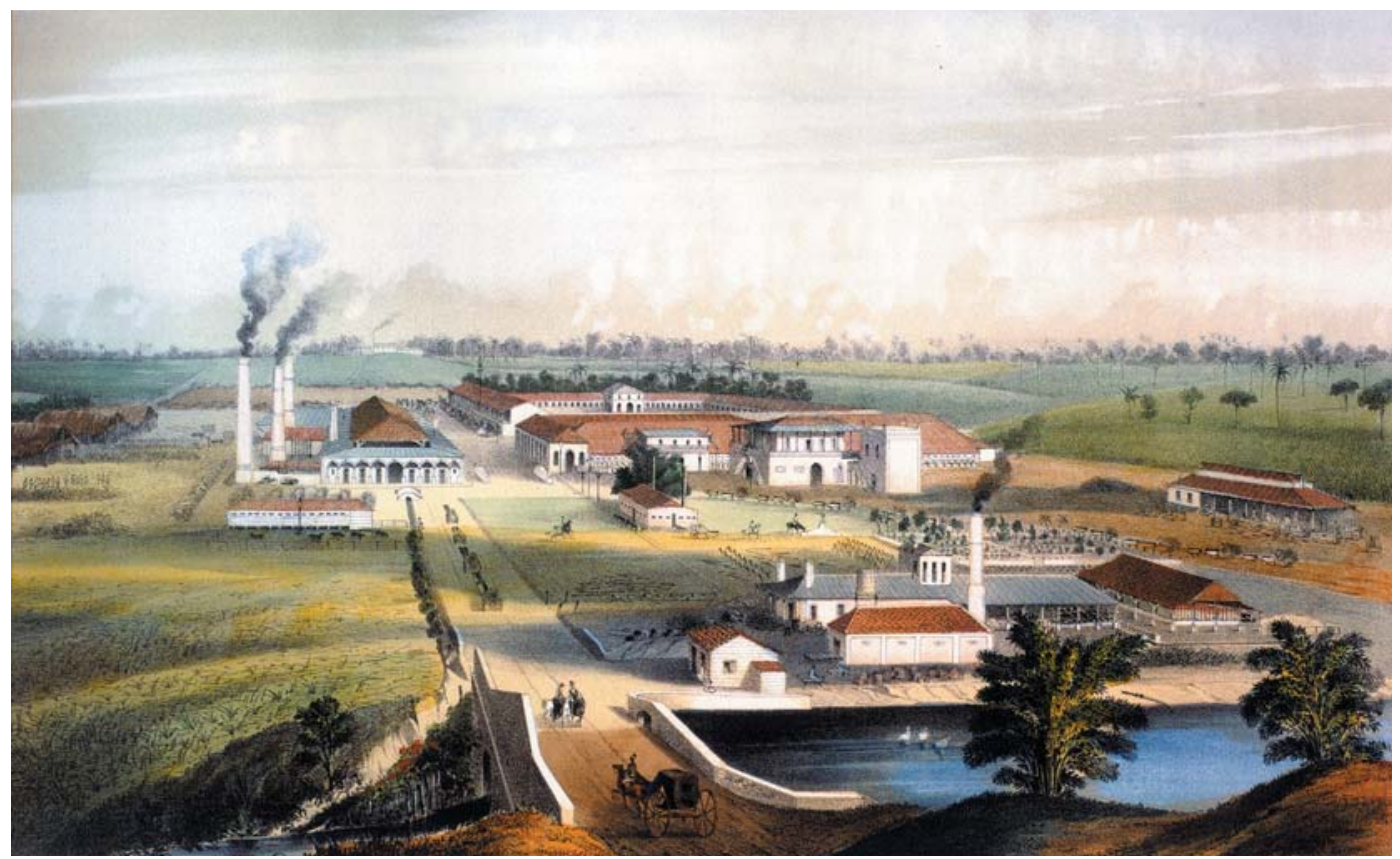

Figura 22 - Eduardo Laplante, Vista do engenho Flor de Cuba, litografia (CANTERO; LAPLANTE, 1857). 


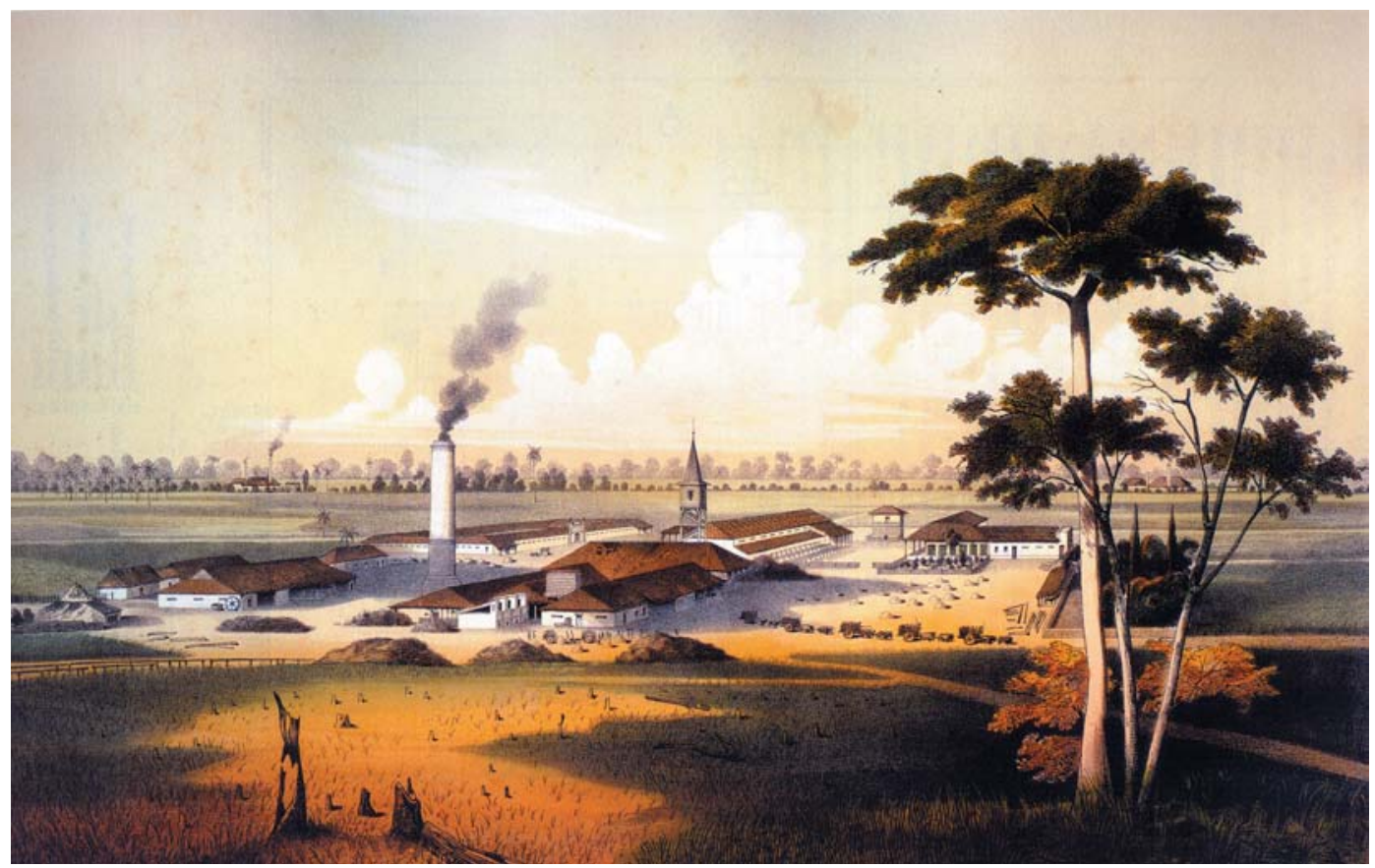

Figura 23 - Eduardo Laplante, Vista do engenho Unión, litografia (CANTERO; LAPLANTE, 1857).

projeta-se o campanário do engenho, ponto de observação dos trabalhos no batey e locus da marcação do tempo do engenho pelo relógio. Em lados opostos, ficam a casa de vivenda, com plano em L, e o barracão dos escravos, em plano retangular. Novamente, para se encontrar a casa senhorial, exige-se do observador uma certa atenção.

terceiro exemplo é o do ingenio Armonía, localizado na jurisdição de Güines e pertencente à sociedade de Miguel de Aldama e José Luís Alfonso. Neste caso, Laplante optou por conjugar uma vista interna da casa das caldeiras (Figura 24) com a planta do conjunto arquitetônico (Figura 25). Como bem ressalta o historiador Carlos Venegas,

[...] o ingenio Armonía [...] era um modelo de distribuição espacial - daí seu nome - por sua orientação geográfica, posição dos edifícios, delineamento dos campos, tudo harmonicamente organizado a partir de uma grande casa de máquinas com planta em forma de cruz, que ocupava o centro da plantação, com acessos de todos os ângulos facilitando o ritmo da produção desde os mesmos campos, como uma totalidade agroindustrial (Venegas, 1996, p.97).

A esse registro, deve-se acrescentar algo a respeito das posições relativas da casa de vivenda e da senzala. Assim como em muitos dos grandes engenhos cubanos mecanizados e semimecanizados, a moradia escrava do Armonía consistia em um enorme barracão, de pátio construído em alvenaria, cujas características marcantes eram a entrada única, fechada com portão de 
ferro, as trancas noturnas, os cubículos sem janelas, com pequenas frestas gradeadas e portas voltadas ao pátio (MARQUESE, 2005). Do lado oposto ao barracão, encontrava-se a casa de purgar. Abaixo, localizava-se a casa de vivenda senhorial, ladeada, à direita, por uma horta e pela serralheria e, à esquerda, por um jardim e pela enfermaria dos escravos. Moradia senhorial e moradia escrava, portanto, eram claramente separadas e ocupavam, no conjunto, uma posição secundária frente à centralidade dos edifícios voltados à produção açucareira.

Uma mirada na totalidade das litogravuras de Laplante levanta um problema: com exceção dos engenhos Manacas e Buena Vista, ambos localizados no Valle de los Ingenios, em Trinidad, e o segundo deles pertencente a Cantero, todos os demais não tinham casas de vivenda que se destacassem no conjunto das edificações. Com efeito, mesmo nas maiores unidades açucareiras ou em engenhos como o Manacas e o Buena Vista, as casas senhoriais, ainda que seguissem padrões de arquitetura erudita claramente filiados ao movimento neoclássico, eram relativamente simples, caso as comparássemos com suas equivalentes do sul dos Estados Unidos e, como se verá adiante, do Vale do Paraíba cafeeiro. Além do mais, em muitos desses engenhos a moradia escrava se caracterizava por uma forma arquitetônica única no conjunto das plantations americanas, o barracão de pátio.

Novamente, para compreender a especificidade da implantação arquitetônica dos engenhos cubanos, devemos voltar nosso foco ao esquadro

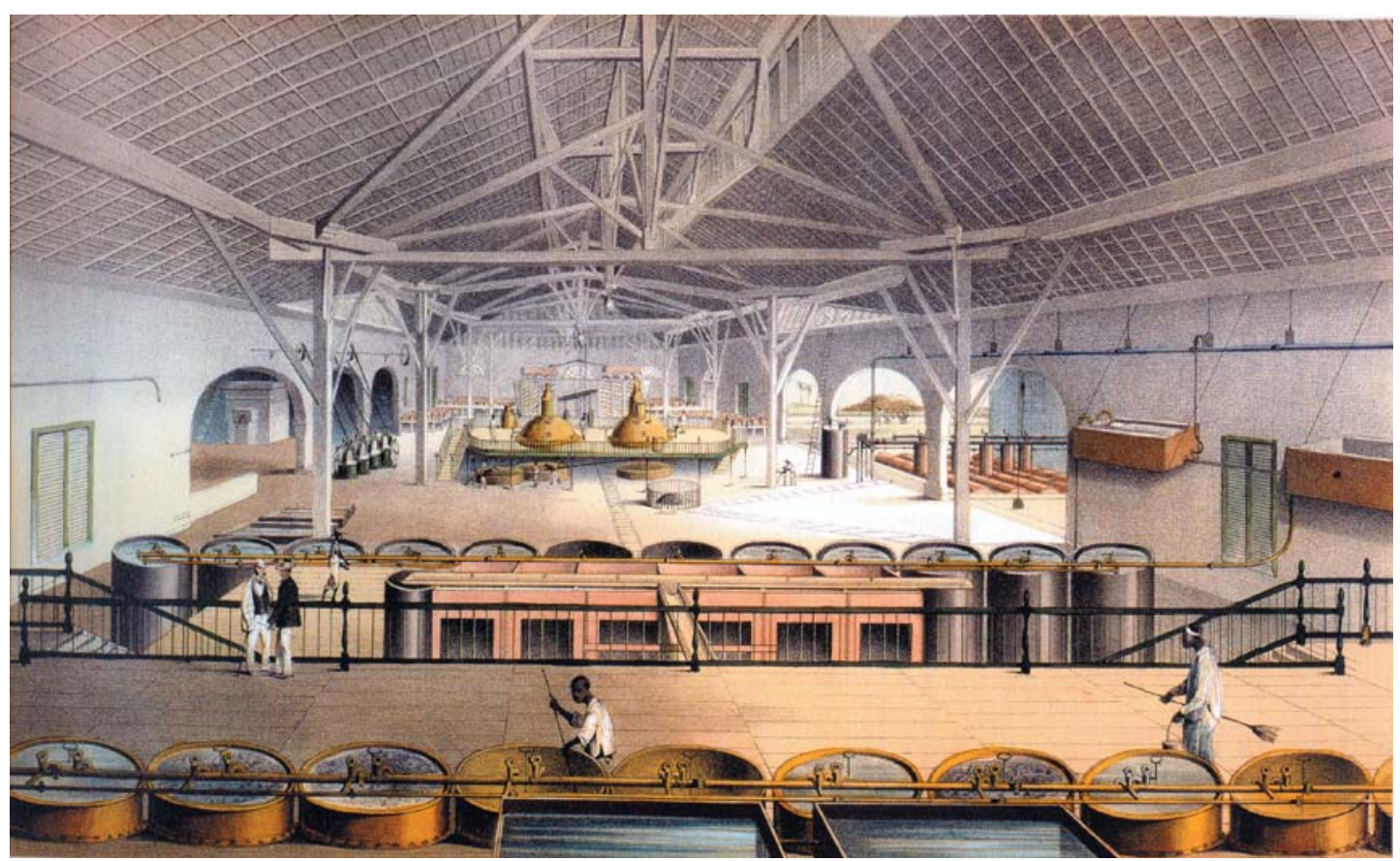

Figura 24 - Eduardo Laplante, Casa das caldeiras do engenho Armonía, litografia (CANTERO; LAPLANTE, 1857). 


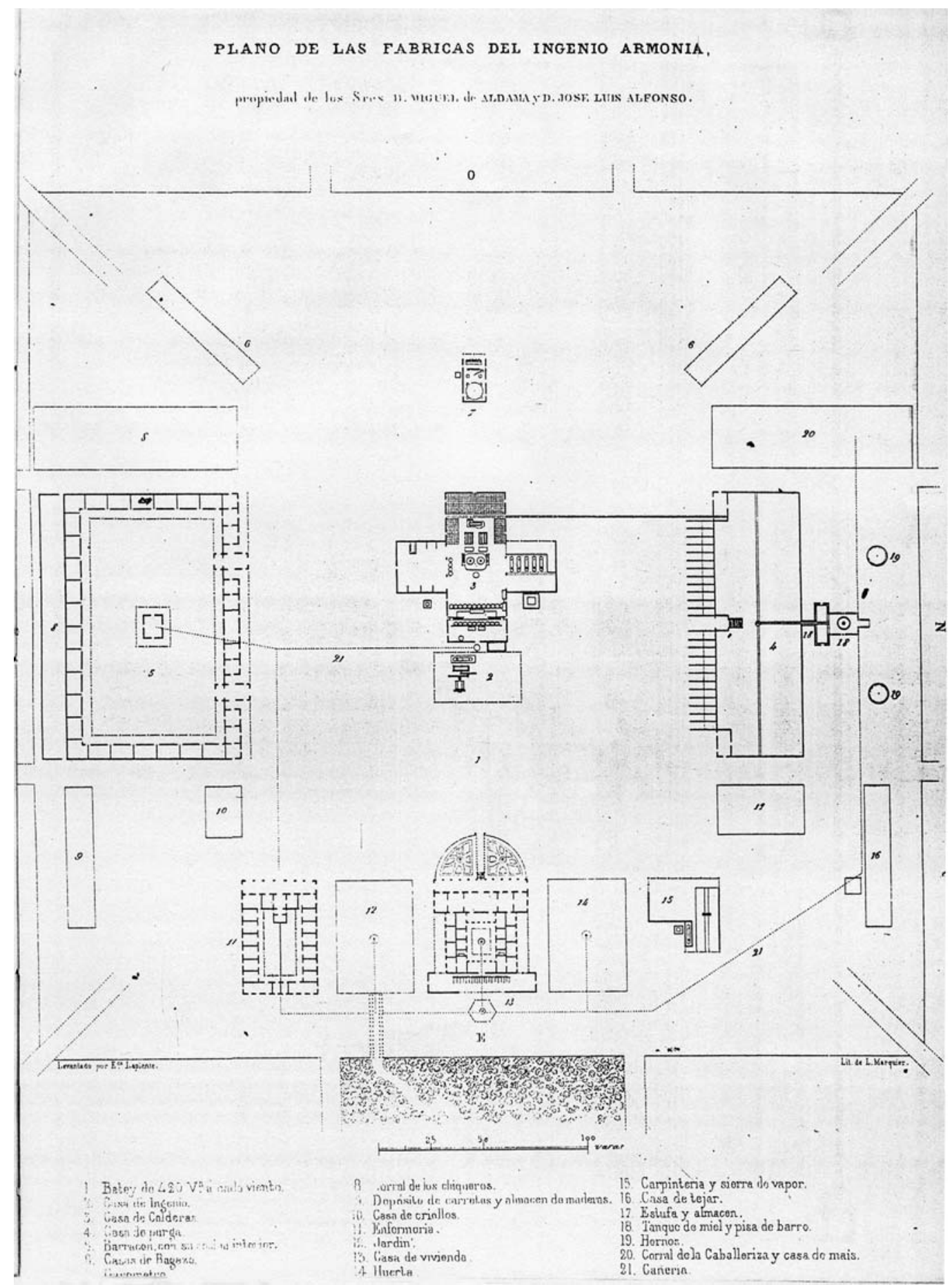

Figura 25 - Eduardo Laplante, Implantação do engenho Armonía, litografia (CANTERO; LAPLANTE, 1857). 
das relações sociais e políticas. $\bigcirc$ dado fundamental, aqui, é a ordem colonial da ilha. No contexto da crise do regime colonial espanhol, Cuba e Porto Rico foram as únicas colônias que permaneceram atadas à metrópole. Como há muito é salientado pela historiografia sobre o caso cubano, esse caminho derivou do projeto escravista de suas classes senhoriais. Em troca do apoio espanhol para a manutenção da escravidão e do tráfico negreiro transatlântico diante das crescentes pressões inglesas, sua elite seguiu à risca o tema da "sempre fiel ilha de Cuba". Tal opção valeu tanto para os períodos em que seus representantes tiveram assento nas Cortes peninsulares, gozando Cuba da condição de província do reino espanhol (como ocorreu entre 1810-1814 e 1820-1823), como para os períodos de regresso absolutista (1814-1820, 1823-1836). Mesmo por ocasião das Cortes liberais de 1836-1837 - quando Cuba deixou de ser considerada província da Espanha e seus deputados foram impedidos de tomar assento em Madri -, a elite escravista não questionou a relação com a metrópole. Se a decisão representou uma derrota para os liberais reformistas cubanos, a elite açucareira escravista aceitou de bom grado o novo estatuto da ilha ${ }^{4}$.

Qual o significado disso tudo para a arquitetura dos engenhos? Ora, - locus para o exercício da política não se encontrava no nível local, na região dos engenhos, mas sim em Havana, onde residiam o Capitão-Geral e o Intendente, responsáveis respectivamente pelo governo militar-civil e pelo governo econômico da ilha. Os grandes senhores, proprietários de vários engenhos, só estacionavam em suas unidades açucareiras no período de safra, efetuada no inverno ou na estação seca, quando diminuíam as chuvas e o clima se tornava mais agradável. Noutras palavras, as casas de vivenda dos engenhos cubanos não desempenhavam qualquer papel no jogo político insular, representando apenas um pouso ou, no máximo, um lugar de deleite familiar (VENEGAS, 1996).

Espaço de pouso e deleite, dominado, no entanto, por uma população predominantemente africana e refratária ao mando senhorial. A despeito de sua proibição em 1820, o tráfico transatlântico de escravos para Cuba prosseguiu na ilegalidade até bem entrada a década de 1860. A concentração de enormes massas de africanos escravizados nas plantations da ilha acirrou suas tensões sociais. Os constantes levantes e os crescentes rumores de planos de articulação entre abolicionistas ingleses e escravos dos engenhos levaram os grandes senhores cubanos a adotar formas rigorosas de confinamento dos trabalhadores cativos. Para tanto, recorreram à experiência que tinham como traficantes de escravos na Costa d'África - caso de Aldama, Alfonso e muitos outros. Como procurei demonstrar em outro texto, os barracões de pátio que foram construídos em Cuba após a década de 1830 se inspiraram diretamente nos barracões de embarque dos cativos antes da travessia transatlântica (MARQUESE, 2005).

Elaborar a imagem de que submetiam seus escravos por laços paternais nunca passou pela cabeça dos grandes senhores cubanos. Aos cativos, cabia o cárcere do barracão, longe da vista da casa de vivenda, reservada para a safra. $\bigcirc$ engenho era compreendido antes como uma fábrica no campo do que como o lugar de moradia de uma família extensa, representação senhorial corrente no sul dos Estados Unidos e no Brasil. As plantations açucareiras exigiam
4. Sigo, nesse ponto, as interpretações de TORRES CUEVAS (1994, p. 335353) e FRAGINALS (1995, p. 190-205). Para uma interpretação alternativa, verFRADERA (1999,p.7193). Ver igualmente os trabalhos de SCHMIDT-NOWARA (1999) E BERBEL; MARQUESE (2005) 
5. O inventário, de 1835 , da meia-irmã de Luciano José de Almeida, Domiciana Maria da Conceição, herdeira e proprietária da fazenda Boa Vista, registra a construção parcial de seu sobrado, mas não anota nada a respeito das senzalas em quadra. A propriedade foi adquirida por Luciano junto a José Ramos Nogueira, seu cunhado e viúvo de Domiciana, em fins dessa década.Os inventários de 1835 (Domiciana Maria da Conceição) e 1854 (Luciano José de Almeida), referentes ao Cartório do $1 .^{\circ}$ Ofício de Bananal, estão depositados no Museu Histórico e Pedagógico Major Novaes, Cruzeiro, SP Sobre a genealogia da família, ver ainda RODRIGUES (1980) e FARIA (1995). pesados investimentos, e, no caso das unidades mecanizadas, uma complexa tecnologia que as colocava no mesmo passo do desenvolvimento industrial dos países centrais. Para uma classe senhorial ciosa de sua imagem empreendedora, era mais do que lógico que o centro do conjunto arquitetônico fosse ocupado pela casa das caldeiras.

Império do Brasil e o jogo do clientelismo

As plantations do Vale do Paraíba cafeeiro guardaram pontos de contato e de afastamento em relação às suas congêneres do sul dos Estados Unidos e de Cuba. O primeiro exemplo a ser exposto é o da fazenda Boa Vista (Bananal, província de São Paulo) (Figura 10). Fundada em fins do século XVIII, a sede, composta por terreiros, engenhos, senzalas e casa de vivenda, foi finalizada por Luciano José de Almeida - então seu proprietário - na década de 18405. Em inventário de 1854, além da listagem de 815 escravos, dos quais mais da metade residia na Boa Vista, há referência à existência de dois conjuntos de senzalas em quadra. Por uma pintura oitocentista da fazenda, percebe-se claramente qual a disposição delas. A primeira localizava-se em frente à casa de vivenda, e era composta por sessenta lanços de senzalas mais tulhas e um engenho de pilões, ambos assentados em um único edifício disposto na parte superior direita do terreiro. A segunda quadra, apenas com os quarenta e nove lanços de senzalas, encontrava-se atrás. Na quadra frontal, nota-se a existência de um único portão de entrada; todas as portas dos lanços da senzala, por sua vez, voltavam-se para o terreiro. A planta seguia claramente o partido em U proposto por Palladio, cujo eixo era dado pela casa de vivenda.

O segundo exemplo, ainda que não tenha obedecido a esse plano palladiano, acompanhou as demais soluções da Boa Vista. Trata-se da fazenda do Retiro, de Paraíba do Sul (atual Bemposta, Rio de Janeiro), uma das inúmeras propriedades do clã dos Werneck (TAUNAY, 1939, p. 8, 329). Como documento para essa fazenda, temos um óleo pintado por Georg Grimm em 1881 (Figura 26). Nele, observa-se a presença de dois terreiros de café, um fora do risco da sede, outro disposto no interior da quadra que abrigava os cubículos dos escravos, as habitações do feitor, a tulha e o engenho. Seguiu-se, aqui, o típico padrão vale-paraibano da senzala em quadra: isolamento em relação ao espaço externo à fazenda, garantido por meio de sua disposição retangular, pelos compartimentos de habitação dos cativos que se comunicavam apenas com o terreiro, pela inexistência de janelas, pelos muros altos e pela entrada única fechada com portão. Uma de suas faces, além do mais, era parcialmente preenchida pelo volume do sobrado senhorial. Em fotos atuais da fazenda (Figura 27), vê-se que a parte do pavimento inferior que se conectava com o quadrado era reservada às dependências de serviço da casa de vivenda, havendo ainda, nesta face, uma capela em pé-direito duplo (Figura 28), com acesso independente fora do muro - a última porta do rés-do-chão. Em sua fachada, a casa-grande se 


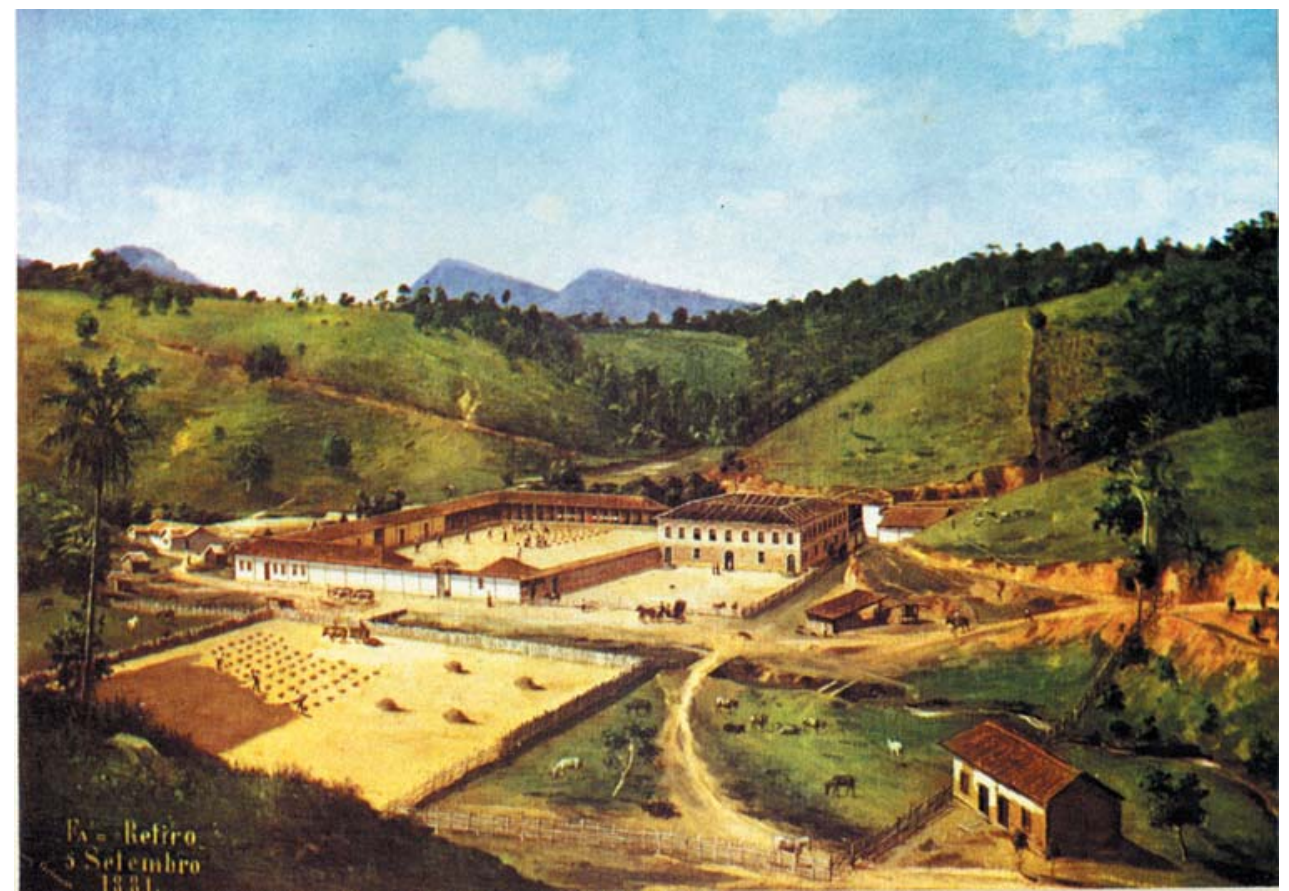

Figura 26 - Georg Grimm, Fazenda Retiro, 1881, óleo sobre tela. Coleção particular.

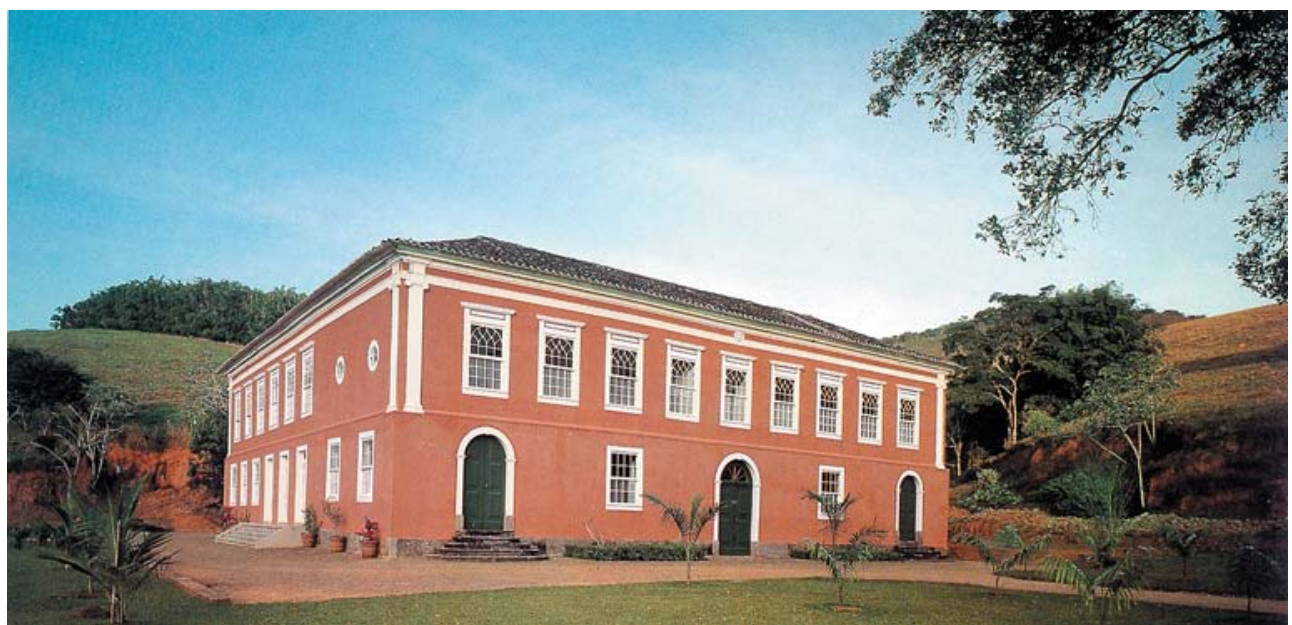

Figura 27 - Casa de vivenda da fazenda Retiro, fotografia de Pedro Osvaldo Cruz (PIRES, 1990, p. 126).

apropriava de parte do vocabulário neoclássico, como se observa na composição ordenada, no entablamento adotado, na moldura e pestana das janelas ou nos capitéis das pilastras dos cunhais. E, tal como na Boa Vista, todo o conjunto regia-se por uma integração estreita entre moradia escrava e moradia senhorial.

$\bigcirc$ último exemplo é, certamente, o mais grandioso. A fazenda Flores do Paraíso (Figura 29) foi construída em meados do século XIX no coração da 


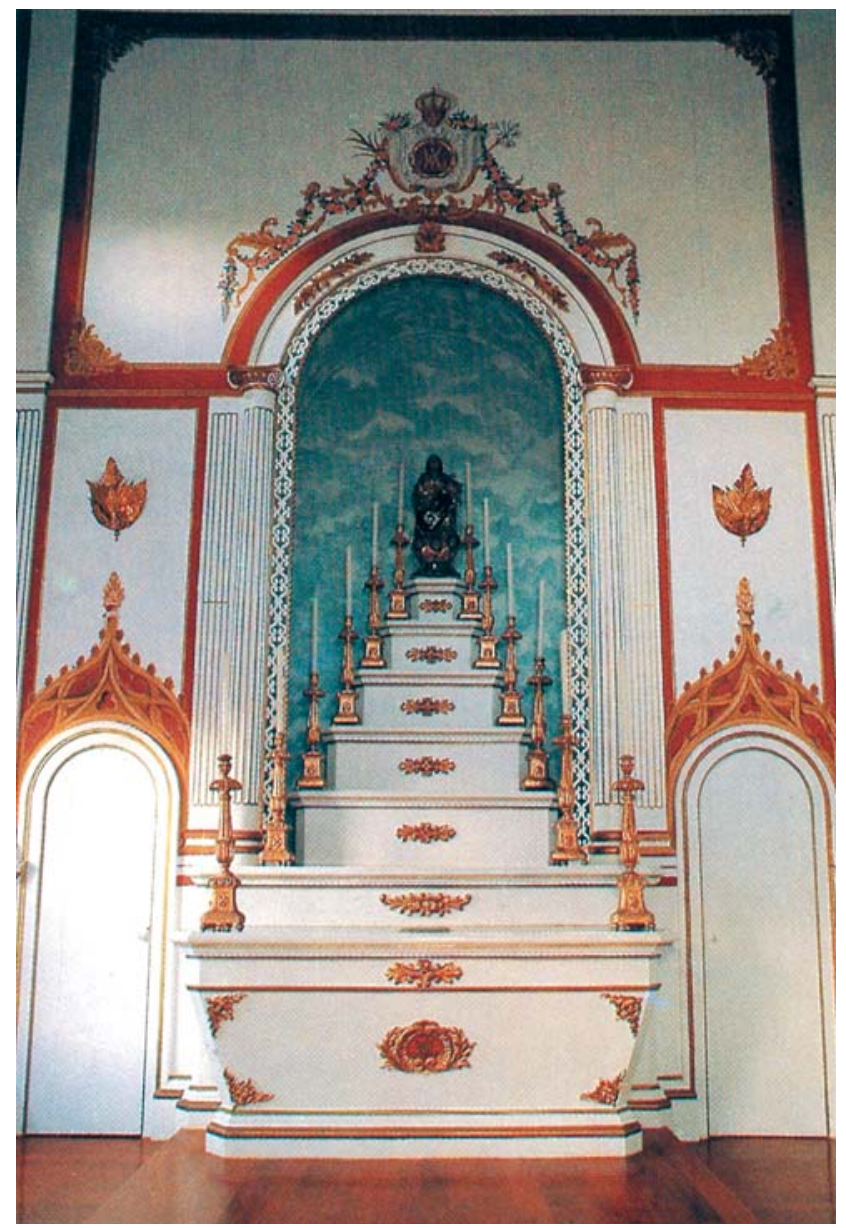

Figura 28 - Interior da capela da fazenda Retiro, fotografia de Pedro Osvaldo Cruz (PIRES, 1990, p. 126).

cafeicultura fluminense, no então município de Valença. Seu proprietário era Domingos Custódio Guimarães, nascido em São João del Rei em 1800, barão em 1854 e visconde do Rio Preto em 1867. A origem da fortuna de Custódio Guimarães datava da década de 1820, quando, em sociedade com o também mineiro José Francisco de Mesquita, fundou a companhia Mesquita \& Guimarães, especializada no abastecimento de carne para a Corte Imperial e na venda de escravos africanos serra acima (LENHARO, 1993, p. 62; TAUNAY, 1939, p. 5, 183-184). Na década seguinte, inverteu seus capitais, acumulados no comércio e no tráfico, na compra de terras e no plantio de café na região do vale do rio Preto (afluente do Paraíba), divisa das províncias do Rio de Janeiro e de Minas Gerais. O centro de suas atividades foi a sesmaria das Flores, adquirida em 1843, onde levantou a sede da Flores do Paraíso, finalizada dez anos depois (MUNIZ, 1979, p. 80-85; ALEGRIO, 2004, p. 33). Conhecida como a "jóia de Valença", a fazenda notabilizou-se pela adoção de uma série de inovações técnicas, como iluminação a gás, terreiros asfaltados e um avançado 


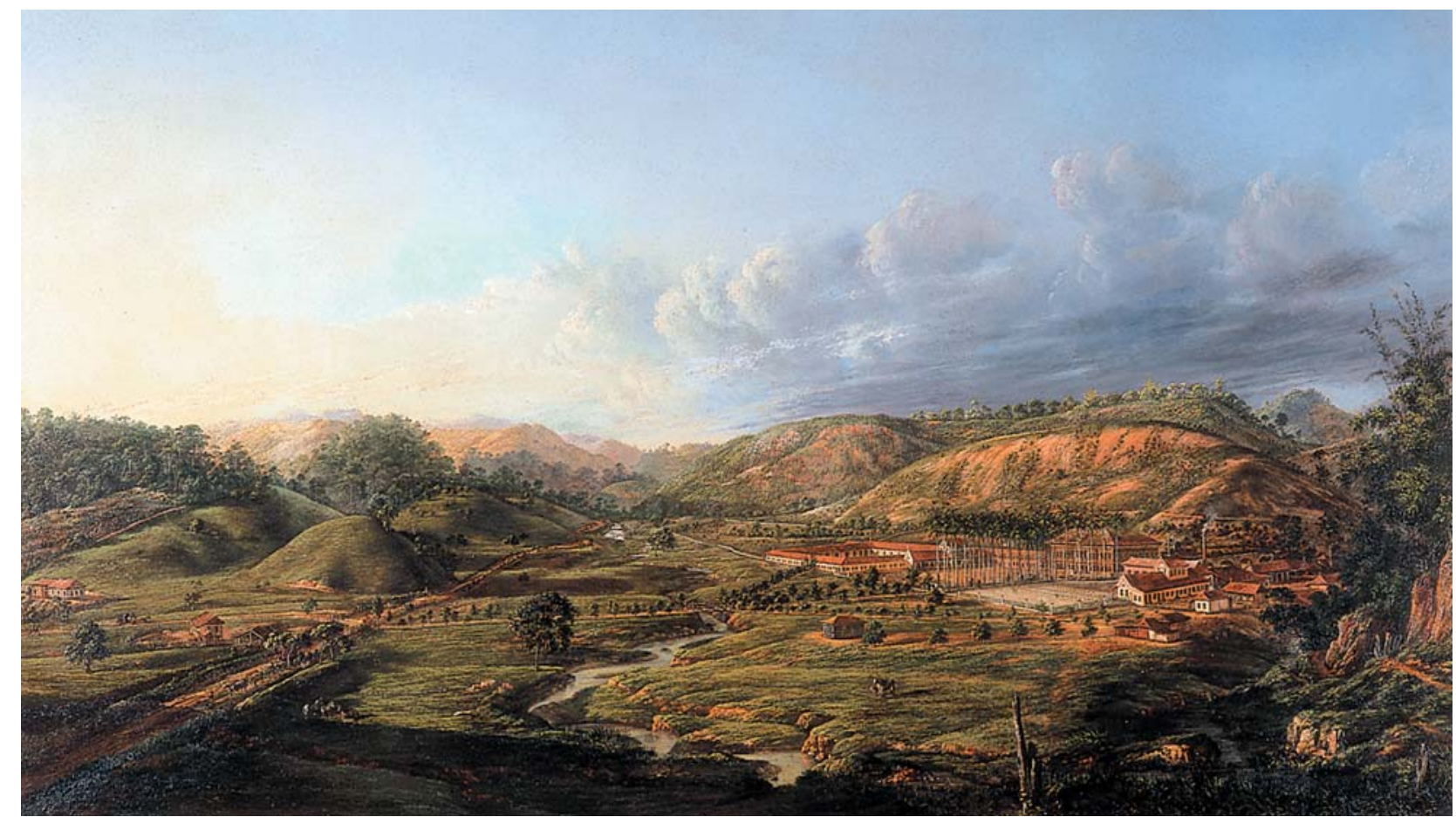

Figura 29 - Nicolau Facchinetti, Fazenda Flores do Paraíso, 1875, óleo sobre madeira. Coleção particular (MARTINS; PICCOLI, 2004, p. 16).

maquinário de beneficiamento cafeeiro implantado no início da década de 1860. Afora tudo isso, em 1875 a fazenda foi registrada pelo pincel de Nicolau Facchinetti, em uma das mais belas paisagens desse pintor italiano (MARTINS; PICCOLI, 2004).

que nos interessa é a sua planta. A via de acesso, que já no século XIX contava com a alameda de palmeiras imperiais ainda hoje existente, conduzia diretamente ao vão central da casa de vivenda. Com feições de palacete urbano, suas três portas da entrada eram encimadas por arcos plenos com bandeiras de ferro, em uma composição bem ao gosto do estilo neoclássico corrente na Corte Imperial (Figuras 30, 31 e 32). $\bigcirc$ partido palladiano em $U$ - preenchido pelos dois terreiros de café - era obtido por meio dos edifícios voltados ao processo produtivo e à morada dos trabalhadores. Assim, em seu braço esquerdo, estavam dispostas a casa do engenho e a tulha (Figura 9). $\bigcirc$ braço direito, por sua vez, era ocupado pela grande enfermaria da propriedade (Figura 33) e pela morada dos trabalhadores cativos. Neste ponto, Palladio se encontrava com o tráfico negreiro transatlântico: acoplada à ala direita, estava a enorme senzala em quadra da Flores do Paraíso (Figura 34). Quando do falecimento do Visconde do Rio Preto, em 1868, residiam aí cerca de 540 escravos, o que a aproximava dos maiores barracões de Cuba. No entanto, ao contrário da colônia espanhola, o contato visual entre moradia escrava e moradia senhorial era muito próximo (Figuras 35 e 36). 


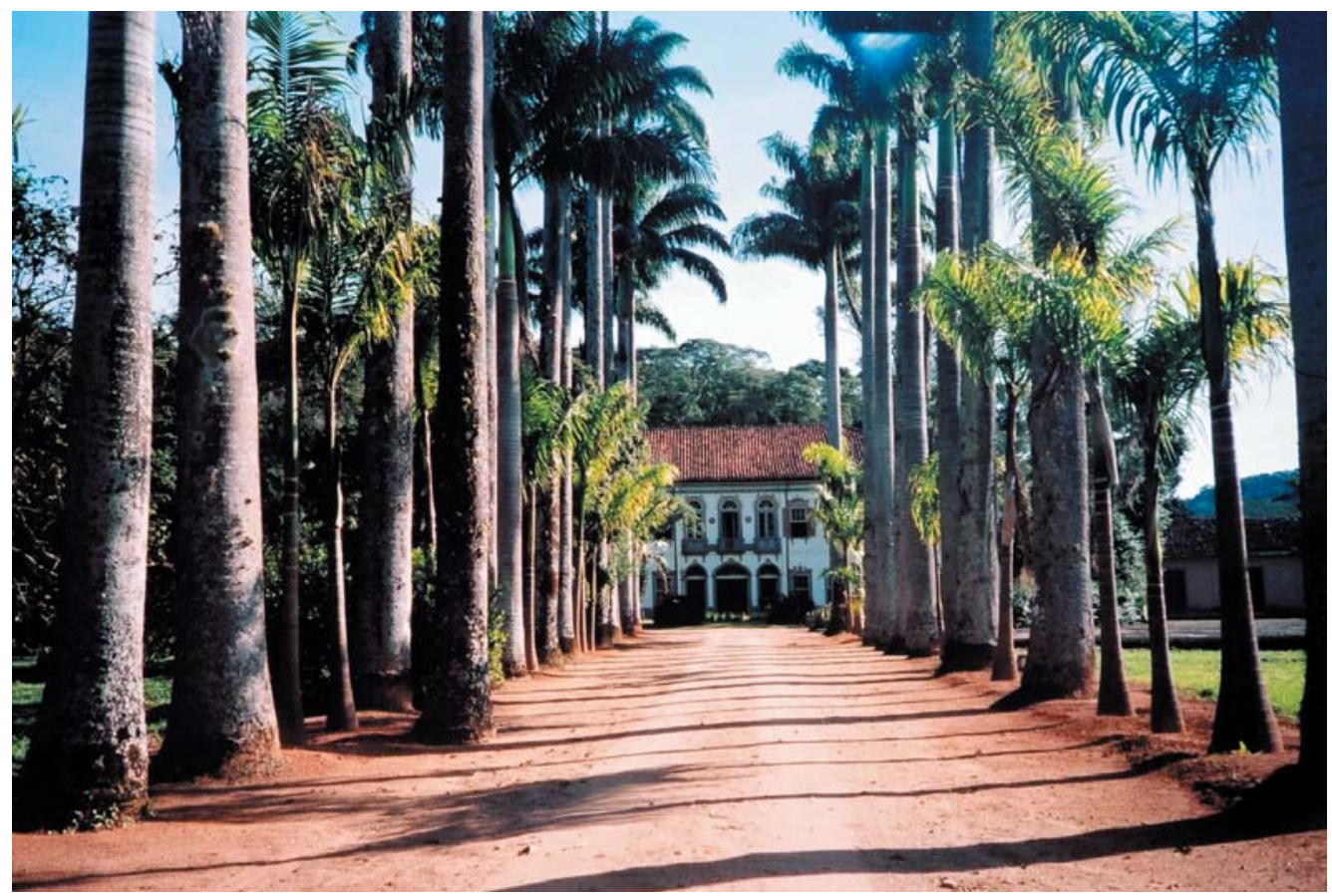

Figura 30 - Entrada da fazenda Flores do Paraíso, Rio das Flores, RJ, julho de 2005, fotografia de Ana Paula Gomes Marquese.

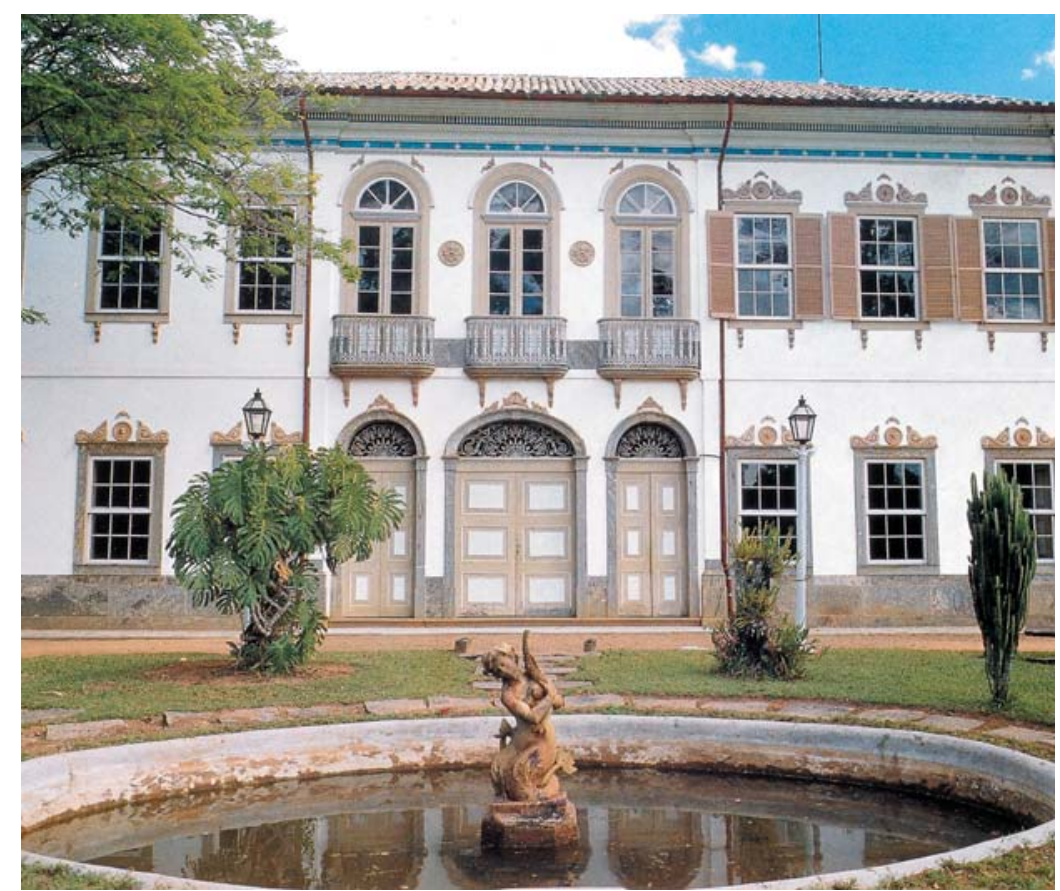

Figura 31 -Vista frontal da casa de vivenda da fazenda Flores do Paraíso, fotografia de Pedro Osvaldo Cruz (PIRES, 1990, p. 67). 


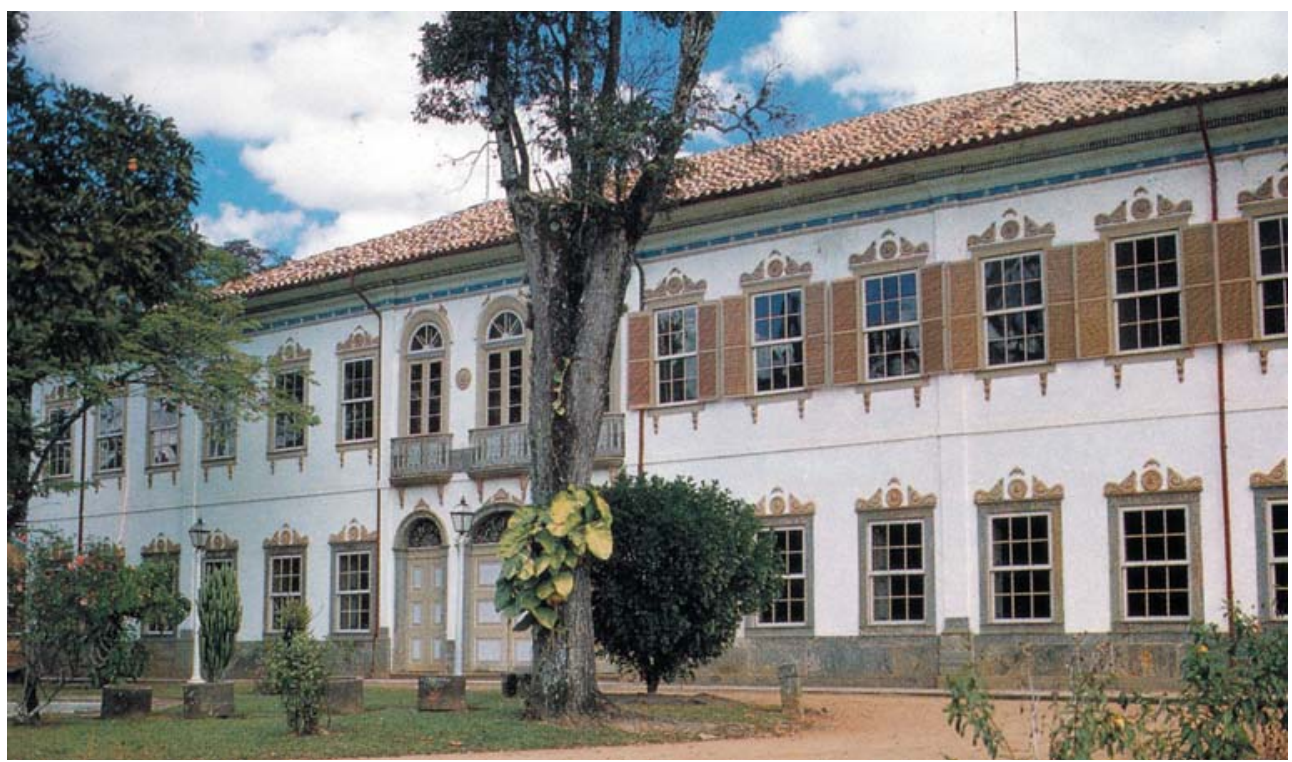

Figura 32 - Visão oblíqua da casa de vivenda da fazenda Flores do Paraíso, fotografia de Pedro Osvaldo Cruz (PIRES, 1990, p.67).

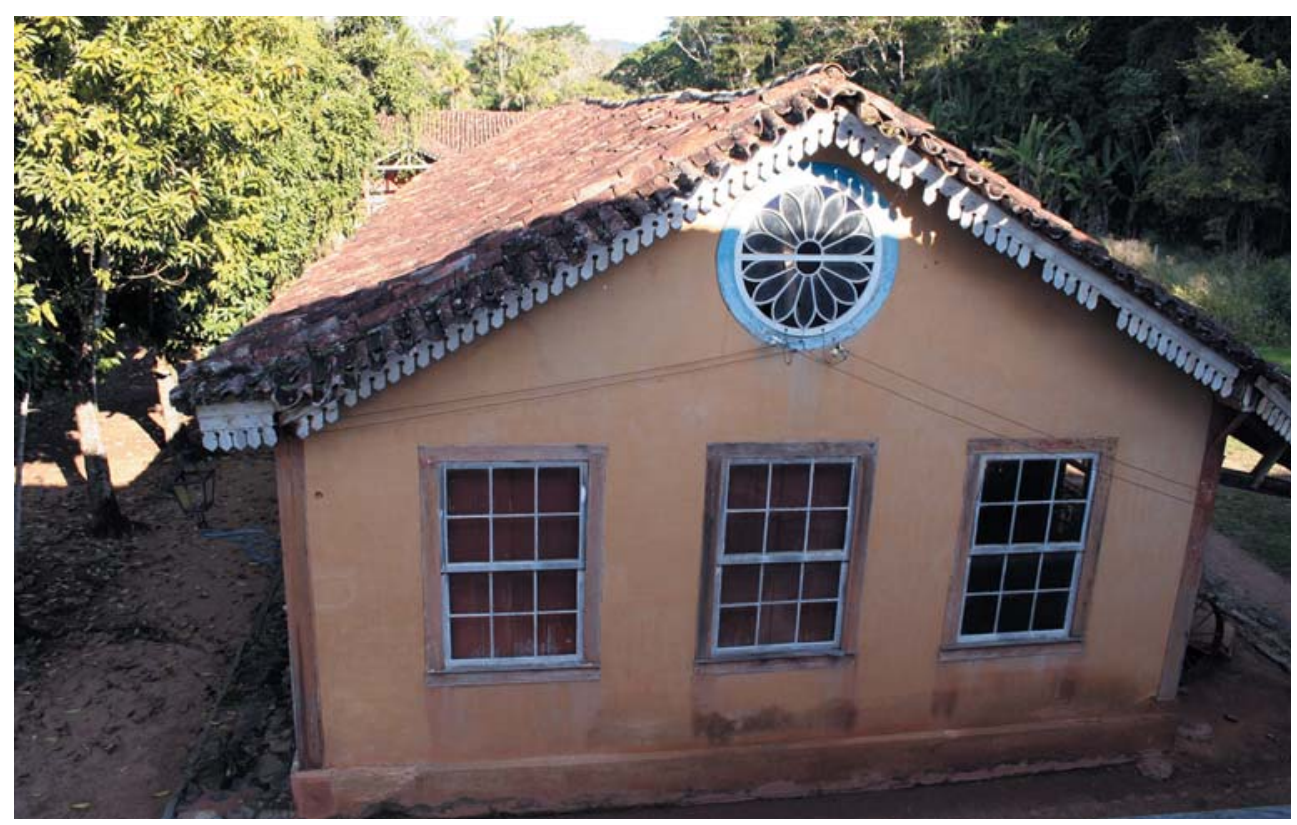

Figura 33 - Enfermaria da fazenda Flores do Paraíso, Rio das Flores, RJ, julho de 2005, fotografia de Maria Cecília Winter. 


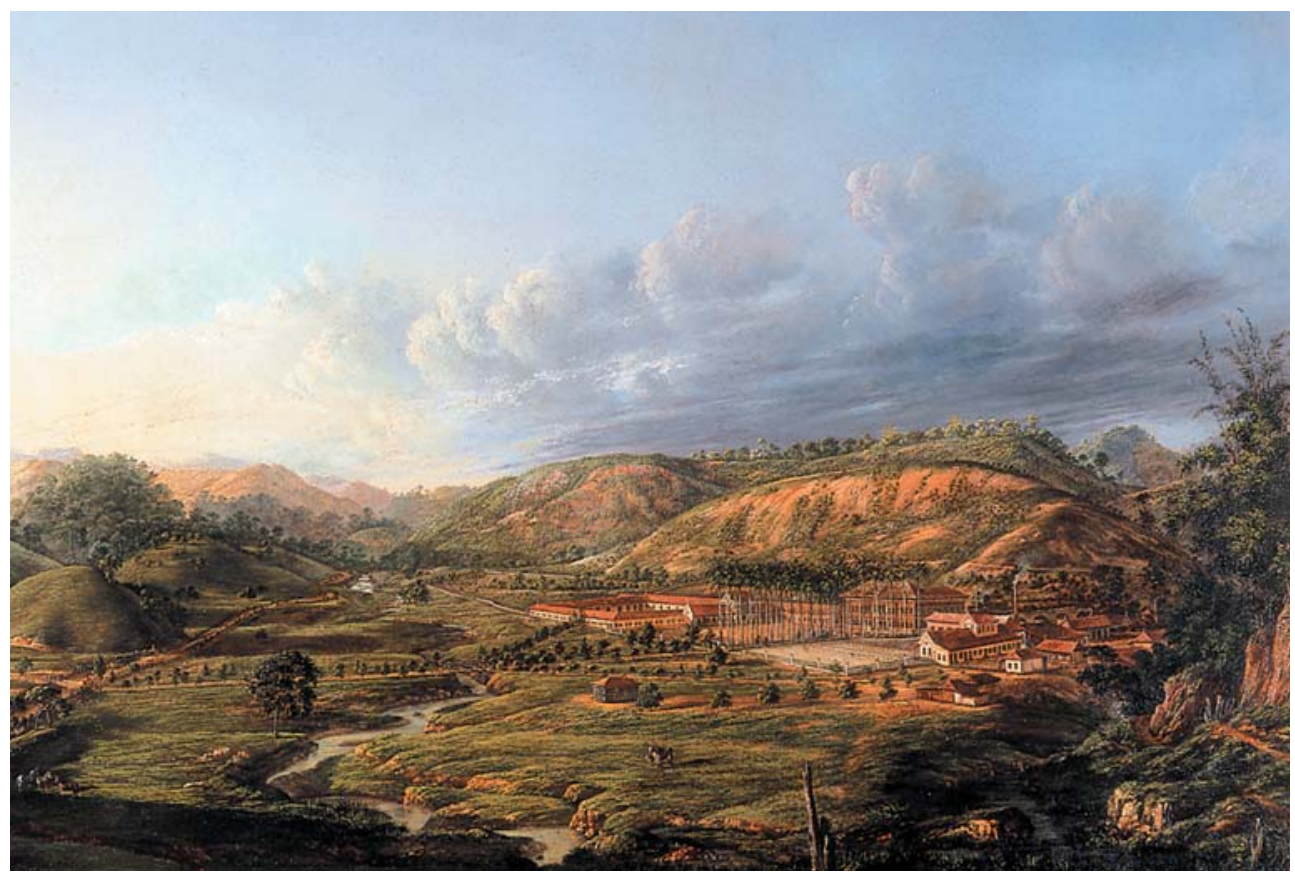

Figura 34 - Senzala em quadra à esquerda. Nicolau Facchinetti, Fazenda Flores do Paraíso (detalhe), 1875, óleo sobre madeira. Coleção particular (MARTINS; PICCOLI, 2004, p. 16).

Sendo assim, as fazendas do Vale do Paraíba combinaram alguns elementos presentes nas grandes plantations do sul dos Estados Unidos - como as casas de vivenda monumentais que se destacavam no conjunto das edificações - com outros dos engenhos mecanizados cubanos - como os enormes barracões destinados ao confinamento rigoroso da escravaria. E, destoando de ambos, avizinharam de modo estreito casa-grande e senzala.

A explicação para essa especificidade, uma vez mais, deve ser buscada no quadro social e político mais amplo. Para o exercício do poder pela classe senhorial escravista, no Império Constitucional do Brasil ltal como no sul dos Estados Unidos), o jogo eleitoral teve importância decisiva. Por aqui, todavia, esse jogo foi, desde a Regência (1831-1840), mediado por relações de clientelismo que atavam em redes assimétricas verticais todos os atores políticos envolvidos, dos membros do gabinete ministerial aos eleitores de paróquia. Para exercer o mando no nível do município e, por vezes, da província, os grandes senhores precisavam se apresentar como patriarcas capazes de obter a deferência de seus clientes (aliados políticos, parentes, agregados e demais dependentes), garantindo-thes, em troca, proteção e espaço para se inserirem positivamente nas hierarquias locais (FRANCO, 1983; MATTOS, 1987; GRAHAM, 1997).

No Vale do Paraíba fluminense (eixo Cantagalo-Resende) e no fundo do Vale paulista (eixo Bananal-Lorena), onde, como parte do movimento de formação da zona cafeeira, quase todas as vilas e cidades foram criadas após a independência, as grandes sedes das fazendas assumiram papel relevante na 


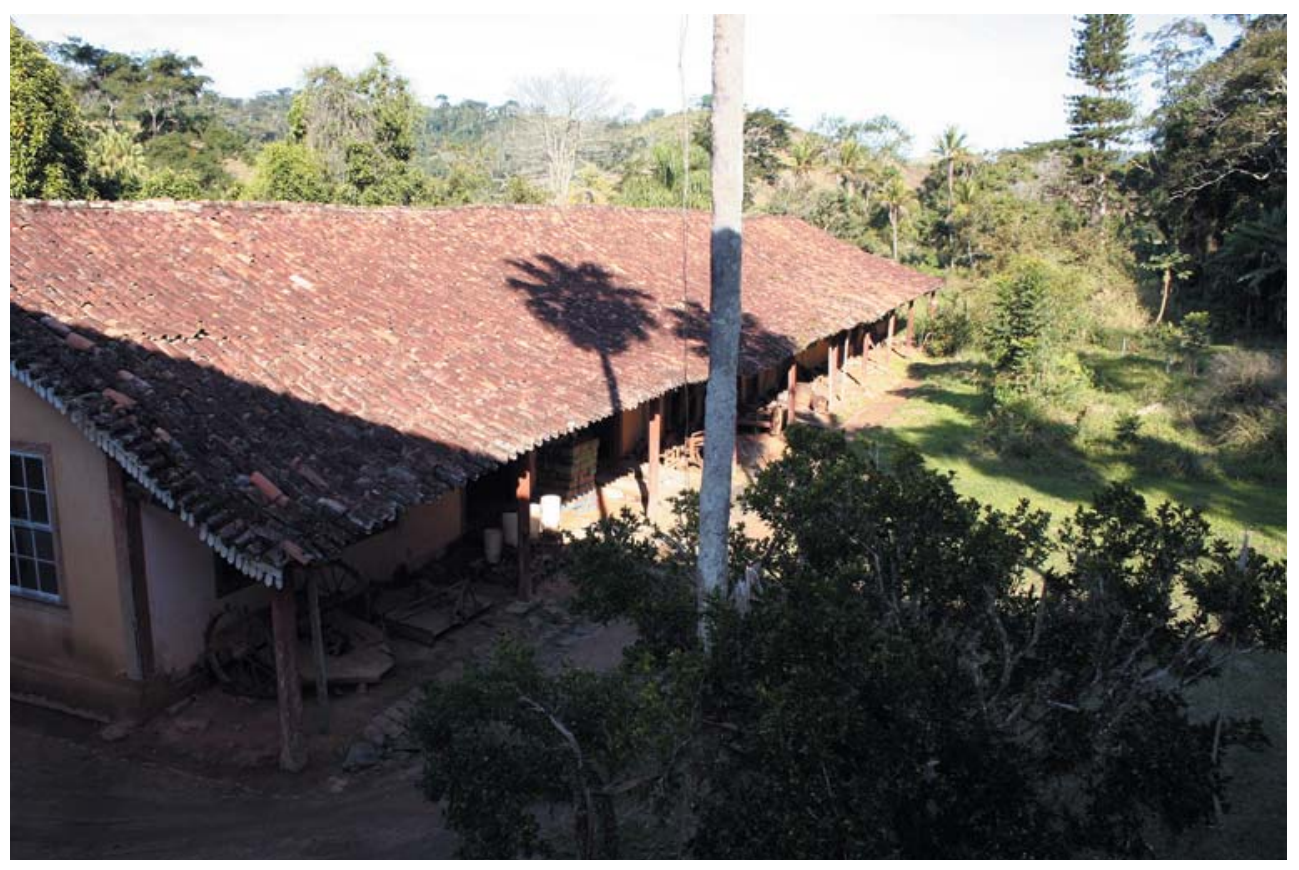

Figura 35 - Fundos da enfermaria da fazenda Flores do Paraíso, Rio das Flores, RJ, julho de 2005, fotografia de Maria Cecília Winter.

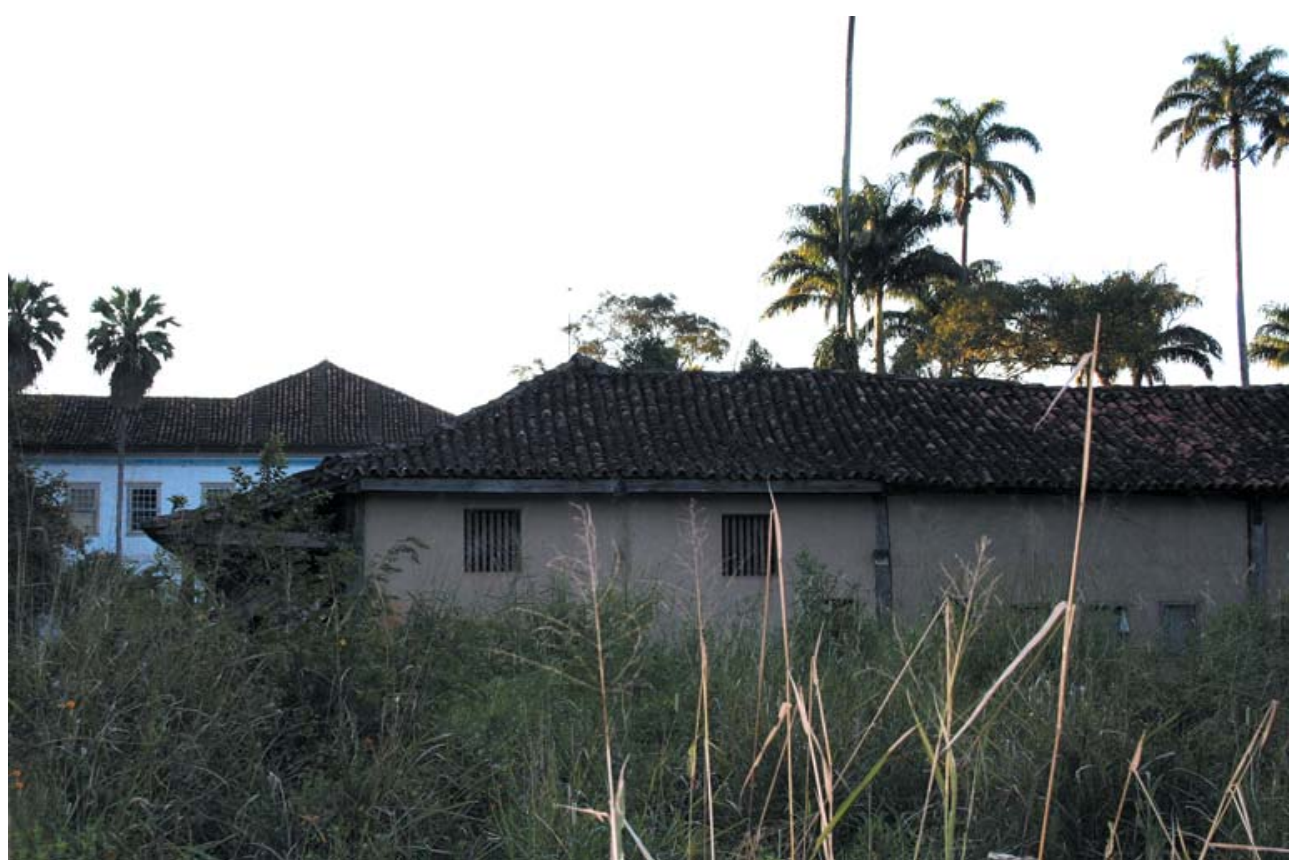

Figura 36 - Vista da casa de vivenda tomada do interior da quadra da senzala, fazenda Flores do Paraíso, Rio das Flores, RJ, julho de 2005, fotografia de Maria Cecília Winter. 
política calcada em práticas clientelistas. As casas de vivenda monumentais, somadas aos terreiros, instalações produtivas e senzalas dispostas em quadra, constituíam um conjunto arquitetônico com uma enorme carga de representação. As imagens elaboradas pelos viajantes europeus que percorreram o Vale são bastante esclarecedoras quanto a isso. Veja-se, por exemplo, o relato de Augusto Zaluar, que, em setembro de 1859, visitou a fazenda do Ribeirão Frio, município de Piraí:

\begin{abstract}
Assentada no meio de uma vasta planície, circundada por um horizonte de montanhas cujo recorte se desenha com facilidade, a casa espaçosa e branca avulta dentro de um terreiro de trezentas e onze braças de circunferência! É o maior que tenho visto. Esta imensa praça é fechada em torno pelas senzalas, engenho e mais oficinas, de modo que forma uma larga cidadela para onde se entra por dois grandes portões laterais. As senzalas, caiadas todas e construídas uniformemente, destacam-se, bem como a casa, do verde graduado das florestas, e dão a esta propriedade um aspecto novo e agradável. [...] Uma propriedade rural montada no pé em que se acha, o Ribeirão Frio é mais do que um prédio de simples vivenda; é uma cidade em ponto pequeno, onde se cultivam muitos ramos de indústria e se põem em movimento todas as gradações do trabalho (ZALUAR, 1975, p. 29).
\end{abstract}

Essas "cidades em ponto pequeno" - imagem que derivava diretamente de Alberti e Palladio (BENTMANN; MÜLLER, 1975, p. 51-52) - funcionavam, ao fim e ao cabo, como um dos principais vetores do poder social e político de seus senhores sobre as comunidades locais. A associação visual que os proprietários pretendiam estabelecer entre suas fazendas e a cidade do Rio de Janeiro - por meio de alamedas de palmeiras imperiais ou de pinturas murais, como a da sala de jantar da Flores do Paraíso (Figura 37) - operava dentro

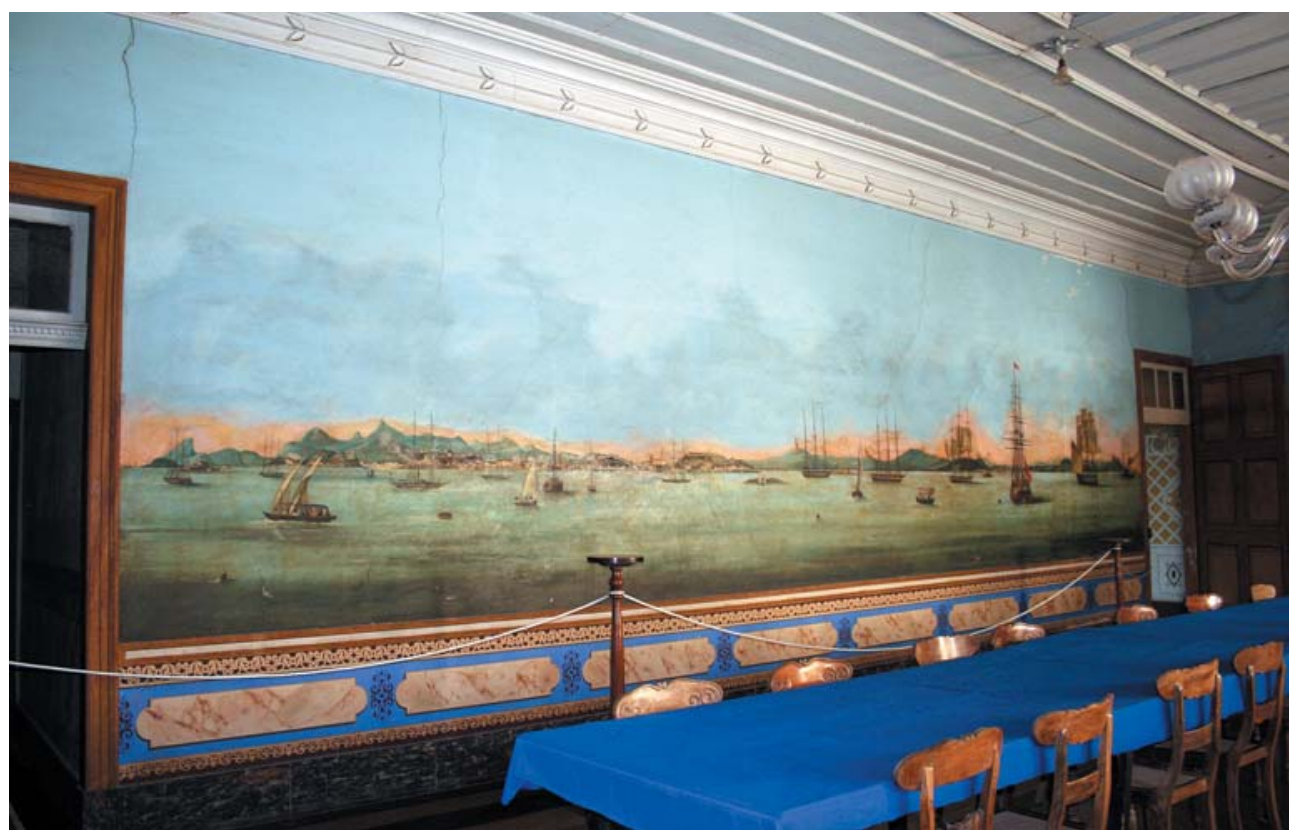

Figura 37 - [José Maria Villaronga], Pintura mural da sala de jantar da fazenda Flores do Paraíso, Rio das Flores, RJ, julho de 2005, fotografia de Maria Cecília Winter. 
dessa mesma lógica. A mensagem a se transmitir era a de que a fazenda não representava uma cidade qualquer, mas nada mais nada menos do que a própria Corte Imperial (REIS FILHO, 2004, p. 122-124). Não por acaso, a primeira onda de construção das vivendas monumentais no Vale do Paraíba coincidiu exatamente com a primeira leva de títulos nobiliárquicos concedidos por D.Pedro Il aos potentados cafeeiros (STEIN, 1990; PANG, 1988).

Resta entender o confinamento dos escravos nas senzalas em quadra e sua posição contígua às casas-grandes. A chave para tanto se encontra na teoria coeva da gestão escravista. As razões que levaram os produtores de café do Vale do Paraíba a adotarem tal arranjo arquitetônico foram as mesmas que motivaram os sacarocratas cubanos a transplantarem pelo Atlântico o modelo dos barracões de embarque de cativos da Costa d'África. Ambas as classes senhoriais, que tinham conexões estreitas com os traficantes que operavam na ilegalidade, pretendiam, com isso, aumentar o controle sobre uma escravaria majoritariamente africana em um contexto de sobreexploração do trabalho e de incremento da resistência cativa (MARQUESE, 2005).

No Império do Brasil, contudo, o modelo do barracão teve de se ajustar ao paternalismo que informava os valores ideológicos senhoriais. As fazendas vale-paraibanas foram uma clara manifestação disso: os escravos eram entendidos como parte da família extensa ou mesmo como prolongamento físico de seus senhores e, por essa razão, cabia aproximar as quadras das senzalas das casas de vivenda. Mas, como se viu em item anterior, no sul dos Estados Unidos, onde as relações escravistas também foram apreendidas pela grade do paternalismo, os casebres escravos ficavam distantes das casas-grandes. Voltamos, aqui, ao clientelismo. Por conta da dinâmica da alforria e da contínua produção de dependentes, algo evidente na paisagem cafeeira, com o avultado número de sítios e fazendolas que rodeavam as grandes unidades e que não raro pertenciam a grupos sociais egressos do cativeiro (LÄ̈RNE, 1885, p. 278), os escravos eram concebidos como participantes da clientela de seus senhores.

Tal concepção encontrou expressão em uma componente importante da arquitetura das fazendas de café que, em geral, passa despercebida aos especialistas. Refiro-me às capelas, invariavelmente inscritas no corpo da casa de vivenda e sempre voltadas para o lado das senzalas (Figuras 38 e 39). 0 pé-direito duplo de muitas delas traduzia, por si só, a hierarquia e o poder que regiam as relações escravistas, já que o acesso ao balcão superior era restrito à família branca, enquanto o acesso ao piso térreo, onde ficavam os escravos, era feito por uma entrada independente. Cabe lembrar, todavia, que nessas capelas eram realizados batismos e casamentos não apenas da escravaria pertencente ao dono da fazenda, mas igualmente dos cativos de seus vizinhos. Com isso, multiplicavam-se as hierarquias: pequenos proprietários que levavam seus escravos para serem batizados em capelas de grandes fazendas/senhores que os recebiam; senhores que promoviam casamentos e batismos de seus escravos/conjunto da escravaria; os que ficavam no andar superior/os que ficavam no inferior. As capelas, enfim, não só expressavam as redes de clientelismo que cortavam de cima a baixo a sociedade escravista no Vale do Paraíba, como 


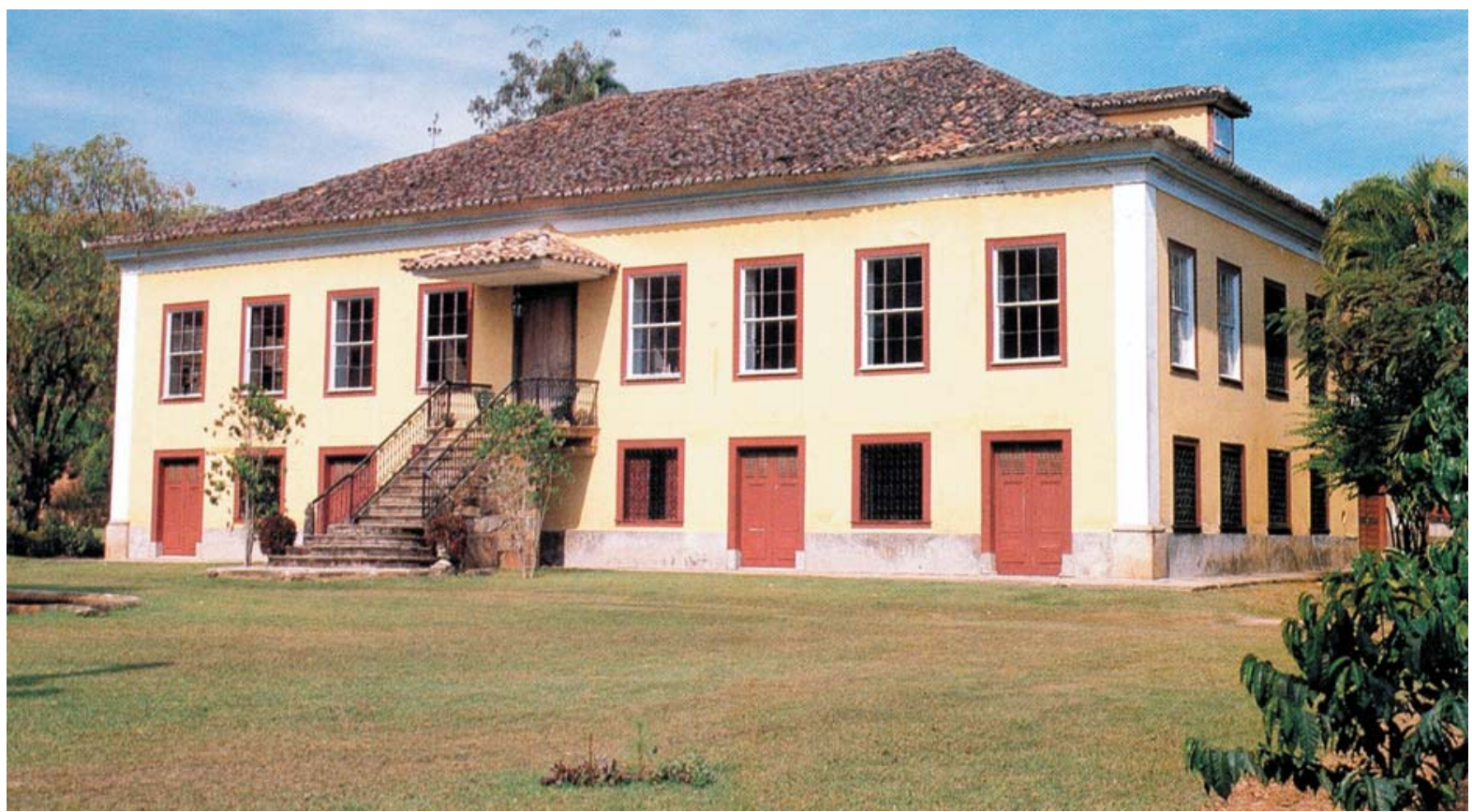

Figura 38 - Vista oblíqua da casa de vivenda da fazenda Resgate, Bananal, SP, fotografia de Pedro Osvaldo Cruz (PIRES, 1990, p. 83).

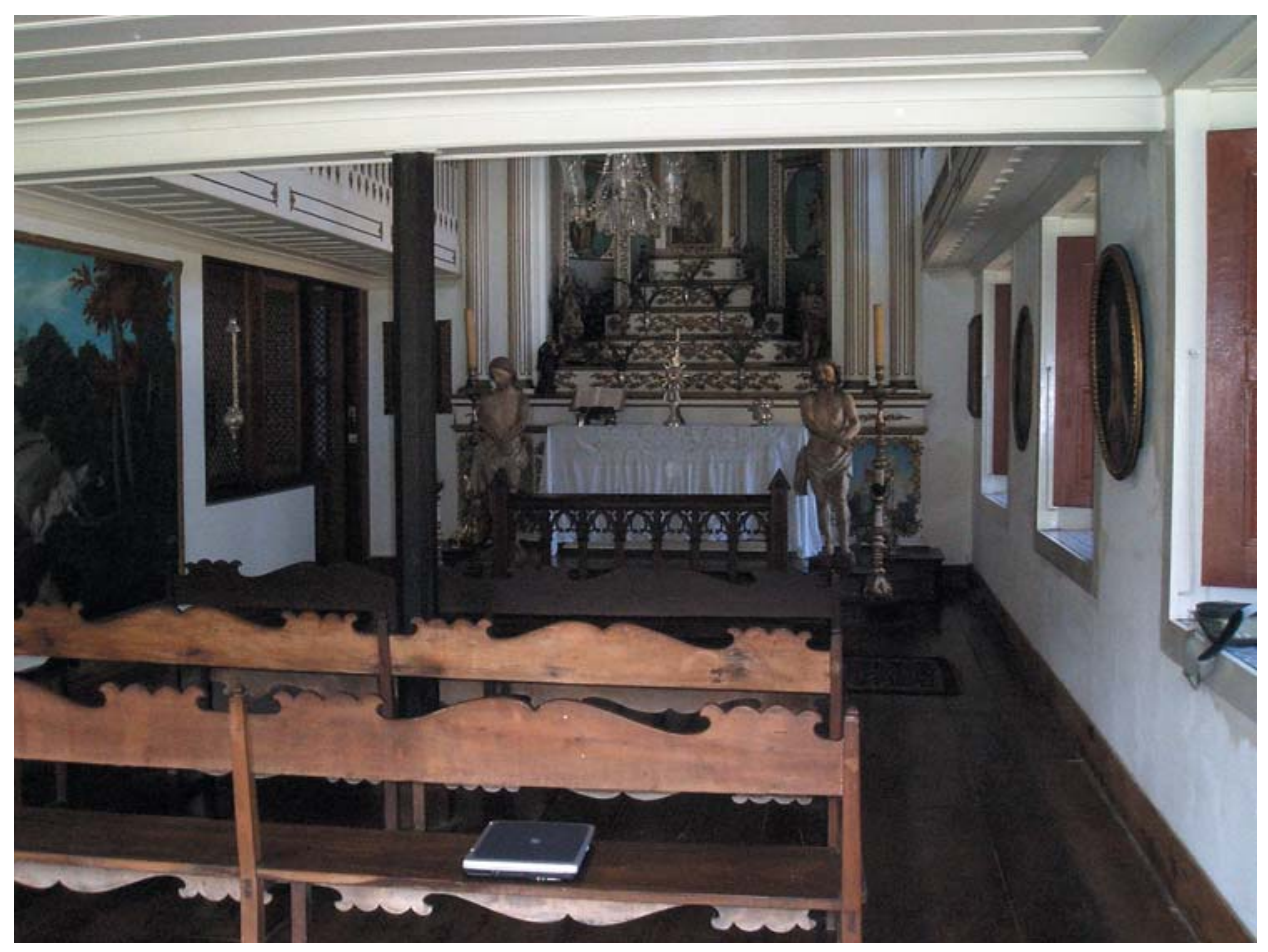

Figura 39 - Interior da capela da fazenda Resgate, Bananal, SP, maio de 2005, fotografia de Rafael de Bivar Marquese. 
também funcionavam como vetores na criação de novas relações sociais, de resto algo válido para todo ambiente construído das plantations escravistas do Novo Mundo. Isto, no entanto, é assunto para outro texto.

\section{REFERÊNCIAS}

ACKERMAN, J. S. The Villa: form and ideology of country houses. Princeton, N.J.: Princeton University Press, 1990.

AGUIAR, Pe. J.J. F. de. Pequena memória sobre a plantação, cultura e colbeita do café. Rio de Janeiro: Imprensa Americana de I. P.da Costa, 1836.

AIKEN, C. S.The evolution of cotton ginning in the Southeastern United States. Geographical Review, v. 62, n. 2, p. 196-224,April 1973.

ALEGRIO, L.V. Janelas e portas do café:Vale do Paraíba fluminense. Rio de Janeiro: SESC-RJ, 2004.

ASHWORTH, J. Slavery, capitalism and politics in the Antebellum Republic: commerce and compromise, 1820-1850. v. 1. Cambridge: Cambridge University Press, 1995.

BENTMANN, R.; MÜLLER, M.La Villa como arquitectura del Poder.Tradução Espanhola. Barcelona: Barral, 1975.

BERBEL, M.; MARQUESE, R. B. A escravidão nas experiências constitucionais ibéricas, 1810-1824. In: Seminário Internacional Brasil, de um Império a Outro (1750-1850). São Paulo: Departamento de História, Faculdade de Filosofia, Letras e Ciências Humanas, Universidade de São Paulo, 2005.

BERLIN, I. Many thousands gone: the first two centuries of slavery in North America. Cambridge, Mass.: Belknap, 1998.

CANTERO, J.; LAPLANTE, E. Los Ingenios: colección de vistas de los principales ingenios de azúcar de la Isla de Cuba. Havana: Impr. Lit. Luís Marquier, 1857.

CARANDINI,A. (Ed.) Settefinestre: una villa schiavistica nell'Etruria romana. v.1. Modena: Panini, 1984, p. $198.3 \mathrm{v}$.

CARRILHO, M. J. As fazendas de café no Caminbo Novo da Piedade. Dissertação (Mestrado em Arquitetura)-Faculdade de Arquitetura e Urbanismo, Universidade de São Paulo, São Paulo, 1994.

CASTRO, A. B. Escravos e senbores nos engenbos do Brasil. Tese (Doutorado em Economia)-Instituto de Economia, Universidade Estadual de Campinas, 1976. 
CHAPLIN, J. An anxious pursuit: agricultural innovation \& modernity in the Lower South, 17301815. Chapel Hill: University of North Carolina Press, 1993.

COOPER JR., W. Liberty and slavery: southern politics to 1860. Columbia: University of South Carolina Press, 2000.

COSTA, L. A arquitetura dos jesuítas no Brasil. Revista do Serviço do Patrimônio Histórico e Artístico Nacional, n. 5, p. 9-100, 1941.

DALZELL JR., R. F. Constructing Independence: Monticello, Mount Vernon, and the men who built them.Eighteenth-Century Studies, vol. 26, n. 4, p. 543-580, Summer 1993.

DIDEROT; D. (Ed.). Encyclopédie, ou diccionnaire raisonné des sciences, des arts et des métiers (1751-1766). New York: 1969

EPPERSON,T. Constructing difference: the social and spatial order of the Chesapeake plantation. In: SINGLETON,T. (Ed.). "I, Too, An America”: Archeological Studies of African-American Life. Charlottesville: University Press of Virginia, 1999.

FARIA, S. S. C. Fortuna e família em Bananal no século XIX. In: CASTRO, Hebe Maria Mattos de; SCHNOOR, Eduardo (Org.). Resgate: uma janela para o oitocentos. Rio de Janeiro:Topbooks, 1995.

FRADERA, J. Gobernar colonias. Barcelona: Península, 1999.

FRAGINALS, M. M. O engenbo: complexo sócio-econômico açucareiro cubano. Tradução Sônia Rangel; Rosemary C.Abílio. São Paulo: Hucitec; Editora da Unesp, 1987, 2v.

FRANCO, M. S. C. Homens livres na ordem escravocrata. 3. ed. São Paulo: Kairós, 1983.

GAMA, R. Engenbo e tecnologia. São Paulo: Duas Cidades, 1983.

GARCÍA,A.; ZANETTI, O. Sugar and Railroads. A Cuban History, 1837-1959. Tradução Franklin Knight \& Mary Todd. Chapel Hill:The University of North Carolina Press, 1998.

GENOVESE, E. Roll, Jordan, roll: the world the slaves made. New York:Vintage, 1974.

GLEASON, D. K. Plantation Homes of Louisiana and the Natchez Area. Baton Rouge: Louisiana State University Press, 1982.

GRAHAM, R. Clientelismo e política no Brasil do século XIX. Tradução Celina Brandt. Rio de Janeiro: Editora de Universidade Federal do Rio de Janeiro, 1997.

GRAY, L. W. History of Agriculture in the Southern United States to 1860. Gloucester: Peter Smith, 1958. 2v. (1 $1^{\mathbf{a}}$ ed.:1933).

GUARINELLO, N. L. Ruínas de uma paisagem: arqueologia das casas de fazenda da Itália antiga (VIII a.C.-II d.C.). Tese (Doutorado em Antropologia Social)-Departamento de Antropologia, Faculdade de Filosofia, Letras e Ciências Humanas, Universidade de São Paulo, São Paulo, 1993. 
HARRIS, D. S. The nature of authority: villa culture, landscape, and representation in eighteenthcentury Lombardy. University Park, Penn.: Penn State, 2003.

HOBSBAWM, E.; RANGER,T.(Org.). A invenção das tradições. Tradução Celina Cardim Cavalcante. Rio de Janeiro: Paz \& Terra, 1984.

LABORIE, P. J. The coffee planter of Saint Domingo. London: [s.n.], 1798.

LAËRNE, C. F. D. Brazil and Java: report on coffee-culture in America, Asia, and Africa. London: Martinus Nijhoff, 1885.

LEMOS, C. Casa paulista: história das moradias anteriores ao ecletismo trazido pelo café. São Paulo: Edusp, 1999.

LENHARO,A. As tropas da moderação: o abastecimento da Corte na formação política do Brasil, 1808-1842. 2. ed. Rio de Janeiro: Secretaria Municipal de Cultura e TE-Prefeitura da Cidade do Rio de Janeiro, 1993.

MARQUESE, R. B.Açúcar, representação visual e poder: a iconografia sobre a produção caribenha de açúcar nos séculos XVII e XVIII. Revista USP, n. 55, p. 152-184, set.- nov. 2002.

Feitores do corpo, missionários da mente: senhores, letrados e o controle dos escravos nas Américas, 1660-1860. São Paulo: Companhia das Letras, 2004.

Moradia escrava na era do tráfico ilegal: senzalas rurais no Brasil e em Cuba no século XIX. Anais do Museu Paulista: história e cultura material, São Paulo, Museu Paulista, Nova Série v. 13, n. 2, jul.-dez. 2005.

MARTINS, C.; PICCOLI, V. Facchinetti. Rio de Janeiro: Centro Cultural Banco do Brasil, 2004.

MARX, K. El Capital: crítica de la economía política. v. 1. Tradução Wenceslao Roces. México: Fondo de Cultura Económica, 1990.

MATTOS, I. R. O tempo saquarema: a formação do Estado imperial. São Paulo: Instituto Nacional do Livro; Hucitec, 1987.

MENESES, U.T. B. Morfologia das Cidades Brasileiras: introdução ao estudo da iconografia urbana. Revista USP. Dossiê Brasil dos Viajantes, n. 30, p. 144-155, jun.-ago. 1996.

MILLER, J. C. O Atlântico escravista: açúcar, escravos e engenhos. Afro-Ásia, n. 19-20, p. 9-36, 1997. Cuba / España, España / Cuba: Historia Común. Barcelona: Crítica, 1995.

MORGAN, E. American slavery, American freedom: the ordeal of colonial Virginia. New York: W.W. Norton, 1975.

MORGAN, P. Slave counterpoint: black culture in the eighteenth-century Chesapeake \& Lowcountry. Chapel Hill: University of North Carolina Press, 1998. 
MUNIZ, C. M. L. Os donos da terra: um estudo sobre a estrutura fundiária do Vale do Paraíba Fluminense, século XIX. Dissertação (Mestrado em História)-ICHF, Universidade Federal Fluminense, Niterói, 1979.

OAKES, J. Slavery and freedom: an interpretation of the Old South. New York:W.W. Norton, 1990.

PANG, E. In pursuit of honor and power: noblemen of the Southern Cross in nineteenth century Brazil.Tuscaloosa:The University of Alabama Press, 1988.

PARISH, P. Slavery: history and historians. New York: Harper \& Row, 1989.

PIRES, F. T. F. Fazendas: solares da região cafeeira do Brasil imperial. Rio de Janeiro: Nova Fronteira, 1990. Fotos de Pedro Osvaldo Cruz.

REIS FILHO, N. G. Quadro da arquitetura no Brasil. 10. ed. São Paulo: Perspectiva, 2004.

RODRIGUES, P. C. O caminho novo: povoadores do Bananal. São Paulo: Governo do Estado de São Paulo, 1980.

SCHMIDT-NOWARA, C. Empire and antislavery: Spain, Cuba, and Puerto Rico, 1833-1874. Pittsburgh: University of Pittsburgh Press, 1999.

SETUBAL, M.A. (Coord.). Modos de vida dos paulistas: identidades, famílias e espaços domésticos. São Paulo: Cenpec; Imprensa Oficial, 2004. (Coleção Terra Paulista: histórias, arte, costumes, V.2)

SITTERSON,J.C.(1953). Sugar country: the cane sugar industry in the South, 1753-1950. Westport, Conn.: Greenwood Press, 1973.

STEIN, S. J. Vassouras: um município brasileiro do café, 1850-1900. Tradução Vera Bloch Wrobel. Rio de Janeiro: Nova Fronteira, 1990.

TAUNAY,A. de E. História do café no Brasil. Rio de Janeiro: Departamento Nacional do Comércio, 1939. $15 \mathrm{v}$.

TOMICH, D. Through the prism of slavery: labor, capital, and world economy. Boulder, Co.: Rowman \& Littlefield, 2004.

Material process and industrial architecture: innovation on the Cuban sugar frontier, 1818-1857. In: CICCANTELL, Paul S.; SMITH, David A.; SEIDMAN, Gay (Ed.). Research in rural sociology and development: nature, raw materials, and political economy [Amsterdam], n. 10, p. 287-397, 2005a.

Between image and text:clues, documentation and representation of the Cuban Ingenio, 1820-1860.Texto apresentado ao Seminário Place, Event, and Narrative Craft: method and meaning in microhistory. Santa Fe, New Mexico: School of American Research, 2005b.

TORRES-CUEVAS, E. De la Ilustración reformista al Reformismo liberal. In: Historia de Cuba: La Colonia: evolución socioeconómico y formación nacional. La Habana: Política, 1994. 
VALVERDE, O.A fazenda de café escravocrata no Brasil.In:Estudos de geografia agrária brasileira. Petrópolis: Vozes, 1985.

VELLOSO, Frei J. M. C. (Org.). O fazendeiro do Brazil. Lisboa:Tip.Arco do Cego, 1798-1806. 11 v.

VENEGAS, C. El libro de los Ingenios. In: MALPICA CUELLO,Antonio (Ed.).Agua, trabajo y azúcar: actas del VI Seminario Internacional de Caña de Azúcar (Motril, 19-23 de septiembre de 1994). Granada: Diputación Provincial de Granada, 1996.

VLACH,J.M.Back of the big house: the architecture of plantation slavery. Chapel Hill:The University of North Carolina Press, 1993.

WALLERSTEIN,I.The modern world-system I:capitalist agriculture and the origins of the European world-economy in the sixteenth century. New York:Academic, 1974.

WATTS, D. Las Indias Occidentales: modalidades de desarrollo, cultura y cambio medioambiental desde 1492. Tradução Rosendo Gallego. Madrid:Alianza, 1992.

WERNECK, F. P. L. Memória sobre a fundação de uma fazenda na Província do Rio de Janeiro (1847). Organizador Eduardo Silva. Rio de Janeiro: Fundação Casa de Rui Barbosa; Senado Federal, 1985.

WHARTENBY, F. G. Land and labor productivity in United States cotton production, 18001840. New York:Arno, 1977.

WRIGHT, G. Political economy of the cotton south: households, markets, and wealth in the nineteenth century. New York:W.W. Norton, 1978.

ZALUAR, A. E. Peregrinação pela Província de São Paulo (1860-1861). Belo Horizonte: Itatiaia; São Paulo: Edusp, 1975.

Artigo apresentado em 11/2005. Aprovado em 04/2006. 